\title{
Development of Wear Resistant \\ Ceramic Coatings for Diesel \\ Engine Components
}

\author{
M. H. Haselkorn
}

Date Published-April 1992

\author{
Prepared by \\ Caterpillar, Inc. \\ Research Depariment \\ Technical Center \\ P. O. Box 1875 \\ Peoria, Illinois 61656-1875 \\ $86 \mathrm{X}-\mathrm{SA} 582 \mathrm{C}$
}

\author{
Funded by \\ Office of Transportation Materials \\ Office of Transportation Technologies \\ the Assistant Secretary for Conservation and Renewable Energy \\ U.S. Department of Energy \\ EE 5101000
}

\author{
for \\ OAK RIDGE NATIONAL LABORATORY \\ Cak Ridge, Tennessee 37831 \\ managed by \\ MARTIN MARIETTA ENER.GY SYSTEMS, INC. \\ for the \\ U.S. DEPARTMENT OF ENERGY \\ under Contract DE-AC05-84OR21400
}


1.0 Abstract

\section{TABLE OF CONTENTS}

2.0 Introduction 2

$\begin{array}{ll}2.1 & \text { Background }\end{array}$

2.2 Program Plan 3

2.3 Program Approach 4

3.0 Technical Discussion 5

3.1 Selection of Coating Compositions and Application Processes 5

3.2 Optimization of Plasma Sprayed, Chemical and/or Physical 9

Deposited and Enamel Candidates for Coating Adherence

3.2.1 Plasma Coating

3.2.2 Chemical and/or Physical Deposited Coatings 13

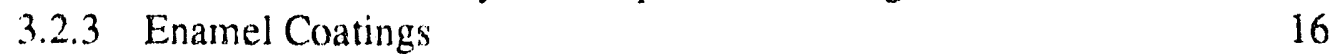

3.3 Pin-On-Disk Screening of Candidate Coatings for Wear and 16 Friction

3.3.1 Description of Pin-On-Disk Test Procedure 16

3.3.2 Wear Resistant Plasma Spray Coatings 17

3.3.3 Candidate Wear Resistant Chemical/Physical Vapor 23

Deposited Coatings

3.3.4 Wear Resistant Enamel Coatings $\quad 27$

3.3.5 Candidate Piston Ring and Cylinder Liner Coating Pairs 33

Stelected for Furiher Optimization

3.4 Optimization of Coatngs for Friction and Wear 33

3.4.1 Description of Hohman A.6 Friction and Wear Test Procedure 33

3.4.2 Friction and Wear Results 35

3.4.3 Selection of Piston Ring/Cylinder Liner Wear Resistant 51

Coating Pairs Which Meet the Program Goals

3.5 Characterization of Candidate Wear Resistant Piston Ring 51

Cylinder Coating Pairs Which Demonstrated Excellent

Friction and Wear Performance

3.5.1 Development of Wear Curves 51

3.5.2 Oxidation Resistance $\quad 52$

3.5.3 Thermal Shock Resistance $\quad 56$

3.6 Additional Glassy Phase Development 56

$\begin{array}{ll}4.0 & \text { Conclusions }\end{array} 65$

5.) Recommendations for Additional Work 67

Appendix $1 \quad$ Individual Pin-On-Disk Friction and Wear Results 68 


\section{List of Figures}

Page

Figure 2.2.1 Wear Resistant Coating Development Program Plan

Figure 3.2.2 Schematic of the Tensile Pull Test for Measuring

Adherence

Figure 3.2 3 Revetest Results:- Titanium Carbonitride Specimen 1

Figure 3.2.4 Revetest Results:- Titanium Carbonitride Specimen 2

Figure 3.3.0 Schematic of the Pin-on-Disk Friction and Wear Test 17

Figure 3.3.1 Surfaces After Pin-on-Disk Testing--Plasma Sprayed 20

Chromia-Silica Composite

Figure 3.3.2 Surfaces After Pin-On-Disk Testing-_Plasma Sprayed 21

Figure 3.3.3 SEM Photomicrographs of Layered Titanium 24

Nitride/Titanium

Carbide After Pin-On-Disk Testing

Figure 3.3.4 SEM Photomicrographs of CVD Chrome Carbide After 25

Pin-on-Disk Testing

Figure 3.3.5 SEM Photomicrographs of Mid-temperature CVD 26

Titanium Carbonitride After Pin-On-Disk Testing

Figure 3.3.6 Surfaces of Solar VPC Enamel After Pin-On-Disk

Testing

Figure 3.3.7 Surfaces of Solar VPC Enamel Containing Chrome

Oxide Particles After Pin-On-Disk Testing

Figure 3.4.1 Schematic of Hohman A-6 Double Rub Shoe Friction and Wear Tester

Figure 3.4.2 Surfaces After Hohman A-6 Testing- Test 44, Plasma Sprayed High Carbon Iron- Molybdenum Coated Shoes

Running Against a Plasma Sprayed Chromia-Silica Disk

A. Plasma Sprayed Chromia-Silica Disk 37

B. Plasma Sprayed High Carbon Iron- $\quad 38$

Molybdenum Shoes

Figure 3.4.3 Surfaces After Hohman A-6 Testing:-Test 45, Plasma

Sprayed PS 212 Shoes Running Against a Plasma Sprayed

Chromia-Silica Disk

A. Plasma Sprayed Chromia-Silica Disk

B. Plasma Sprayed PS 212 Shoes

Figure 3.4.4 Surfaces After Hohman A-6 Testing:-Test 42, Plasma

Sprayed Chromia- Silica Shoes Running Against a

Plasma Sprayed Chromia- Silica Disk

A. Plasma Sprayed Chromia-Silica Disk $\quad 42$

B. Plasma Sprayed Chromia-Silica Shoes 43 


\section{List of Figures (Cont'd)}

Figure 3.4.5 Surfaces After Hohman A-6 Testing:- Test 49, Mid-temperature Ti(C,N) CVD Coated Shoes

Running Against a Plasma Sprayed Chromia-Silica Disk
A. Plasma Sprayed Chromia-Silica Disk
B. Mid-temperature Ti(C,N) CVD Shoes

Figure 3.4.6 Surfaces After Hohman A-6 Testing:-Test 43, Plasma Sprayed High Carbon Iron-Molybdenum Coated Shoes Running Against a LTAVD Chrome Nitride Coated Disk
A. LTAVD Chrome Nitride Disk
B. Plasma Sprayed High Carbon Iron-Molybdenum Shoes 46

Figure 3.4.7 Surfaces After Hohman A-6 Testing:-Test 50,

Mid-temperature Ti(C,N) Coated Shoes Running Against a LTAVD Chrome Nitride Coated Disk

A. LTAVD Chrome Nitride Disk

B. Mid-temperature Ti(C,N) CVD Shoes

Figure 3.5.1 Wear Curve For High Carbon Iron-Molybdenum Shoes

Running Against the Chromia-Silica Dısk

Figure 3.5.2 Wear Curve For Chromia-Silica Disk Running Against High 54 Carbon Iron-Molybdenum Shoes

Figure 3.5.3 Wear Curve For High Carbon Iron-Molybdenum Shoes 54 Running Against the Chrome Nitride Disk

Figure 3.5.4 Wear Curve For Chrome Nitride Disk Running Against High 55 Carbon Iron-Molybdenum Shoes

Figure 3.5.5 Chromia-Silica Coated Falex Specimens After Thermal Shock 58 Testing

Figure 3.5.6 High Carbon Iron-Molybdenum Coated Falex Specimens After 59 Thermal Shock Testing

Figure 3.6.1 CIPE Surfaces After Pin-On-Disk Testing 62

Figure 3.6.2 Cross-Sectional Optical Photomicrograph of CIPE Plus Solid 63 Lubricant Composition Applied to Cast Iron Substrate

Figure 3.6.3 Effect of Heating Rate on CIPE Plus Solid Lubricant 64 Microstructure 


\section{List of Tables}

Page

Table 3.1.1 Four General Coating Deposition Techniques 5

Table 3.2.1 Thermal Expansion Coefficients 10

Table 3.2.2 Effect of Grading on Thermal Expansion Coefficients 10

$\begin{array}{lll}\text { Table 3.2.3 Tensile Pull Adherence Results-Plasma Sprayed Coatings } & 12\end{array}$

$\begin{array}{lll}\text { Table 3.2.4 Tensile Pull Adherence Results-Graded Coatings } & 12\end{array}$

Table 3.3.1 Summary of Pin-On-Disk Friction and Wear Tests--Piston 19

Table 3.3.2 Summary of Pin-On-Disk Friction and Wear Tests-Cylinder 22 Liner Coatings

Table 3.3.3 Pin-On-Disk Friction and Wear Results-_Plasma Sprayed 68 Coatings

Table 3.3.4 Pin-On-Disk Friction and Wear Results-Chemical, Physical 70 Deposited Coatings

Table 3.3.5 Pin-On-Disk Friction and Wear Results--.-Hard Particle 28 Additions to Vitreous Phase Coating (VPC)

Table 3.3.6 Pin-On-Disk Friction and Wear Results-Hard-Particle 32 Additions to Cast Iron Porcelain Enamel

Table 3.4.1 Hohman A-6 Friction and Wear Results-Running Against a 36 Candidate Chromia-Silica Cylinder Liner Coating

Table 3.4.2 Hohman A-6 Friction and Wear Results--Running Against a 36 Candidate LTAVD Chrome Nitride Cylinder Liner Coating

Table 3.4.3 Hohman A-6 Friction and Wear Results---Running Against a Candidate High Carbon Iron-Molybdenum Cylinder Liner 


\title{
DEVELCPMENT OF WEAR-RESISTANT CERAMIC COATINGS FOR DIESEL ENGINE COMPONENTS
}

\author{
M. H. Hase!korn, Sr. Project Engineer, Caterpillar Inc.
}

\begin{abstract}
1.0 Abstract

Improved fuel economy and a reduction of emissions can be achieved by insulation of the combustion chamber components to reduce heat rejection. However, insulating the combustion chamber components will also increase the operating temperature of the piston ring/ cylinder liner interface from approximately $150 \mathrm{C}$ to over $300 \mathrm{C}$. Existing ring/liner materials can not withstand these higher operating temperatures and for this reason, new materials need to be developed for this critical tribological interface. The overall goal of this program is the development of piston ring/ cylinder liner material pairs which would be able to provide the required friction and wear properties at these more severe operating conditions. More specifically, this program first selected, and then evaluated, potential wear resistant coatings which could be applied to either piston rings and/or cylinder liners and provide, at $350 \mathrm{C}$ under lubricated conditions, coefficients of friction below 0.1 and wear rates of less than $25 \times 10^{-6} \mathrm{~mm} /$ hour.
\end{abstract}

The processes selected for applying the candidate wear resistant coatings to piston rings and/or cylinder liners were plasma spraying, chemical vapor, physical vapor and low temperature arc vapor deposition techniques as well as enameling techniques The adherence of each coating and application process selected to either cast iron (for potential cylinder liner coatings), H-13 tool steel or 17-4 PH stainless steel (for potential piston ring coatings) was determined using a modified tensile pull adherence test. Except for two ceramic coating candidates, all the coatings had acceptable adherence. The two plasma sprayed ceramic coatings which had unacceptable adherence had significantly low. $\mathrm{r}$ thermal expansion coefficients than the metallic substrates on which they were applied. A graded coating, containing various layers containing different ratios of metallic bond coat to ceramic, was devised for these to coatings to gradually reduce these differences in thermal expansion. These graded coatings had significantly improved adherence.

Research sponsored by the U.S. Department of Energy, Assistant Secretary for Conservation and Renewable Energy, Office of Transportation Technologies, as part of the Ceramic Technology Project of the Advanced Materials Development Program, under contract DE-AC05-84OR21400 with Martin Marietta Energy Systems, Inc., Work Breakdown Structure Subelement 1.3.3.1. 
Next, each coating was screened for friction and wear at 350 C, lubricated, using a Falex Pin-on-Disk friction and wear test machine. Using the results of the pin-on-disk screening as a guide, 12 potential piston ring and cylinder liner coating pairs were selected. These coating pairs were then further optimized for friction and wear using a Hohman A-6 Double Rub Shoe friction and wear machine. Again, the testing was done at $350 \mathrm{C}$, under lubricated conditions.

Upon completion of the Hohman A-6 optimization, the following two piston ring/cylinder liner coating pairs were identified as meeting the friction and wear goals of this program:

1. A plasma sprayed high carbon iron-molybdenum piston ring coating running against a plasma sprayed chromia-silica cylinder liner coating; and,

2. A plasma sprayed high carbon iron-molybdenum piston ring coating running against a low temperature arc vapor deposited chrome nitride coating.

The thermal shock (down-cycle from $650 \mathrm{C}$ to $100 \mathrm{C}$ ) and oxidation resistance $(500$ hours at $400 \mathrm{C}$ in a simulated diesel engine exhaust atmosphere) of these coatings were determined next. In addition, a complete wear curve for each coating pair was obtained. All the coatings were able to withstand the thermal shock and oxidation testing without any coating spallation or excessive oxidation. The wear curves showed that the high carbon iron-molybdenum and chromia-silica coatings, if applied at thicknesses above 15 microns, will meet commercial diesel engine durability requirements. The chrome nitride coating also will meet the commerical diesel engine duribility requirements if it is applied at thicknesses above 15 microns. However, current LTAVD chrome nitride coating technology can only deposit 3-5 micron thick chrome 'tride coatings. Therefore, coating techniques need to be developed and optimized for applying adherent, 15 micron thick, chrome nitride coatings to cast iron substrates.

Finally, simulated piston ring and cylinder liner specimens were coated and sent to Battelle for additional friction and wear characterization in their high temperature friction and wear test rig.

\subsection{Introduction}

\subsection{Background}

The development of low heat rejection diesel engine technology involves insulating the combustion chamber components to achieve improvements in both fuel economy and emissions. Insulating the combustion chamber components increases the cylinder operat 
ing temperatures above those currently found in existing engine designs. Materials used in current diesel engine designs will not meet the commercial durability requirements if the cylinder temperatures are increased much over the current temperatures. New materials, which can meet these durability requirements, need to be developed so that the advantages of insulating the engine to reduce heat rejection can be achieved.

One of the critical tribological interfaces which needs to be improved, due to the implementation of insulated components, is the piston ring/cylinder liner interface. These interfaces in current diesel engine designs operate at approximately $150 \mathrm{C}$ and can preform in excess of 10,000 hours of engine operation using conventional diesel fuels before they need to be replaced. Insulating the combustion chamber can increase the piston ring/ cylinder liner interface temperature to $300 \mathrm{C}$ or above. Current piston ring and cylinder liner materials can not withstand these operating conditions. For this reason, wear coatings, which can be applied to piston rings and cylinder liners, need to be developed for these advanced low heat rejection diesel designs.

The c."erall objective of this program is the development of adherent, wear resistant coatings which can be applied to either piston rings and/or cylinder liners. These advanced wear coatings must have a lubricated friction coefficient of 0.1 or less, and a wear rate of less than $25 \times 10^{-6} \mathrm{~mm} /$ hour with the following test conditions: boundary lubrication, a pin load of 2.3 kilograms, and a velocity of 206 meters per second. The wear goal of $2.5 x$ 10 " $\mathrm{mm} /$ hour is consistent with the need to have the piston rings and cylinder liners which can operate for $10,0(0)$ hours or 500,000 miles before replacement.

\subsection{Program Plan}

Figure 2.2 .1 contains the overall program plan. The program began by first selecting potential coating application processes and wear resistant coatring compositions which can be applied to piston ring and/or cylinder liners. Selection criteria for each coating and application method were published mechanical and physical property data as well as any friction and wear property data available in the open literature. Also considered in this selection process, were the ease and cost of applying each coating to either an outer diameter of a piston ring or the inner diameter of a cylinder liner, and any post treatment recpuired (i.e., diamond grinding).

Aftercompletion of the coating selection process, the potential wear resistant coatings were applied to various the metallic substrates and the adherence of each coating to the substrate was determined. If required, compositional or application process changes were made to 
improve the adherence of the wear resistant coatings to the metallic substrate. Then using the application process, adherence, and physical appearance as selection criteria, potential piston ring and cylinder liner wear resistant coatings vere selected for friction and wear screening. This screening was performed on a Falex pin-on-disk friction and wear tester at $350 \mathrm{C}$, lubricated, running against both ceramic and metallic counterfaces.

Figure 2.2.1 Program Plan

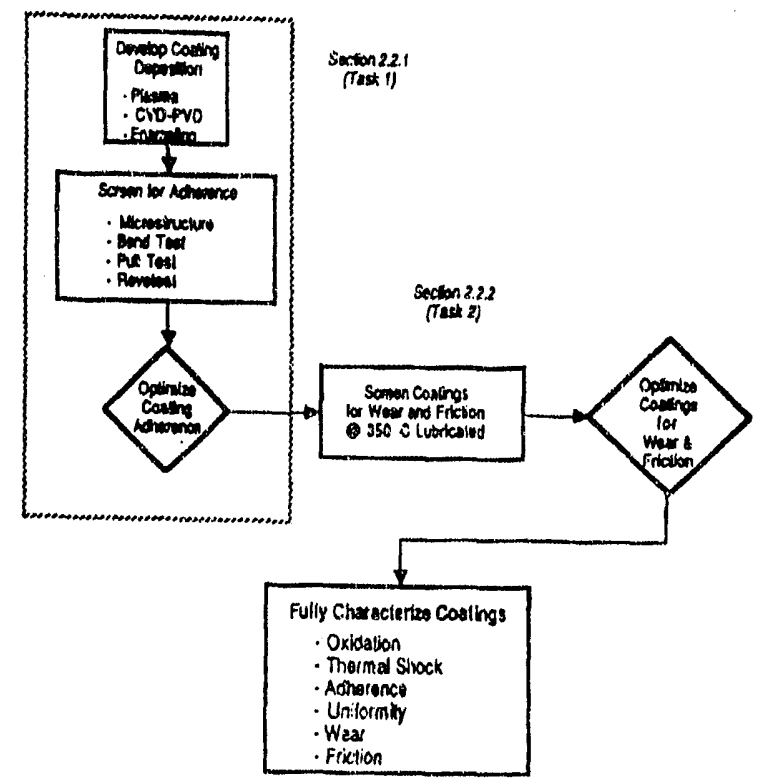

The pin-on-disk friction and wear screening identified 12 wear resistant piston ring and cylinder liner coating pairs which had the potential for meeting the friction and wear goals of this program. The friction and wear properties of these coating pairs were next optimized using an Hohman A-6 Double rub shoe friction and wear test machine. Again, the friction and wear testing was performed at $350 \mathrm{C}$ under lubricated conditions. Upon completion of this friction and wear optimization, two piston ring/cylinder liner coating pairs were identified as meeting the friction and wear goals of this program. Finally, these coating pairs were fully characterized with respect to oxidation resistance, thermal shock resistance, coating uniformity, adherence to the metallic substrate, and friction and wear.

\subsection{Program Approach}

A systems approach was selected for meeting the progran objectives. This approach was selected because of the interdependence of the variables which can affect the friction and wear properties of a coating. Two important variables which can have a significant effect on the friction and wear properties of a coating are the compatibility of the coating with the lubricant and the surface it is sliding against. 
The compatibility of the coating with the lubricant is very important. Incompatibilities of the coating with the lubricant can lead to coating corrosion, lubrication degradation, or a malfunction of the lubricating film. All these effects can significantly reduce the life of the tribological system. Compatibility of the sliding pairs is important for reducing potential problems such as catastrophic abrasive or adhesive wear and/or galling.

For these reasons, the best wear resistant piston ring and cylinder liner coating pairs were selected as early in the program as possible. In addition, only one high temperature lubricant was used throughout the program. This lubricant was used for both the initial pinon-disk friction and wear screening as well as the subsequent Hohman A-6 friction and wear optimization.

\subsection{Technical Discussion}

\subsection{Selection of Coating Compositions and Application Processes}

There are many coating deposition techniques which can apply adherent, wear resistant coatings to both the outer diameter of piston rings and the inner diameters of cylinder liners. These coating depositions techniques can be separated into four distinct groups: atomistic deposition, particulate deposition, surface modifcation and bulk coating. Table 3.1.1 lists the four general coating deposition techniques and the variou; specific coating processes included under each general coating technique. For example, chemical and physical vapor deposition is listed under atomistic deposition while plasma spraying is listed under paticulate deposition.

Table 3.1.1 Four General Coating Deposition 'lechniques
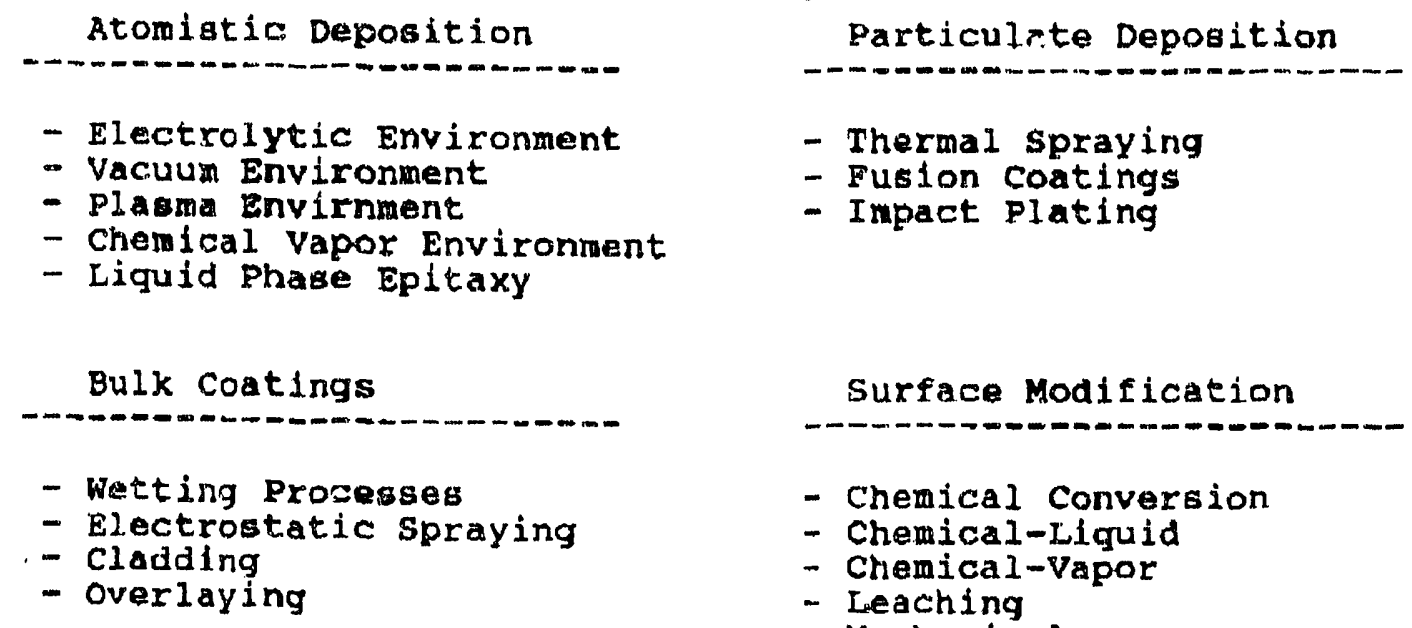

Surface Modification

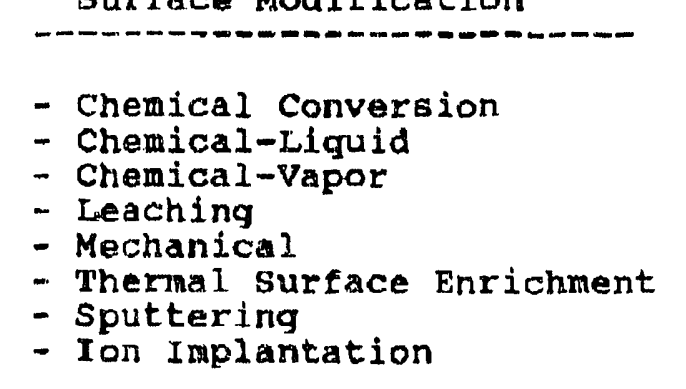


Selection of the coating deposition techniques to be evaluated was made by using preliminary base manufacturing and cost considerations. The varibles included in the preliminary base manufacturing cost were the ability of the process to easily coat the desired surface, production experience, if any, with coating deposition technique, potential for automation of the coating process, substrate surface preparation required prior to coating application, number of coating steps required to obtain the desired coating thickness, processing time, tolerance to processing variations, and the finishing requirements after coating application.

The preliminary base manufacturing and cost considerations identified five coating deposition techniques. The five coating techniques identified were: plasma spraying, chemical vapor deposition (CVD), physical vapor deposition (PVD), low temperature arc vapor deposition (LTAVD), and enameling.

Plasma spraying was selected because it is a current production process for the application of wear resistant coatings to piston rings. Caterpillar uses plasma sprayed chrome carbide piston rings in several types of production engines. An advantage of plasma spraying is that there are many powder compositions commerically available which can be applied to a wide range of metallic substrates with varying chemistries. Also, because the starting materials for plasma spraying are powders, they can be easily tailored to fit an application. For example, solid lubricants can be blended into the plasma spray powder to reduce the coefficient of friction of the applied coating, or hard particles, such as chrome carbide can be added to the powder composition to reduce the wear coefficient. Finally, powders of different chemistries can be blended together to make the thermal expansion coefficient of the plasma coating match the thermal expansion coefficient of the metallic substrate.

Plasma spray systems are available for coating both the outer diameter of piston rings (O.D. gun) and the inner diameter of cylinder liners.

After a reviewing the available literature, the following plasma spray coatings compositions were selected for evaluation as potential wear resistant coatings for either piston ring or cylinder liner applications: a chromia-silica composite; a high carbon iron-molybdenum blend; a crystalline chrome carbide, a nickel-chromium alloy; a high cobalt, molybdenumchromium alloy; NASA's self-lubricating PS 212, a high molybdenum-nickel-chromium alloy: zirconia; and a zirconia-titania-yttria composite. The plasma spray coating compositions selected included hard-facing compositions and self-lubricating compositions. 
Chemical and/or physical vapor deposited coatings are widely used on sutting tools for extended tool life. Titanium nitride and titanium carbide CVD/PVD coatings are examples of commerical coatings. In addition, preliminary work at Caterpillar has shown that applying a PVD titanium nitride coating to a piston ring can improve the wear characteristics of the ring.

An advantage of using CVD, PVD or low temperature arc vapor deposited (LTAVD) coatings is that they conform to the surface to which they are applied. This means that if they are applied to a surface with a 5 to 10 micro-inch surface finish, the CVD, PVD or LTA VD coatings will also have a 5 to 10 micro-inch surface finish. Thus, these coatings will not require any costly machining operation after application.

Three different vapor leposited coating processes were selected because each process offers certain advantages. The PVD or LTVAD coatings are applied at lower temperatures $(300-500 \mathrm{C}$ ) than a CVD coating. The $1000 \mathrm{C}$ processing temperature, required for CVD processing, usually requires that the metallic substrate be reheat treated after CVD coating to obtain the desired surface hardness required for acceptable wear resistance. With both the PVD or LTVAD, since the coating is applied at lower temperatures, a post heat treatment after coating is not required.

A mid-temperature CVD process has been developed for application of titanium carbonitride coatings to a 17-4 PH substrate. The processing temperature for this coating is $800 \mathrm{C}$ and during the cool-down the 17-4 can be heat treated to obtain the proper hardness. The $200 \mathrm{C}$ lower application temperature for this process also will reduce the amount of distortion which occurs to piston rings during coating with a conventional CVD process. Again, piston ring distortion will not be a problem with either the PVD or LTAVD processes due to their lower application temperatures.

One advantage of the CVD process is it can be used for applying thicker coatings (10-15 microns) than either the PVD or LTAVD coating processes (3-5 microns). Unlike the lower temperature coating processes, a layered composite coating can be applied using the CVD process. Finally, the higher processing temperatures for the CVD process, the CVD coatings usually have better adhesion to the metallic substrate than the PVD or LTAVD coatings.

Both the CVD and PVD are potential techniques for applying wear resistant coatings to piston rings. These techniques, however, are not suited for coating the inner diameter of cylinder liners. The LTAVD process, on the other hand, uses a directed source. Thus, this technique can be used to apply wear resistant coatings to the inner diameters of surface finished cylinder liners. 
Chemical, physical, and low temperature arc vapor deposited coating processes were selected. The chemical and physical vapor deposited coating techniques were used to apply wear resistant coatings to piston rings. The low tomperature are vapor deposition technique was evaluated as a potential technique for applying a war resistant coatings to the inner diameters of cylinder liners. The following coatings from each process were chosen for evaluation:

1. Chemical Vapor Deposited Coatings -..- chrome carbide; a layered titanium carbide, titanium nitride, and a tungsten/ tungsten carbide mixture,

2. Mid-temperature Chemical Vapor Deposited Coating -. Titanium carbonitride,

3. Physical Vapor Deposited Coating -... Titanium nitride, and

4. Low Temperature Arc Vapor Depnsited Coating -- Chrome ritride.

Enameling was the third application process selected. Enameling offers several cost advantages over plasma spraying or chemical, physical or low temperature are vapor coating techniques. The enamel coatings use inexpensive raw materials and can be applied to the inner diameters of cylinder liners using conventional robotic slurry spraying techniques. In addition, the enamel compositions can be tailored to adhere strongly to and closely match the thermal expansion coefficient of cast iron substrate. Most importantly, many enamels after applicition and firing, have very smooth, hard surfaces. These surfaces may require only a minimum amount of machining to obtain the proper surface finish.

Two enameling processes were evaluated for producing wear resistant enamel coatings. The first user we vitrious phase coating (VPC) technology developed at Solar Turbines, Inc. This technology was developed for applying oxidation resistant coatings to gas turbine components. The VPC technology uses water to suspend the enamel frit, slurry spray techniques for applyirg the frit to the metallic substrate, and a firing cycle for drying and fusing the enamel coating to the metallic substrate. Hard particles such as chrome oxide, alumina or zirconia can be added to the vitrious phase composition to improve the wear resistance of the enamel. In summary, the VPC approach uses an enamel composition as the adhesive for bonding hard particles to a metallic substrate.

The second enameling approach was developed by the University of Illinois. An enameling technique called the "hot substrate mettod," produced a wear resistant enamel coating by sprinkling and/or plasma spraying hard particles on top of a molten enamel layer. The wear resistant enamel coating produced by this method, consists of hard particles embedded within the enamel.

The emamel compositions selected for both techniques had thermal expansion confficients which closely matched that of the cast iron substrate. The reason for the matching of the thermal expansion cuefficients was to reduce the amount of residual stresses which develop 
within the enamel and/or metallic substrate either during the cool-down after the initial firing cycle or during the combustion cycle heat-up to $350 \mathrm{C}$. The residual stresses which develop due to thermal expansion differences could cause the enamel coating to disbond or spall from the metallic surface.

\subsection{Optimization of Plasma Sprayed, Chémical and/or Physical Deposited, and Enamel Candidates for Coating Adherence}

\subsubsection{Plasma Coatings}

\subsubsection{Thermal Expansion Determinations}

The thermal expansion coefficien of a plasma coating applied to a metallic subsit ate should closely match the thermal expansion coefficient of the substrate I arge differences in thermal expansion coefficients can result in the development of resi...al stresses, either in the coating or substrate. These residual stresses can lead to coating failure.

The thermal expansion coefficient of each candidate plasma spray coating was determined from room temperature to $1000 \mathrm{C}$. All the thermal expansion determinations were made using a Theta Industries, Inc., High Temperature Double Pushrod Dilatometer. The specimens were hollow cylinders of each of the plasma sprayed powders. These specimens were obtained by plasma spraying each coating composition on a meral rod, cutting the specimens to length, and finally, removing the metal rod by acid etching.

The thermal expansion coefficients were detennined for both the graded and nongraded plasma sprayed coatings as well as the cast iron, $\mathrm{H}-13 \mathrm{tool}$ steel, and 17-4 PH stainless steel substrates. The results are listed in Table 3.2.1. The grey cast iron and H-13 tool steel had thermal expansion coefficients at $4(x) \mathrm{C}$ of $12.2 \times 10^{-6} \mathrm{C}$ and $14.4 \times 10^{-6} \mathrm{C}$, respectively. The thermal expansion oefficients of these metallic substrates are very similar to the thermal expansion coefficients of the following plasma spray coatings: NiCrAlY bond coat; nickelchromium alloy; high cobalt, molybdenum, chromium alloy; high carbon iron-molybdenum blend; NASA self-lubricating PS 212; and high molybdenum, nickel, chromium alloy. As a result, these plasma spray coatings can be applied to either the cast iron or $\mathrm{H}-1.3 \mathrm{lool}$ steel and can be heated to $400 \mathrm{C}$ without creating large residual stresses in either the plasma coating or metallic substrate. The zirconia, and titania, yttric composite plasma coatings, on the other hand, had thermal expansion coefficients significantly lower than those of the metallic substrate. These coatings, if applied to either the cast iron or $\mathrm{H}-13$ substrate, could spall or disbond from the metallic substrate either after application or when the component is heated to $400 \mathrm{C}$ if a method for minimizing the thermal expansion mismatch stresses is not used. 
Table 3.2.1 Thermal Expansion Coefficients $\left(10^{-6} \mathrm{C}\right)$

\begin{tabular}{|c|c|c|}
\hline SUBSTRATES & $200 c$ & $400 \mathrm{C}$ \\
\hline $\begin{array}{l}\text { K-13 Tool steel } \\
\text { Gray cast Iron }\end{array}$ & $\begin{array}{l}11.5 \\
12.3\end{array}$ & $\begin{array}{l}12.2 \\
14.4\end{array}$ \\
\hline PIASKA SPRAY COATINGS & & \\
\hline $\begin{array}{l}\text { Nickel-chroms Alloy } \\
\text { High Cobalt-Molybdenum Alloy } \\
\text { Chrome Carblde with Solid Lubricants } \\
\text { High Molybdenum, Nlokel, Chrome Alloy } \\
\text { High Carbon Iron-Molybdenum Alloy } \\
\text { 2irconia, Titania, Yttria powder } \\
\text { zlrconla } \\
\text { Molybdenua }\end{array}$ & $\begin{array}{r}10.7 \\
9.9 \\
9.6 \\
10.6 \\
8.8 \\
7.6 \\
8.0 \\
1.2\end{array}$ & $\begin{array}{r}11.7 \\
11.3 \\
11.3 \\
11.3 \\
11.1 \\
8.4 \\
8.0 \\
4.8\end{array}$ \\
\hline Bond coat & 12.3 & 13.7 \\
\hline
\end{tabular}

The effect of grading plasma coatings on thermal expansion was determined by Caterpillar in contract DEN3-332 of the DOE/NASA Heavy Duty Transport Technology program. In this program, it was learned that the thermal expansion coefficients of plasma spray coatings can be tailored to match the thermal expansion coefficient of a metallic substrate by blending plasma coatings with significantly different thermal expansion coefficients. The thermal expansion coefficient of this coating will follow the rule of mixtures. That is, a $50 / 50$ blend, by volume, will have a thermal expansion coefficient midway between that of the individual plasma spray coatings.

Table 3.2.2 illustrates the effect of blending the zirconia plasma spray coating with the bond coat on the thermal expansion coefficient. Using different zirconia and bond coat ratios, a graded plasma coating system was developed for both these ceramic coatings. The graded coating systems had graded thermal expansion coefficients-matching the metallic substrate on one end, and the zirconia top coating on the other end.

Table 3.2.2 Effect of Grading on Thermal Expansion Coefficients $\left(10^{-6} \mathrm{C}\right)$ $\begin{array}{ll}\text { substates } & 400 \mathrm{C}\end{array}$

$\begin{array}{lr}\text { H-13 Tool steel } & 12.2 \\ \text { Gray Cast Iron } & 14.4 \\ \text { Graded Plama Coating Compositions } & 8.1 \\ 1008 \text { Zirconia } & 9.5 \\ 758 \text { ziconia/ } 25 \% \text { Bond Coat } & 10.9 \\ 508 \text { zirconia/ } 508 \text { Bond Coat } & 11.0 \\ 258 \text { Zirconia/ } 75 \% \text { Bond coat } & 13.7 \\ 100 \% \text { Bond Coat } & \\ \text { (All percentages are volume percent) }\end{array}$




\subsubsection{Plasma Spray Coating Adherence Determinations}

Using thermal expansion determinations as a guide, the adherence of the following plasma spray coatings was determined, after application to either cast iron and/or $\mathrm{H}-13$ tool steel substrates, without grading: nickel-chromium alloy; high cobalt, molybdenum, chromium alloy; chromia-silica composite; high carbon iron-molybenum blend; high molybdenum, nickel, chromium alloy; and NASA self-lubricating PS212. The thermal expansion determinations also showed that graded coating schedules had to developed for the zirconia and zirconia-titania-yttria coatings. The adherence of these graded coatings was also determined.

The adherence determinations were made using the tensile pull adherence test illustrated in Figure 3.2.1. In general, the test setup consisted of two plasma sprayed specimens bonded to two uncoated substrates. The epoxy selected for bonding the components together had a shear strength of 27.6 MPa. After curing the epoxy, the two uncoated substrates were pulled in tension. Pulling the uncoated specimens in tension caused a shear stress to develop within both the plasma sprayed coating and the epoxy. In this test, if the shear strength of the plasma coating or plasma coating/metallic interface was greater than the shear strength of the epoxy, the specimen failed at a load of $27.6 \mathrm{MPa}$. When the shear strength of either the plasma spray coating or the coating/ metallic interface was less than the shear strength of the epoxy, the specimen failed at loads below 27.6 MPA, and the failure occurred within the coating or at the coating/ metallic interface.

The adherence of all the candidate plasma coatings was determined. These results are listed in Table 3.2.3. The following plasma coatings had adherence values $>27.6 \mathrm{MPa}$ when applied to either the cast iron or $\mathrm{H}-13$ tool steel substrates: high cobalt, molybdenum, chromium alloy; high carbon iron-molybdenum blend; high molybdenum, nickel, chromium alloy; high molybdenum composite; and the NASA PS212. The nickel-chromium alloy recorded a $17.4 \mathrm{MPa}$ adherence when applied to the cast iron substrate. This coating spalled after application when plasma sprayed onto the $\mathrm{H}-13$ tool steel. Finally, the chromia-silica composite recorded 13.2 and $9.7 \mathrm{MPa}$, adherence values for the cast iron and $\mathrm{H}-13$ tool steel, respectively. It should be noted that, since these coatings did not spall during the initial pin-on-disk friction and wear screening, adherence values above 9.7 MPa can be considered acceptable tensile pull adherence values.

The adherence determinations for the graded coatings are listed in Table 3.2.4. These results show that for the coatings applied to the cast iron, grading reduced the adhesion of the coating to the substrate. However, because all the adherence values were above 9.7 MPa, this reduction in adhesion should not be large enough to cause coating spallation in a sliding wear application. The adhesion of the graded zirconia coatings was poorer on the 
H-13 tool steel than the cast iron. Also, grading had little effect on the adhesion. Finally, grading the zirconia, titania, yttria composite improved the adhesion of this coating when it was applied to an $\mathrm{H}-13$ tool steel substrate.

Table 3.2.3. Tensile Pull Adherence Results--Plasma Sprayed Coatings

\begin{tabular}{lcc} 
COATING & GRAY CAST IRON \\
\hline Nickel, Chrome Alloy & $17.4 \mathrm{MPa}$ & Spalled \\
$\begin{array}{l}\text { High Cobalt, Molybdenum, } \\
\text { Chrome Alloy }\end{array}$ & $>27.6 \mathrm{MPa}$ & $>27.6 \mathrm{MPa}$ \\
Chromia-sillca Composite & $13.2 \mathrm{MPa}$ & $9.7 \mathrm{MPa}$ \\
$\begin{array}{l}\text { High Carbon Iron-Molybdenum } \\
\text { Componite }\end{array}$ & $>27.6 \mathrm{MPa}$ & $>27.9 \mathrm{MPa}$ \\
High Molybdenun, Nickel, Chrome & $>27.6 \mathrm{MPa}$ & $>27.6 \mathrm{MPa}$ \\
Alioy & $>27.6 \mathrm{MPa}$ & $>27.6 \mathrm{MPa}$ \\
High Molybdenum Composite & $>27.6 \mathrm{MPa}$ & $>27.6 \mathrm{MPa}$ \\
PS 212 & &
\end{tabular}

Table 3.2.4. Tensile Pull Adherence Test Results--Graded Coatings

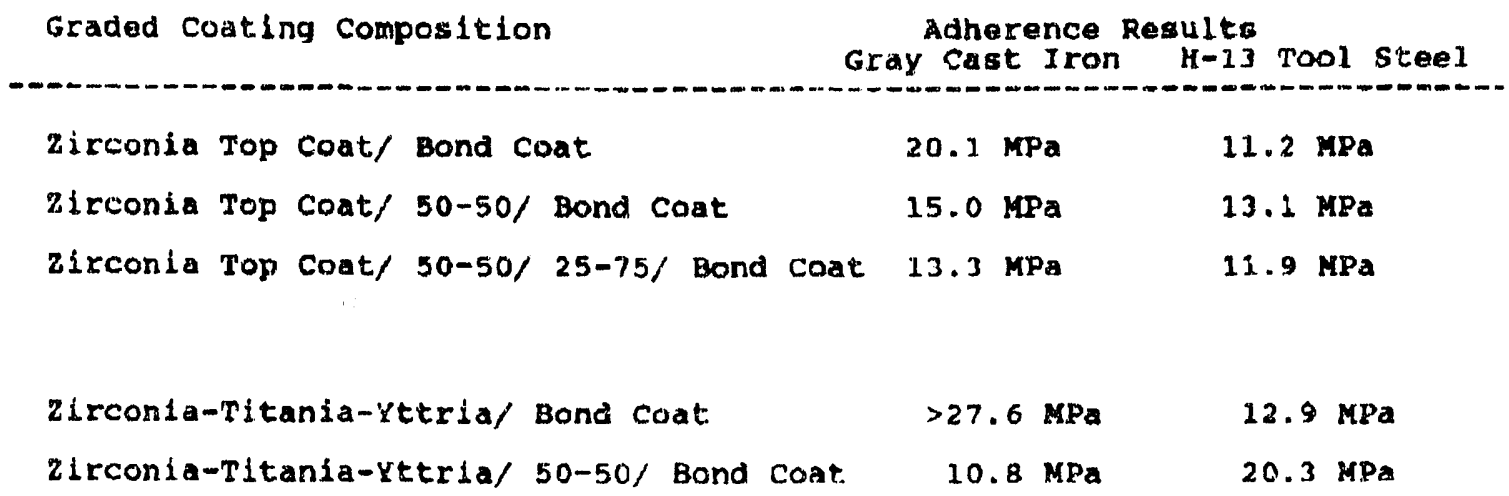


FIGLRE 3.2.1

SCHEMATIC OF THE TENSILE PULL TEST FOR MEASURING ADHERENCE

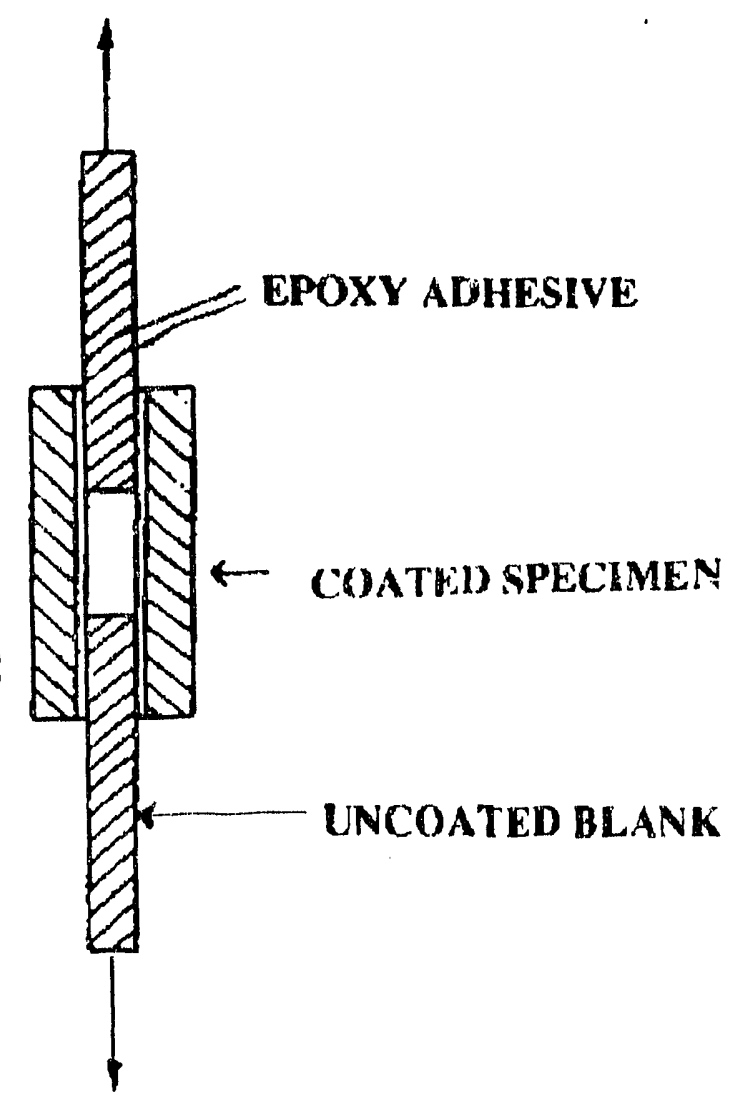

\subsubsection{Chemical and/or Physical Deposited Coatings}

\subsubsection{Physical Appearance}

The high temperature chemical vapor deposited (CVD) chrome carbide and layered titanium carbide/titanium nitride coatings were applied to $\mathrm{H}-13$ tool steel substrates. The mid-temperature CVD titanium carbonitride applied to a 17-4 stainless steel substrate. These CVD coatings had an excellent physical appearance anci no coating flaking or spalling was noted on any of the specimens. An optical microscopy analysis performed on these specimens indicated that the coatings were uniformly applied, and no adverse chemical reactions between the coatings and substrate occurred during the coating process. Using cross-sectional optical photomicrographs the thicknesses of the CVD coatings were determined to be:

Chrome carbide--5 microns,

Titanium carbonitride- 14 microns, Layer titanium carbide/tianium nitride-- 8 microns. 
A physical vapor deposited (PVD) titanium nitride coating was also applied to the $H-13$ tool steel substrate. A metallographic analysis of this coating showed that the PVD titanium nitride coating was not uniform, varying in thickness from less than 1 micron to over 3 microns across the three inch width of the specimen.

The CVD tungsten/tungsten carbide coating applied to the $H-13$ tool steel substrate had an excellent physical appearance. However, the tungsten/ tungsten carbide coating cannot bond directly to the $\mathrm{H}-13$ tool steel substrate. For this reason, a nickel oxide layer was first applied and the tungsten/tungsten carbide coating was deposited on top of the nickel oxide layer. Problems were encountered obtaining a smooth, uniform nickel oxide layer on the $\mathrm{H}-13$ tool steel substrate. As a result, the surface roughness of the tungsten/tungsten carbide coated specimens ranged from 10 to 50 micro-inches.

\subsubsection{Adherence Determinations}

At first, a Revetest was used for determining the mechanical strength; i.e., adhesion and intrinsic cohesion, of the chemical and physical vapor deposited coatings. In general, the Revetest scratches the surface of the coated substrate with a smoothly rounded diamond point while simultaneously applying a load to the tip. The load is increased until a piezoelectric accelerometer detects an acoustic emission as the coating is disturbed. Depending on the nature of the coating disturbance; i.e., cracking, flaking, smearing, the pattern and intensity of the acoustic emission varies.

Figures 3.2.2 and 3.2.3 contain the Revetest results obtained from two mid-temperature chemical vapor deposited titanium carbonitride coated specimens applied to $\mathrm{H}-13$ tool steel substrates. These specimens were processed together in the same reactor. The Revetest results for these specimens show that for one specimen the maximum acoustic emission occurred at a 1000 gram load while for the second specimen the maximum acoustic emission occurred at a load of 200 grams. Also, the shape of the load versus maximum acoustic emission for each specimen was very different. Optical photomicrographs of with each Revetest trace illustrate that the physical appearance of the scratches were identical on both specimens. Thus, the results obtained from the Revetest on two specimens with identical coatings were very different. Finally, the comparison of the Revetest results obtained from different chemical vapor deposited coating compositions also provided inconclusive results. For this reason, it was decided to use the tensile pull adherence test for determining the adherence of all chemical and physical vapor deposited specimens. 
FIGURE 3.2.2

REVITEST RESULTS SPECIMEN 1

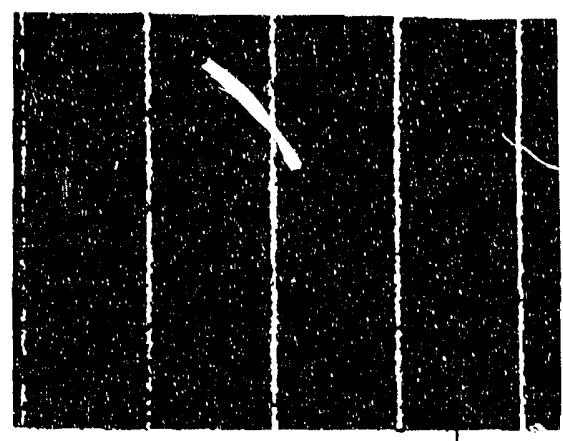

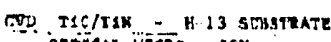

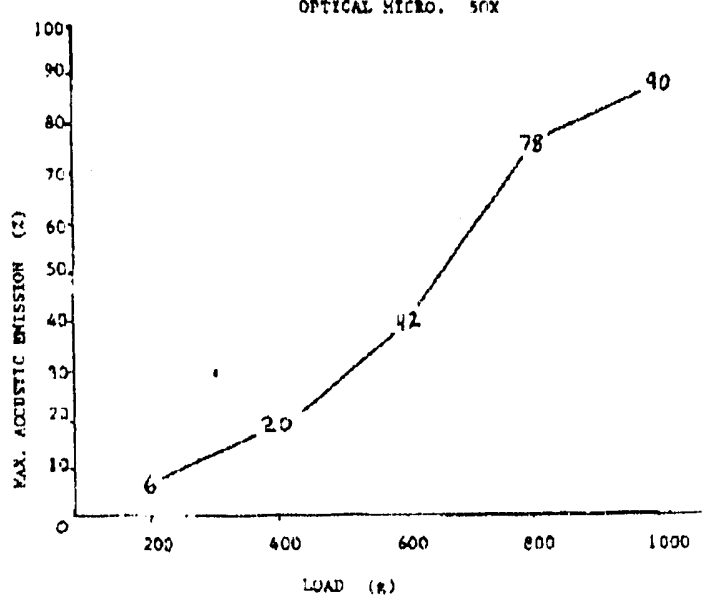

FIGURE 3.2.3

REVITEST RESULTS

SPECIMEN 2
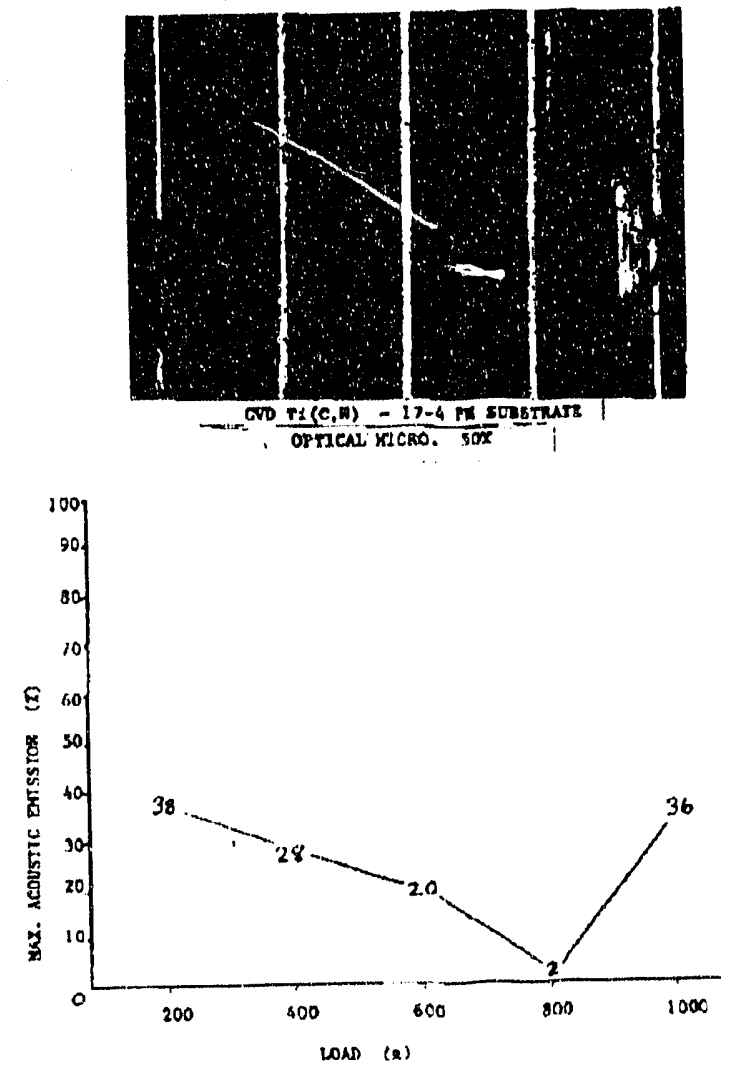

All chemical and physical vapor deposited specimens failed at loads greater than $27.6 \mathrm{MPa}$. Examination of the specimens after testing showed that the failure occurred within the epoxy. Thus, all chemical and physical deposited coatings were determined to have acceptable adherence.

The physical vapor deposited titanium nitride coating was not included in the adherence determinations because the optical microscopy analysis of this coating showed it was nonuniformly applied to the H-13 tool steel substrate. 


\subsubsection{Enamel Coatings}

The criteria for selecting an enamel composition involved an enamel composition which had a thermal expansion coefficient matched closely to the thermal expansion of the metallic substrate. In addition, the chemistry and firing cycle for the enamel must not cause an excessive amount of oxidation of the metallic substrate. Excess oxidation of the metallic substrate during firing can adversely affect the adherence of the enamel to the substrate. Finally, enamel compositions with low elastic modulii and favorable Poisson's ratios were selected. These properties are important when enamels are loaded with the hard particles.

The Solar VPC enamel composition required development of a bond coating to the metallic substrate prior to the VPC enamel. The bond coat had a similar chemistry as the VPC enamel but also contained $\mathrm{NiO}, \mathrm{Co}_{3} \mathrm{O}_{4}$, and $\mathrm{MnO}_{4}$. Without first applying the bond coat the adherence of the VPC enamel to the cast iron substrate was only marginal.

After selection of the enamel composition, it was loaded with 50 volume percent silicon carbide hard particles. During the firing of the enamel the silicon carbide reacted with the molten enamel producing very porous coatings. Thus, to prevent this undesirable chemical reaction from occurring, the hard particle additions should be oxides, such as chrome oxide, or stable carbides (i.e., chrome carbide).

The University of Illincis successfully plasma sprayed zirconia, chrome oxide, and chrome carbide over an A.I. Andrew's cobalt based enamel composition. These specimens had to be machined after plasma spraying to achieve the desired surface finish.

Sprinkling silicon carbide or silicon nitride onto a molten enamel resulted in very porous, rough coatings which were poorly bonded to the metallic substrate.

\subsection{Pin-on-Disk Screening of Candidate Coatings for Wear and Friction (350 C,Lubricated)}

\subsubsection{Description of Pin-On-Disk. Test Procedure}

Screening of candidate coatings for friction and wear characteristics was performed on a Falex No.6 Multi-specimen Test Machine. Figure 3.3.1 illustrates the pin-on-disk test configuration. Tests were performed at $350 \mathrm{C}$ with a normal load of $22.25 \mathrm{~N}$ and a surface velocity of $3.4 / \mathrm{sec}$. The test temperature was attained by a combination of resistive heating coils embedded in the walls of the oil reservoir surrounding the test specimens and heating elements placed in cavities drilled into the lower table on which the disk specimen was mounted. 
The contact surface of the test specimens was completely submerged in the test lubricant, an experimental synthetic lubricant supplied by Lubrizol. Oil was delivered to the reservoir by a peristaltic pump at a rate of $3.6 \mathrm{ml} / \mathrm{min}$., allowing the oil to have approximately a three minute residence time in the reservoir. The candidate wear resistant coatings were applied to either cast iron or $\mathrm{H}-13$ tool steel disks. Partially stabilized zirconia, AISI $440 \mathrm{C}$ stainless steel, alumina, or silicon nitride pins were used as the opposing counterfaces. Each test was run for 30 minutes before the test was stopped to measure the wear scar on the diameter of the pin as well as the coated disk. A Form Talysurf measured the extent of wear which occurred during each test. If the wear rate after the initial 30 minutes of testing was accentable, the specimens were reassembled for further testing and the procedure repeated until a total of 2 hours of test time was accumulated.

FIGURE 3.3.1 SCHEMATIC OF THE PIN-ON-DISK

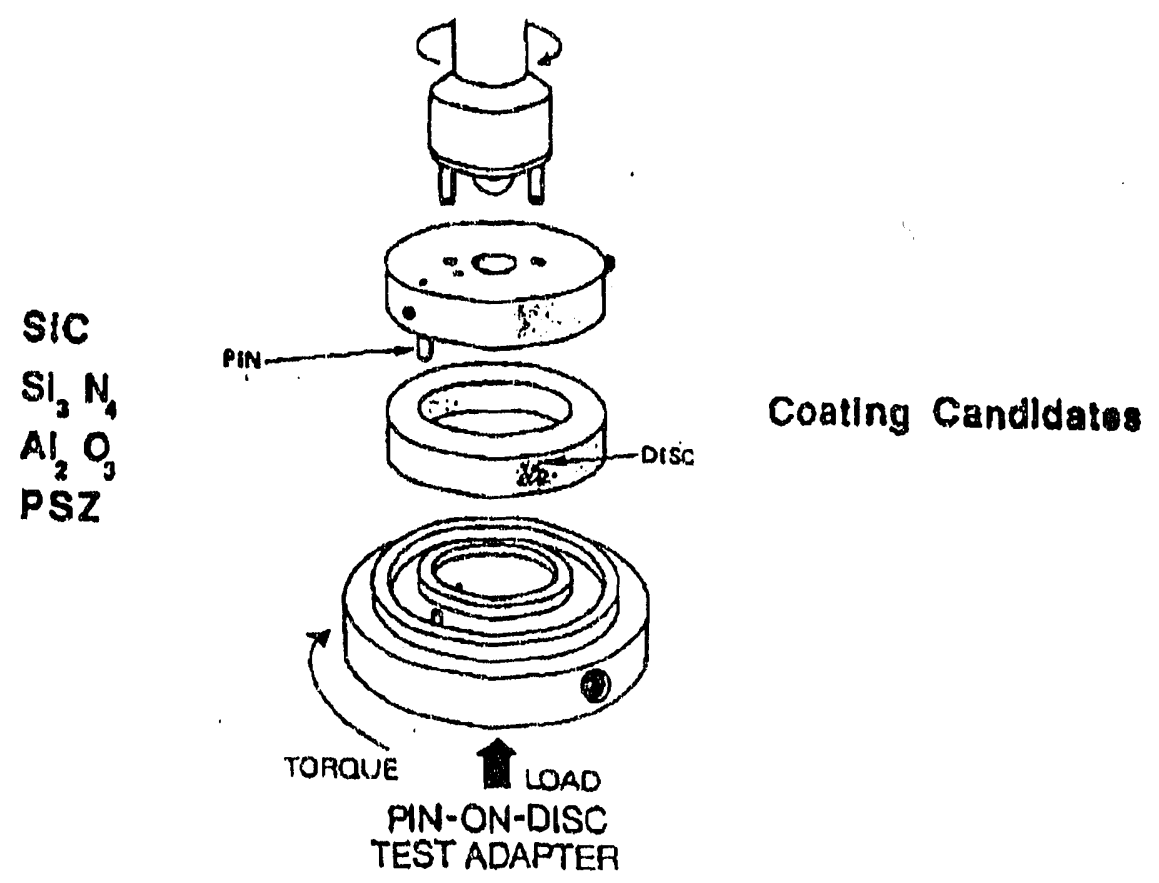

FRICTION \& WEAR TEST

\subsubsection{Wear Resistant Plasma Spray Coatings}

The thermal expansion and adherence determinations identified the following six plasma spray coatings as potential wear resistant piston ring coatings: chromia-silica composite; high carbon iron-molybdenum alloy; NASA self-lubricating PS 212; high cobalt-chromium alloy with TRIBALOY intermetallic additions; high molybdenum, nickel, chro-. mium blend; and nickel, chromium, molybdenum blend. In addition, the thermal expansion and adherence determinations identified the following four coatings as potential wear 
resistant cylinder liner coatings: chromia-silica composite; high carbon iron-molybdenum alloy; zirconia, titania, yttria blend; and the zirconia graded with $\mathrm{NiCrAl}$ bond coat. Tables 3.3.1 and 3.3.2 contain summaries of the pin-on-disk friction and wear screening results for these plasma sprayed coatings. The individual test data is contained in Tables 3.3.3 to 3.3.6.

Running either a ceramic or metallic counterface against the chromia-silica composite produced low coefficient of friction values $(0.09-0.13)$ and average wear coefficients of $10^{-7} \mathrm{~mm}^{3} / \mathrm{N}-\mathrm{m}$ for the coating and $10^{-8} \mathrm{~mm}^{3} / \mathrm{N}-\mathrm{m}$ for either counterface. Optical photomicrographs of the wear track for this coating are contained in Figure 3.3.1. These photomicrographs show that the wear mechanism, which occurred during the test, was the ceramic counterface polishing the surface of the chromia-silica.

The high carbon iron-molybdenum alloy also recorded coefficients of friction between $0.09-0.13$ running against both the ceramic and metallic counterfaces. This plasma coating exhibited average wear coefficients of $10^{-8}$ and $10^{-9} \mathrm{~mm}^{3} / \mathrm{N}-\mathrm{m}$, respectively, running against the ceramic and metallic counterfaces.

Coefficient of friction values (0.04-0.13) were obtained running the PS 212 coating against either the ceramic or metallic counterfaces. However, the average wear coefficients of 10 6 to $10^{-7} \mathrm{~mm}^{3} / \mathrm{N}$ - m obtained running PS2 12 against the ceramic and metallic counterfaces were borderline.

Both the high carbon-chromium alloy with TRIBALOY intermetallic materials and the high molybdenum, nickel, chromium coatings exhibited high coefficient of friction values (O.18-0.33) running against either counterface. Average wear coefficients obtained from these coatings ranged between $10^{-8}$ and $10^{-7} \mathrm{~mm}^{3} / \mathrm{N}-\mathrm{m}$ running against the ceramic counterface. Average wear coefficient of $10^{-6} \mathrm{~mm}^{3} / \mathrm{N}-\mathrm{m}$ was obtained running a metallic counterface against the high molybdenum, nickel, chromium coating. For this reason, a $2.5 \mathrm{~mm}$ wear scar developed in the coating after only 60 minutes of testing. The photomicrographs in Figure 3.2.2 show that the wear mechanism for the high molybdenum, nickel, chromium coating was abrasive wear. The reason for the poor wear properties was the cracking and subsequent spalling of this coating under the load of the ceramic counterface.

The nickel, chromium, molybdenum plasma coating recorded low coefficient of friction values $(0.07-0.13)$ as well as low average coating and counterface wear coefficients $\left(10^{-8}\right.$ $\left.\mathrm{mm}^{3} / \mathrm{N}-\mathrm{m}\right)$ running against the ceramic counterface. Higher coefficient of friction values $\left(0.15-(0.26)\right.$ and average wear coefficients $\left(10^{-7} \mathrm{to} 10^{-6} \mathrm{~mm} \mathrm{~m}^{3} / \mathrm{N}-\mathrm{m}\right)$ were observed running this coating against a metallic counterface. 
Table 3.3.1

Summary of Pin-On-Disk Friction and Wear Testing Candidate Piston Ring Coatings Running Against the Zirconia Counterface

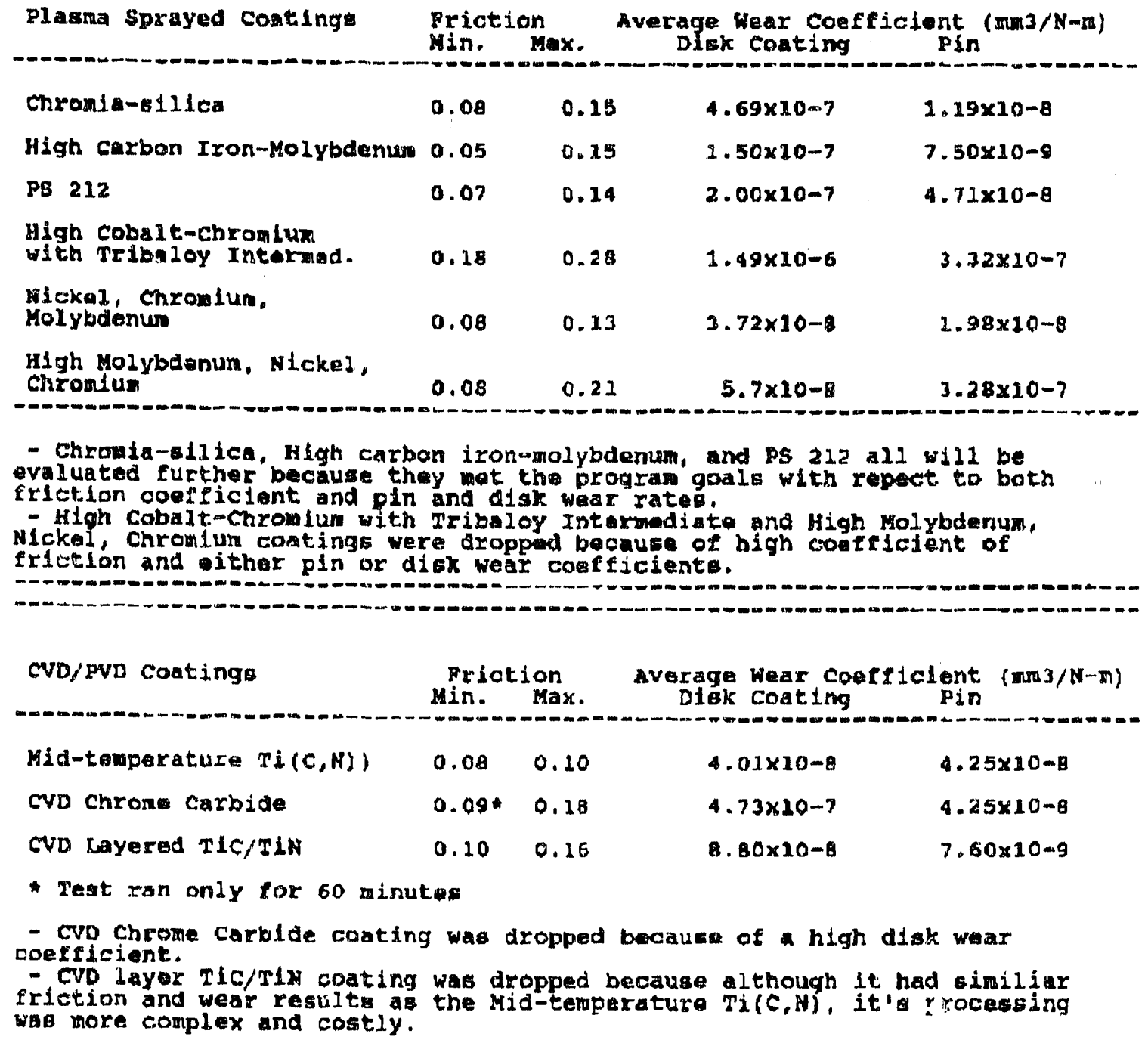


FIGURE 3.3.1

SURFACES AFTER PIN-ON-DISK TESTING

PLASMA SPRAYED CHROMIA-SILICA COMPOSITE

\section{MAGNIFICATION 50X}

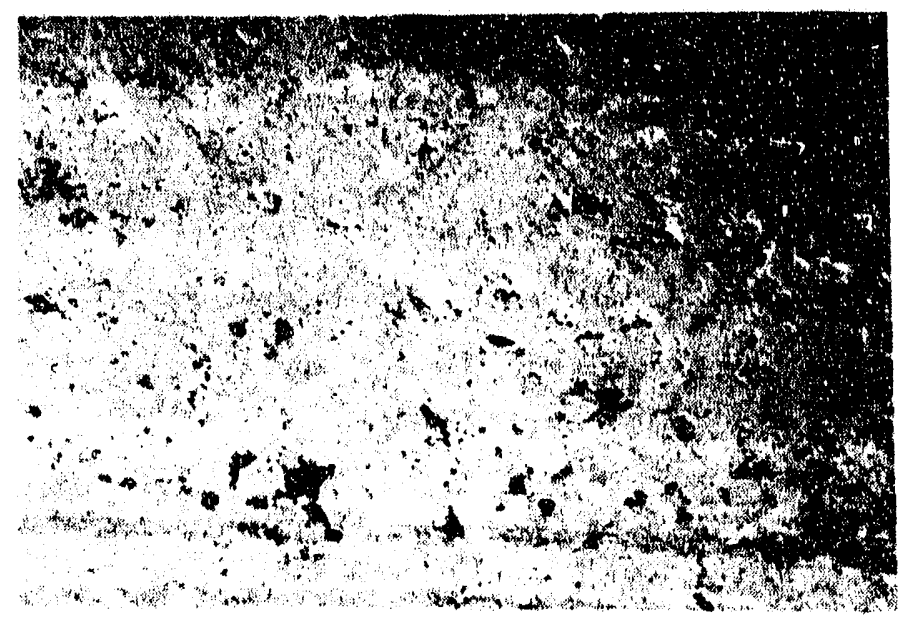

\section{MAGNIFICATION 200X}

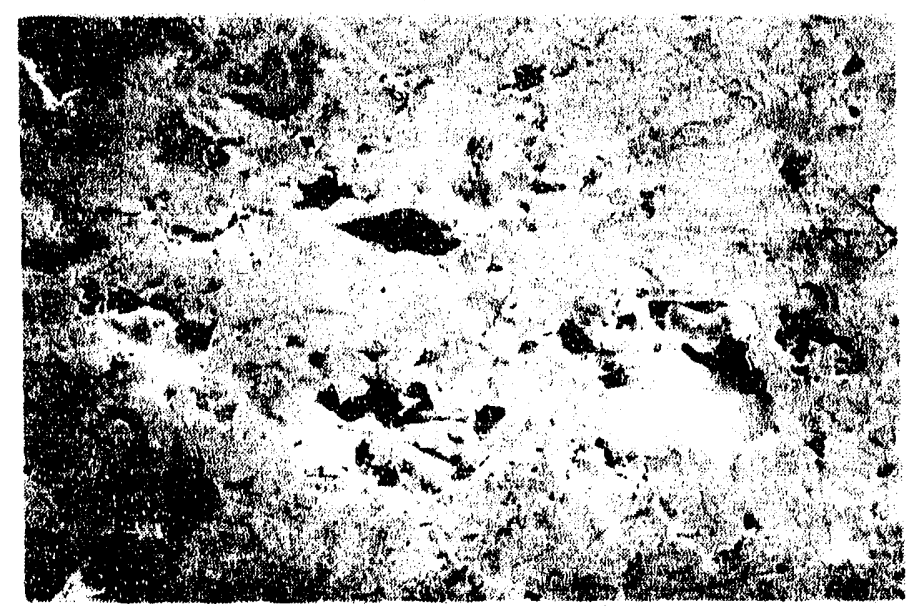


Table 3.3.2

Summary of Pin-On-Disk Friction and Wear Testing Candidate Cylinder Liner Coatings Running Against the Zirconia Counterface

\begin{tabular}{|c|c|c|c|c|}
\hline Plasma Sprayed Coatings & \multicolumn{2}{|c|}{$\begin{array}{l}\text { Mriction } \\
\text { Min. Max. }\end{array}$} & \multicolumn{2}{|c|}{$\begin{array}{l}\text { Average Wear coefficient (mm } / \mathrm{N}-\mathrm{m} \text { ) } \\
\text { Dlsk Coating Pin }\end{array}$} \\
\hline Chronia-silica & 0.08 & 0.15 & $4.69 \times 10-7$ & $1.19 \times 10-8$ \\
\hline High Carbon Iron-Molybdenum & 0.05 & 0.15 & $1.50 \times 10-7$ & $7.50 \times 10-9$ \\
\hline LTAVD Chrome Nitrlde & 0.09 & 0.29 & $3.10 \times 10-8$ & $2.86 \times 20-8$ \\
\hline Graded 2 irconla & 0.14 & 0.19 & $1.86 \times 10-6$ & $1.23 \times 10-7$ \\
\hline $\begin{array}{l}\text { Zirconia, Titania, yttria } \\
\text { Composite }\end{array}$ & 0.09 & 0.19 & $3.10 \times 10-8$ & $2.04 \times 10-8$ \\
\hline
\end{tabular}

- Both the Graded zirconia and zirconia, Titania, Yttría composite were dropped because of high coefficlent of friction and wear coefficients

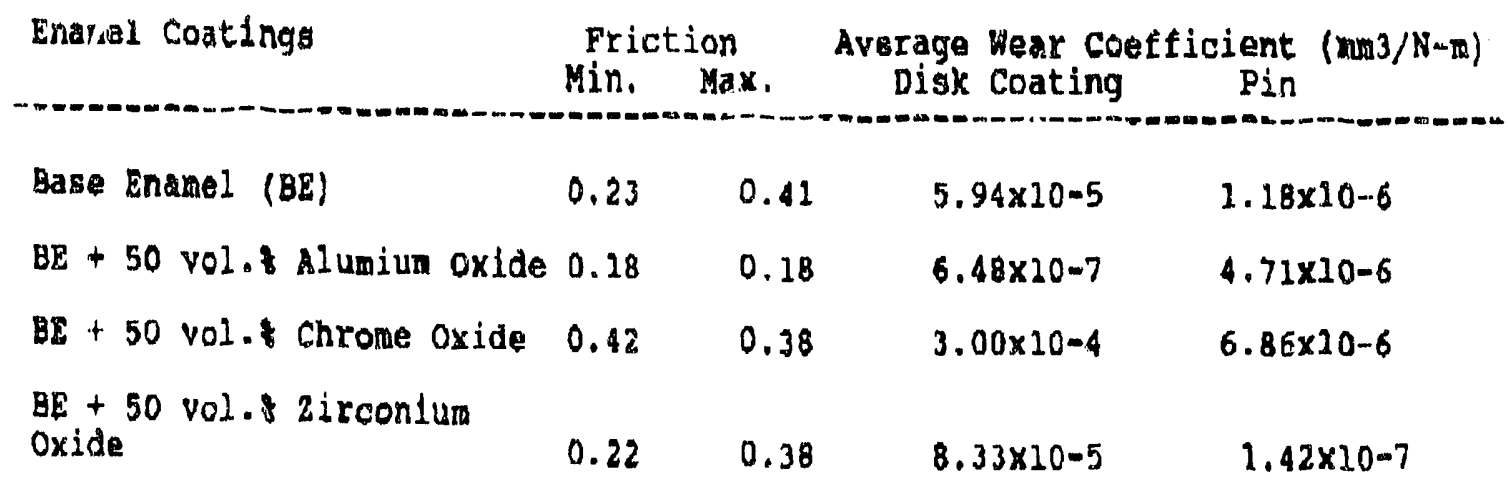

The graded zirconia and the zirconia, titania, yttria blend recorded coefficients of friction values hetween $0.15-0.38$ and average wear coefficients of $10^{-6}$ and $10^{-7} \mathrm{~mm}^{3} / \mathrm{N}-\mathrm{m}$ running against the ceramic counterface.

In summary, the friction and wear screening of the plasma sprayed coatings identified the chromia-silica composite, high carbon iron-molybdenum alloy and the self-lubricating PS2 12 as candidates for further friction and wear optimization. These coatings exhibited coefficients of friction and average wear coefficients which met the goals of this program. The cobalt-chromitum alloy with TRIBALOY intermetallic additions, the high molybde- 
num-nichel-chromium blend, and the nickel-chromium-molybdenum blend exhibited either coefficient of friction values above 0.2 or average wear coefficients above $10^{-6} \mathrm{~mm} /$ $\mathrm{N} \cdot \mathrm{m}$ running against either the ceramic or metallic counterface. For these reasons, these coatings were not chosen for further optimization.

\subsubsection{Candidate Wear Resistant Chemical/Physical Vapor Deposited Coatings}

Two chemiival vapor deposited coatings, chrome carbide and a layered titanium carbide/ titanium nitride, were applied to $\mathrm{H}-13$ tool steel substrates and evaluated. A midtemperature chemical vapor deposited titanium carbonitride coating was also evaluated. This coating, however, was applied to a $17-4$ stainless steel substrate. Finally, a low temperature arc vapor deposited (LTAVD) chrome nitride coating was applied to a cast iron substrate and evaluated. Tables 3.3.1, 3.3.2, and 3.3.12-15 contain the results of the pin-on-disk friction and wear screening for these coatings.

The layered titanium carbide/ titanium nitride coating recorded low coefficient of friction values $(0.08-0.18)$, and average disk and counterface wear coefficients $\left(10^{-8}\right.$ and $10^{-9} \mathrm{~mm}^{3} /$ $\mathrm{N}-\mathrm{m}$ ) runring against the ceranic counterfaces. Slightly higher coefficient of friction values $(0.18-0.22)$ were obtainied running this layered coating against the metallic counterface. These higher coefficient of friction values resulted in higher average wear coefficients $\left(10^{6} \mathrm{~mm}^{3} / \mathrm{N}-\mathrm{m}\right)$.

High coefficient of fitiction values $(0.09 .0 .59)$ and average wear coefficients $\left(10^{-7} \mathrm{~mm}^{3} / \mathrm{N}\right.$ in) were obtained running the chemical vapor deposited chrome carbide coating against the ceramic counterfaces. Running this coating against a metallic counterface also produced. very high coefficients of friction (0.24-0.31) as well as unacceptable average disk and counterface wear coefficients $\left(10^{.5}\right.$ and $\left.10^{6} \mathrm{~mm}^{3} / \mathrm{N} \cdot \mathrm{m}\right)$.

Figures 3.3.3 and 3.3.4 show that the only wear appearent on either CVD coating, after testing, was a small amount of polishing of the coating surfaces.

Very low average wear coefficients $\left(10^{-8}\right.$ to $\left.10^{-9} \mathrm{~mm}^{3} / \mathrm{N}-\mathrm{m}\right)$ were obtained running the midtemperature chemic al vapor deposited titanium carbonitride coating against either ceramic counterface. The coefficient of friction values for these specimens ranged from 0.09 to 0.15. Figure 3.3.5 reveals that polishing by the ceramic counterface was the only wear observed after the test. High coefficient of friction values $(0.24)$ and very high disk and counterface average wear coefficients $\left(10^{-6} \mathrm{~mm}^{3} / \mathrm{M}-n\right)$ were obtained running the titanium carbonitride coating against a metallic counterface. 
FIGURE 3.3.3

SEM PHOTOMICRCGRAPHS OF LAYEREN TITANIUM NITRIDE/TITANIUM CARBIDE AFIER PIN-ON-DISK TESTING

\section{MAGNIFICATION 50X}

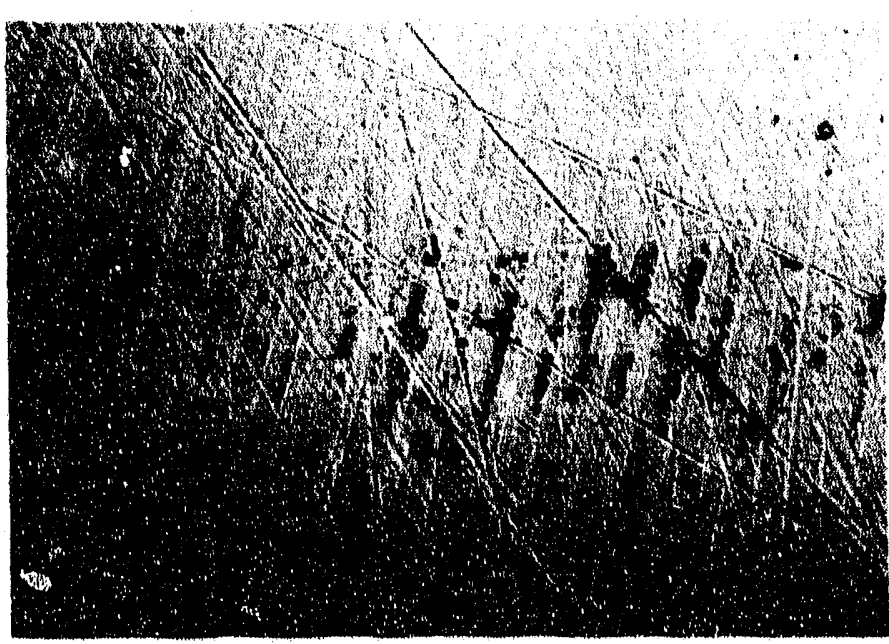

MAGNIFICATION 1000X

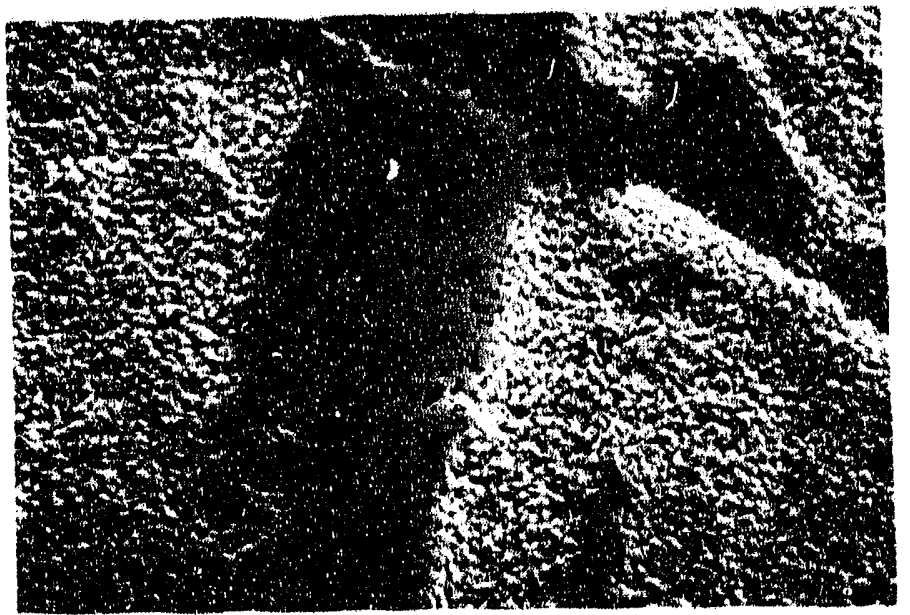


FIGURE 3.3.4

SEM PHOTOMICROGRAPHS OF

CVD CHROME CARBIDE AFTER PIN-ON-DISK TESTING

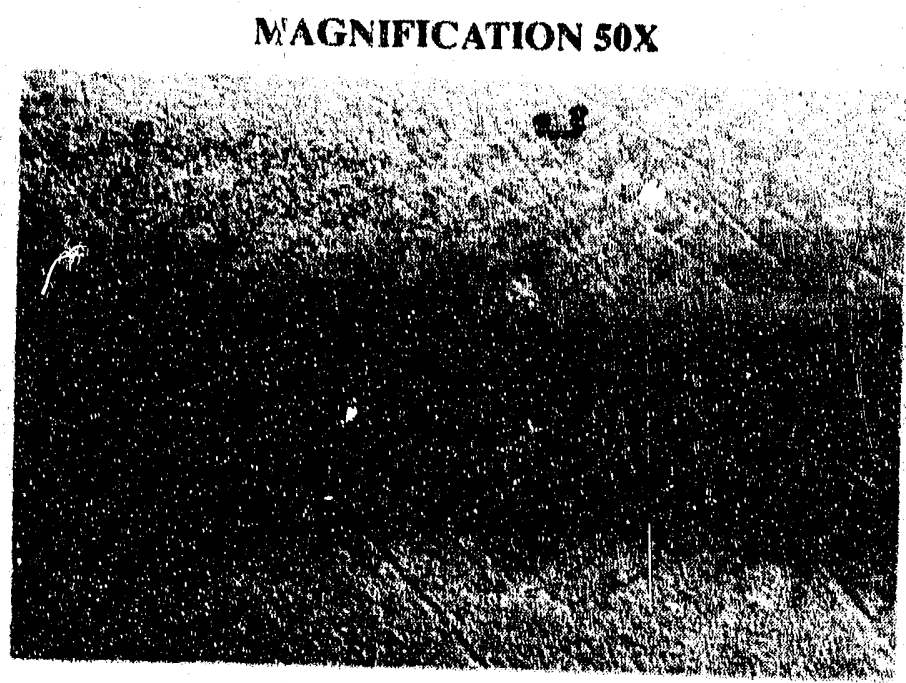

1000X MAGNIFICATION OF REGION 21

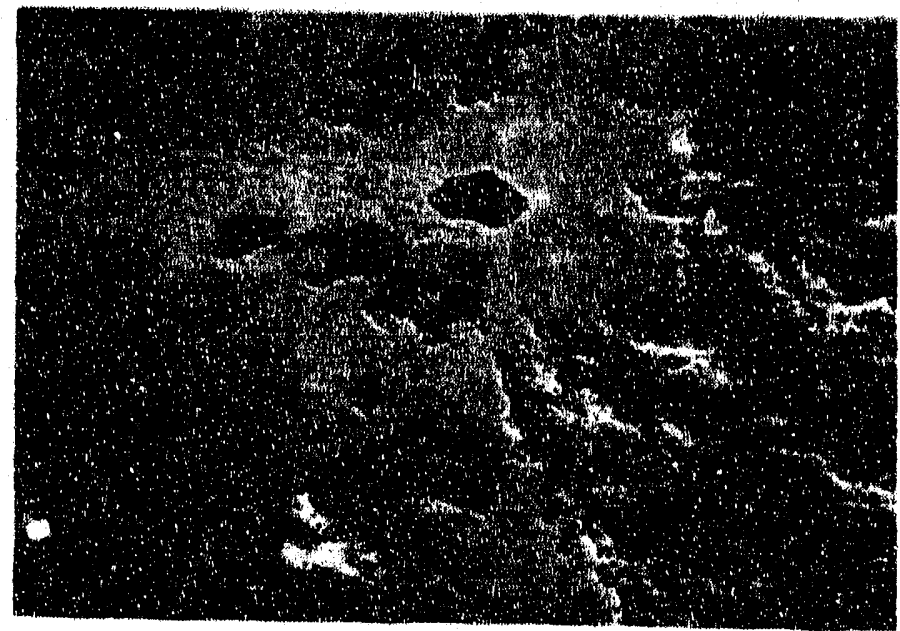


FIGURE 3.3.5

SEM PHO'TOMICROGRAPHS OF

MID-TEMPERATURE CVD TITANIUM CARBO-NITRIDE

AFTER PIN.ON-DISK TESTING

\section{MAGNIFICATION 50X}

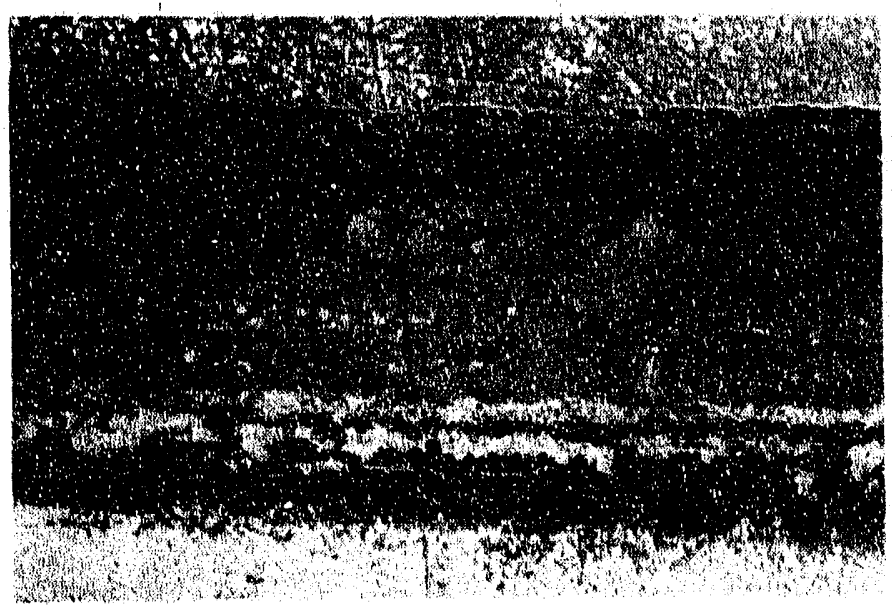

1000X MAGNIFICATION OF REGION 30

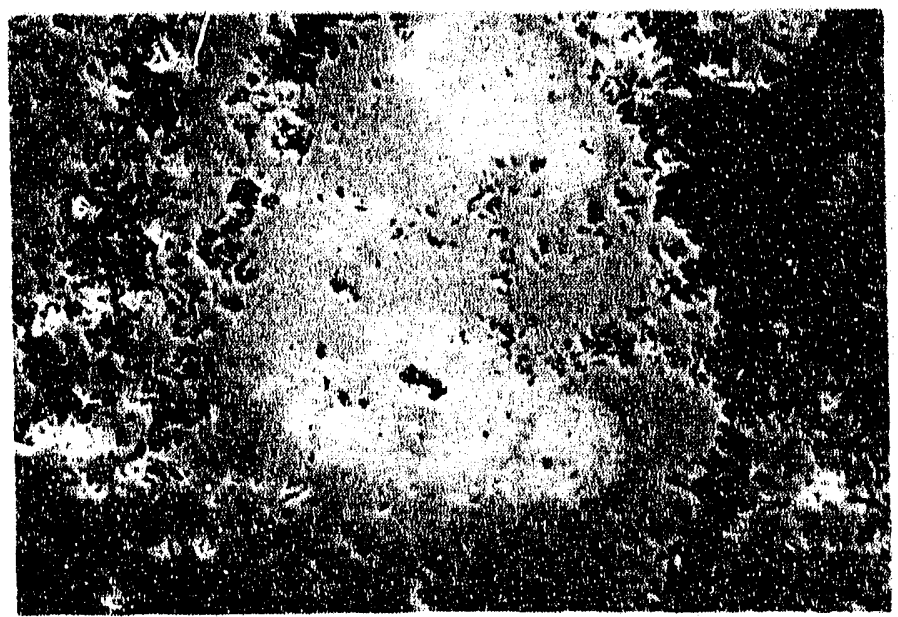


Excellent coefficient of friction values (0.08-0.19) and average wear coefficients $\left(10^{-8}\right.$ $\mathrm{mm}^{3} / \mathrm{N}-\mathrm{m}$ ) were obtained running the low temperature arc vapor deposited chrome nitride against the ceramic counterface. Coefficient of friction values ranging from $0.01-0.11$ and average wear coefficients of $10^{-7} \mathrm{~mm}^{3} / \mathrm{N}-\mathrm{m}$ were recorded running the chrome nitride against the metallic counterface.

The chemical vapor deposited tungsten/tungsten carbide specimens had a 10 to 50 microinch surface roughness. This rough surface finish caused high coefficients of friction values $(0.15-0.21)$ when this coating was run against either counterface. These high coefficient of friction values, in turn, caused wear coefficients, ranging from $10^{-6}$ to $10-^{7}$ $\mathrm{mm}^{3} / \mathrm{N}-\mathrm{n}$. However, most of the wear occurred at the start of testing; as the tungsten/ tungsten carbide surface "wore" and became smoother, the coefficient of friction decreased to below 0.2 .

The mid-temperature chemical vapor deposited titanium carbonitride, the low temperature arc vapor deposited chrome nitride and the layered titanium carbide/ titanium nitride meet the coefficient of friction and average wear coefficient goals of this program. For this reason, these coatings all are candidates for future friction and wear optimization. The chemical vapor deposited chrome carbide and tungsten/tungsten carbide coatings were not selected for further friction and wear opt:mization since these coatings recorded coefficient of friction values greater than 0.2 and wear coefficients above $10^{-7} \mathrm{~mm}^{3} / \mathrm{N}-\mathrm{m}$.

\subsubsection{Wear Resistant Enamel Coatings}

Two wear resistant enamel coating compositions and approaches were evaluated. One approach, taken by Solar Turbine, was the addition of hard particles to their proprietary Vitreous Phase Coating composition (VPC). The second approach, used by the University of Illinois, involved plasma spraying the hard particles on top of an A.I. Andrew's cobalt based enamel composition.

Solar was able to load their VPC with up to 80 volume percent oxide based hard particle additions without significantly decreasing the adherence of the VPC to the metallic substrate.

The effect of 50 and 70 volume percent hard particle additions on the friction and wear properties of the VPC were determined first. Solar prepared the following VPC compositions: the VPC without any hard particle additions (base composition), the VPC with a 50 volume percent aluminum oxide hard particle addition, the VPC with 50 and 70 volume percent chrome oxide hard particle additions, and the VPC with a 50 volume percent zirconium oxide hard particle addition. The results of this initial screening are contained in Table 3.3 .5 . 
The base Solar VPC composition without any hard particle additions exhibited high friction values $(0.11-0.44)$ and wear coefficients $\left(10^{-5} \mathrm{~mm}^{3} / \mathrm{N}-\mathrm{m}\right)$ running against either the ceramic or metallic counterface. For this reason, these tests ran only for 30 and 60 minutes respectively. Representative photomicrographs of these wear surfaces, after testing, are contained in Figure 3.3.6. These photomicrographs show that, the VPC pulverized and spalled under the compressive load applied by the ceramic counterface. The region labeled $\mathrm{N}$ in Figure 3.3.7 shows a wear track location on the disk, where coating spallation had occurred during the test. Also observed within this wear track was a thick, black residue (region labeled D).

The 50 or 70 volume percent chrome oxide, 50 volume percent aluminum oxide or 50 volume percent zirconium oxide hard particle additions to the base VPC composition did not improve the wear properties of the coating. Coefficient of friction values for these specimens ranged from 0.13 , running against the metallic counterface to above 0.5 , running against the ceramic counterface. The average wear coefficients, running against the ceramic counterface were in the $10^{-5} \mathrm{~mm}^{3} / \mathrm{N}-\mathrm{m}$ range. Slightly improved wear coefficients, $10^{-7} \mathrm{~mm}^{3} / \mathrm{N}-\mathrm{m}$, were obtained running these coatings against the metallic counterface.

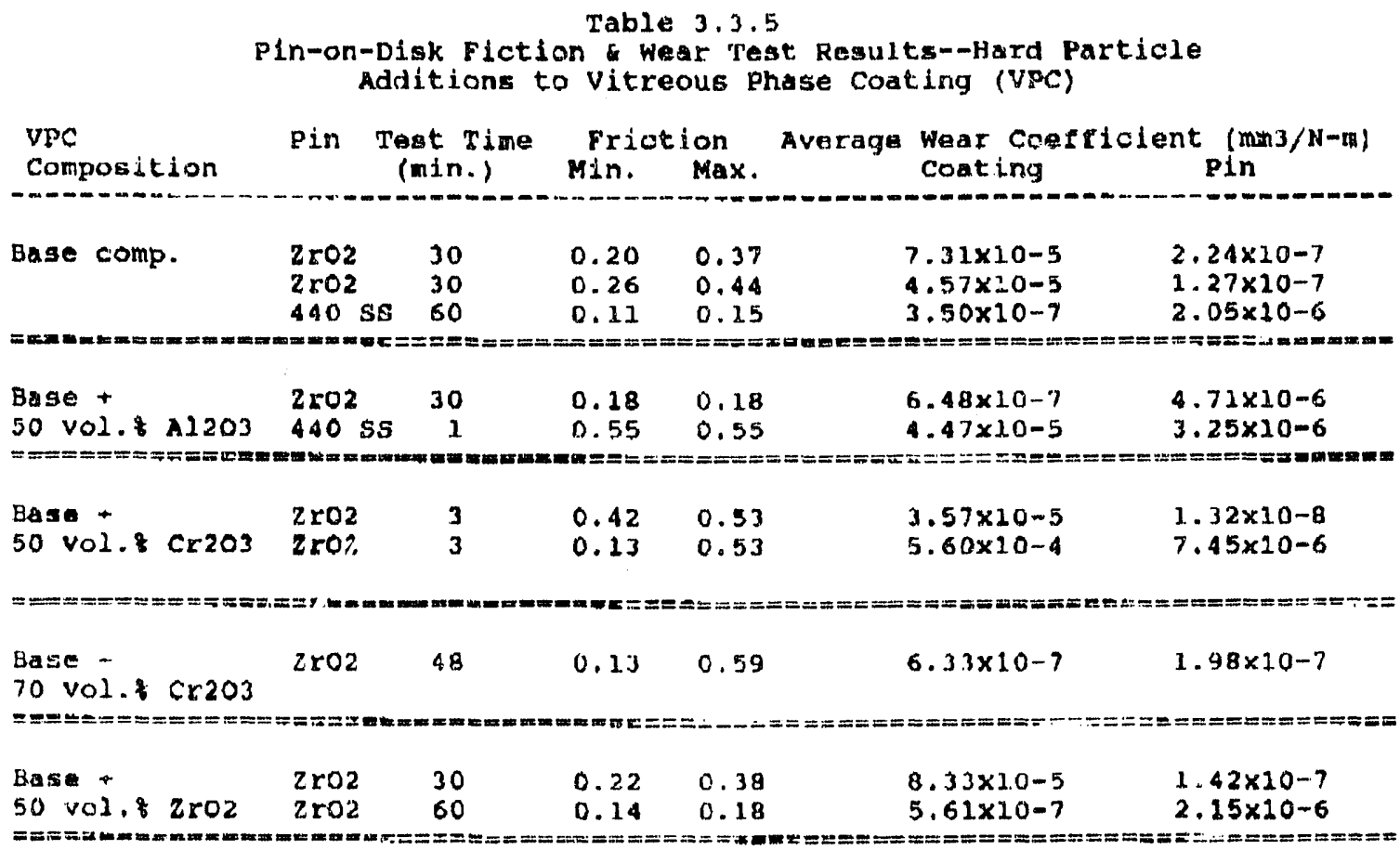

Figure 3.3.7. displays the wear tracks of the VPC plus 50 and the VPC plus 70 volume percent hard particle additions after testing. These photomicroraphs show that portions of the VPC plus hard particle coatings were completely worn to the metallic substrate during the testing. The addition of the hard particles did not improve the average wear coefficient of the VPC coating. 
FIGURE 3.3.6

SURFACE OF SOLAR VPC ENAMEL AFTER TESTING

A. MAGNIFICATION 1.5X

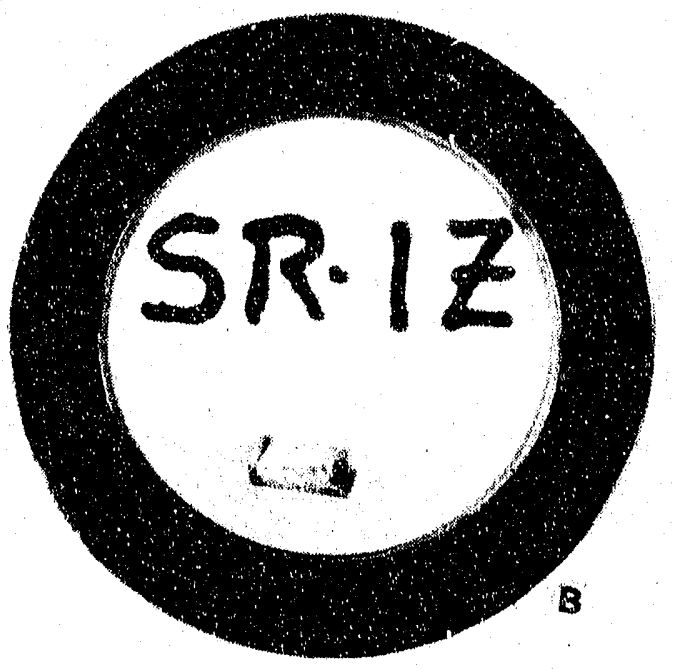

B. 10X MAGNIFICATION OF REGION B

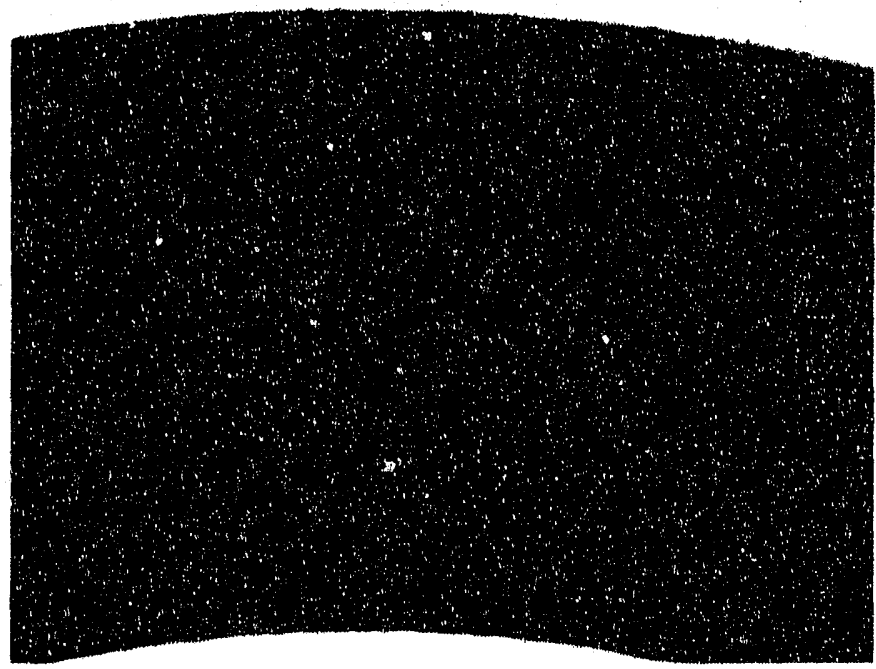


A black residue also was observed within the wear track of these specimens. This undesirable chemical reaction was the reason it was decided to discontinue the development work with the VPC enamel and switch to the A.I. Andrew's cobalt based enamel composition.

The process used by the University of Illinois to produce wear resistant enamel coatings was to plasma spray hard particles on top of an A.I. Andrew's cobalt based enamel. In general, the processing for these specimens consisted of slurry spraying an enamel coating on the specimen, firing to fuse the enamel, and then plasma spraying hard particles on top of the enamel to improve the wear properties of the enamel. The University of Illinois was able to successively plasma spray chrome carbide, chrome oxide and zirconia hard particles on top of the enamel. These coatings had their friction and wear properties evaluated running against both ceramic and metallic counterfaces a pin-on-disk test. Table 3.3.18 contain the results of this testing.

Very high friction coefficients $(0.25)$ were encountered running the plasma sprayed zirconia against the zirconia counterface. Large portions of the plasma sprayed zirconia coating spalled after only five minutes of testing and the test was terminated.

The chrome carbide plasma sprayed specimens recorded coefficient of friction values between 0.09-0.24 running against all three ceramic counterfaces. Although these coatings had relatively low coefficient of friction values, the average wear coefficients were all greater than $10^{-7} \mathrm{~mm}^{3} / \mathrm{N}-\mathrm{m}$. For this reason, these specimens ran only 48,60 and 120 minutes against either ceramic counterface before a $2.5 \mathrm{~mm}$ wear scar developed. Running against the metallic counterface, the plasma sprayed chrome carbide recorded higher coefficient of friction values $(0.24$ and 0.31$)$ and average wear coefficients $\left(10^{-6} \mathrm{~mm}^{3} / \mathrm{N}\right.$ $\mathrm{m})$. This specimen ran only 30 minutes before a $2.5 \mathrm{~mm}$ wear scar developed.

Running the zirconia counterface against the chrome oxide plasma sprayed over the enamel resulted in coefficient of friction values between 0.09-0.18, and average wear coefficients of between $10^{-6}$ to $10^{-7} \mathrm{~mm}^{3} / \mathrm{N}$-m. One specimen ran only 30 minutes, while the remaining two specimens ran for 120 minutes before developing a $2.5 \mathrm{~mm}$ wear scar.

This pin-on-disk testing showed that plasma spraying hard particles on top of an enamel bond coating would not produce coating with acceptable coefficient of friction and/or wear coefficients.

The University of Illinois produced another specimen by sprinkling silicon carbide particles on top a molten A.I. Andrews' enamel. This specimen had an extremely rough surface texture and, for this reason, had coefficient of friction values of 0.30 and average wear coefficients for both the coating and counterface of $10^{-4} \mathrm{~mm}^{3} / \mathrm{N}-\mathrm{m}$. 
FIGURE 3.3.7

SURFACE OF SOLAR VPC ENAMEL TESTING

CONTAINING CHROME OXIDE PARTICLES AFTER TESTING

(MAGNIFICATION 10X)

A. 50 VOLUME PERCENT CHROME OXIDE ADDITION

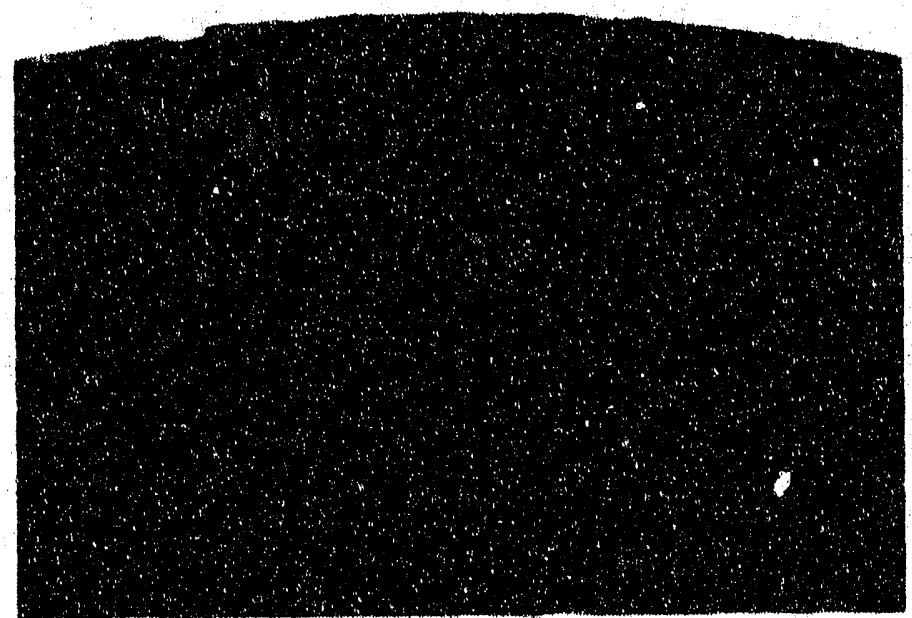

B. 70 VOLUME PERCENT CHROME OXIDE ADDITION

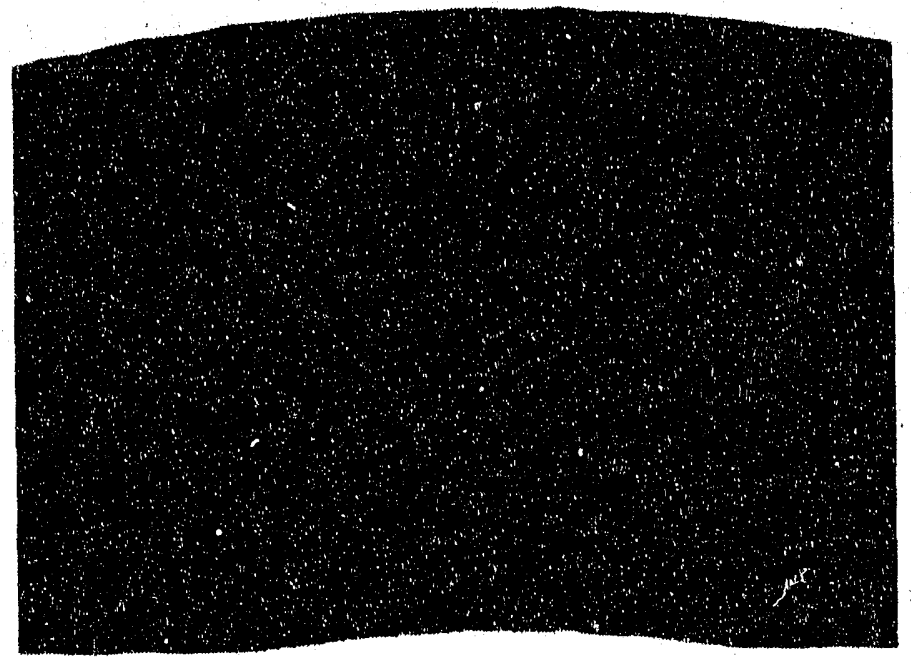


It was decided to evaluate lower volume loadings of the hard particle additions to the enamel. Hopefully, with the lower volume loading of hard particles there would be an increased amount of enamel coating around each particle improving the bonding of the particles into the enamel.

Enamel compositions containing 10 and 20 weight percent zirconium oxide, and 10 and 20 percent chrome oxide hard particle additions were processed by the University of Illinois. The friction and wear properties of the se specimens were then evaluated by running against a zirconia counterface in a lubricated pin-on-disk test. Irrespective of the hard particle composition or volume loading, the zirconia counterface wore a $2.5 \mathrm{~mm}$ wear scar in the enamel coating after only five minutes of testing.

\begin{tabular}{|c|c|c|c|c|c|c|}
\hline \multirow{2}{*}{$\begin{array}{l}\text { Coating } \\
\text { Plasma Sprayad } \\
\text { Chrome Carbide }\end{array}$} & \multirow{2}{*}{$\begin{array}{l}\text { P1n } \\
2202 \\
2 r 02 \\
2 r 02 \\
44055 \\
44055\end{array}$} & $\begin{array}{l}\text { Test Time } \\
(\min \text {.) }\end{array}$ & \multicolumn{2}{|c|}{$\begin{array}{l}\text { Friction } \\
\text { Min. Max. }\end{array}$} & \multicolumn{2}{|c|}{$\begin{array}{l}\text { Average Wear coofficient }(\mathrm{mm} / \mathrm{N}-\mathrm{m}) \\
\text { Coating }\end{array}$} \\
\hline & & $\begin{array}{r}120 \\
120 \\
120 \\
5 \quad 30 \\
\text { is } 120 \\
\end{array}$ & $\begin{array}{l}0.09 \\
0.09 \\
0.07 \\
0.15 \\
0.09 \\
0.0=2=\end{array}$ & $\begin{array}{l}0.18 \\
0.15 \\
0.20 \\
0.15 \\
0.31 \\
0===-\pi=\end{array}$ & 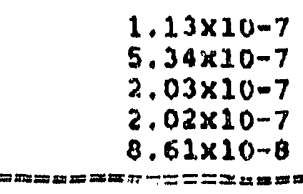 & $\begin{array}{l}2.25 \times 10-6 \\
2.44 \times 10-7 \\
2.39 \times 10-7 \\
7.38 \times 10-6 \\
1.39 \times 10-7 \\
=\end{array}$ \\
\hline $\begin{array}{l}\text { Plasma sprayed } \\
\text { Chrome Oxide } \\
\text { somm-me- }\end{array}$ & $\begin{array}{l}2502 \\
2 x 02 \\
m=m a m=\end{array}$ & $\begin{array}{r}30 \\
120 \\
===-=m=0\end{array}$ & $\begin{array}{l}0.09 \\
0.07 \\
== \pm=-=\end{array}$ & $\begin{array}{l}0.14 \\
0.16 \\
==== \pm==\end{array}$ & 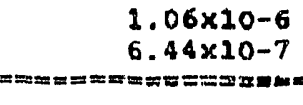 & 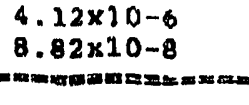 \\
\hline $\begin{array}{l}\text { Plassma Sprayed } \\
\text { zxo2 } \text { i }\end{array}$ & 2502 & 1 & 0.25 & $-\cdots$ & $---m$ & $-\infty-\infty$ \\
\hline 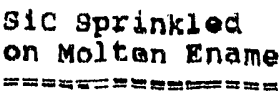 & $1^{2 \mathrm{rO2}}$ & 30 & 0.11 & 0.37 & $2.01 \times 10-4$ & $2.53 \times 10-5$ \\
\hline
\end{tabular}

"* coating developed a $2.5 \mathrm{~mm}$ wear scar in less than 2 minutes of tastinq

Finally, the University of Illinois attempted to plasma spray an A.I. Andrews' enamel composition containing a 10 volume percent zirconium oxide hard particle addition. This plasma coating contained approximately 50 volume percent porosity and had a very rough surface finish. The combination of 50 high porosity and very rough surface finish caused this specimen to develop a $2.5 \mathrm{~mm}$ wear scar after only one minute of testing when run against a zirconia counterface. 


\subsubsection{Candidate Piston Ring and Cylinder Liner Coating Pairs Selected for Further Optimization}

Three plasma spray coatings, one mid-temperature chemical vapor deposited and one LTAVD coating were selected for further optimization. Two of the plasma spray coatings, the chromia-silica and the high carbon iron-molybdenum, were chosen because both recorded low friction and wear coefficients during the initial pin-on-disk screening running against either the zirconia or 440C stainless steel counterfaces. Also selected for further optimization, was the plasma sprayed PS212. The PS212 was selected even though its wear performance was only marginal; NASA had previously published some promising results using the PS 212 coating on cylinder liners of a Sterling engine running unlubricated at elevated temperatures.

The mid-temperature titanium carbonitride chemical vapor deposited coating was selected as a potential wear resistant piston ring coating because it exhibited low friction and wear coefficients running against the zirconia counterface. In addition, it should not require machining after application to obtain the desired surface finish, offering a potential cost advantage over a plasma sprayed coating.

Excellent friction and wear results were obtained with the LTAVD chrome nitride coating running against either the zirconia or $440 \mathrm{C}$ stainless steel counterfaces. These promising results make this coating a candidate wear coating for cylinder liners. In addition, the unique LTAVD application process enables the chrome nitride coating to be uniformly applied to the bores of components.

\subsection{Optimization of Coatings for Wear and Friction}

\subsubsection{Description of Hohman A-6 Friction and Wear Test Procedure}

The Hohman A-6, Double Rub Shoe Machine was selected for the optimization of the most promising wear resistant coatings identified from the pin-on-disk screening. The Hohman A-6 has been used in laboratories for 35 years for evaluation of coatings. In general, the Hohman A-6 test (Figure 3.4.1) loads two coated shoe specimens against the circumference of a coated rotating disk specimen. Area contact is obtained by designing the shoes to conform to the surface of the disk. In this program, the candidate piston ring wear coatings were applied to the inner diameter of both shoes while the candidate cylinder liner coatings were applied to the outer diameter of the disks.

All the Hohman testing was performed at $350 \mathrm{C}$ under lubricated conditions. This test temperature was obtained by surrounding the specimens with electric resistant heating elements embedded within insulating blocks to maintain the desired $350 \mathrm{C}$ temperature. 
An 89 Newton normal load was applied with a surface velocity of $3.4 \mathrm{~m} / \mathrm{sec}$. An experimental synthetic lubricant from Lubrizol was used for all the friction and wear optimization. The lubricant was delivered to the coated shoes by a peristaltic pump at a rate of $3 \mathrm{ml} / \mathrm{min}$. through two hypodermic syringes, placed on either side of the shaft, to allow the lubricant to drip uniformly onto the contact surfaces.

Figure 3.4.1

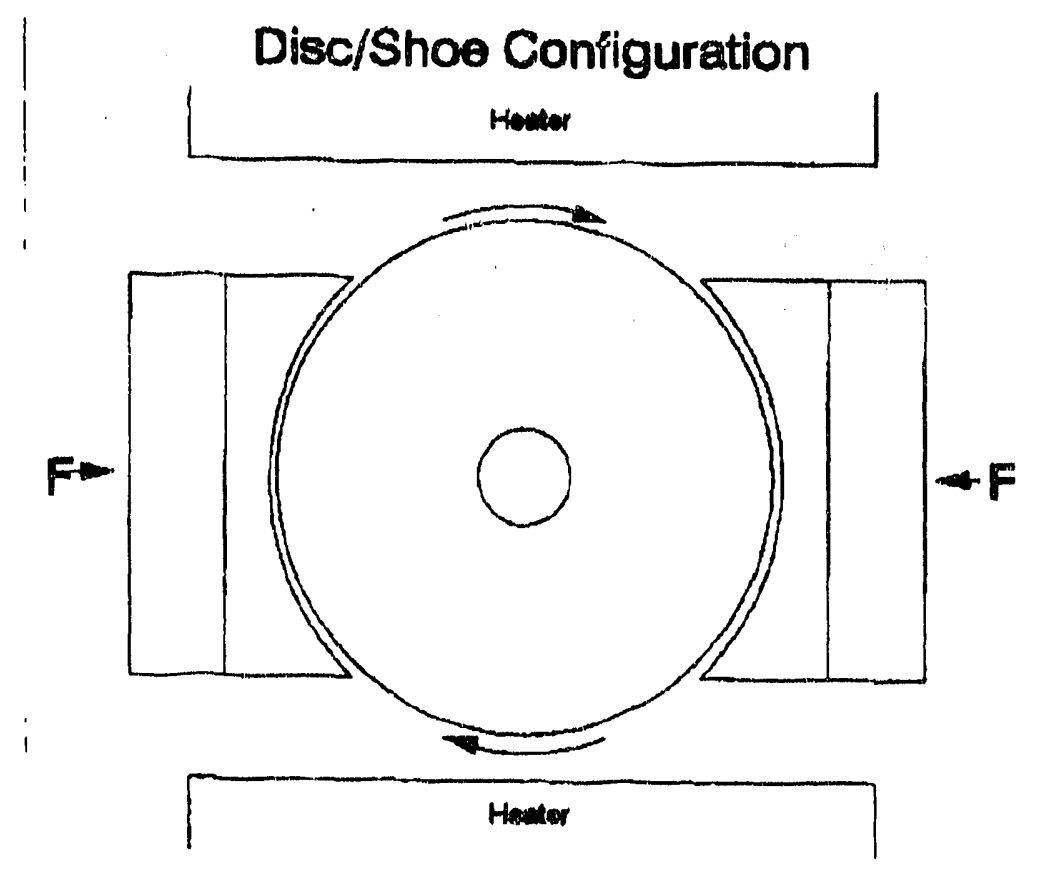

The criteria used for selecting the candidate piston ring or cylinder liner coating pairs was:

1. The ablilty of the process used for applying the coating to coat the desired surface configuration (i.e., I.D. of a cylinder liner or the O.D. of a piston ring),

2. The coating can be applied to the metallic substrate using a process which will not degrade the mechanical properties of the substrate,

3. The coating will have tensile pull adherence valves above $9.7 \mathrm{MPa}$ when applied to cast iron, for cylinder liner candidates, and $\mathrm{H}-13$ tool steel or 17-4 PH stainless steel for piston ring candidates and,

4. The pin-on-disk friction and wear results run against both the metallic and ceramic counterfaces.

The following wear resistant piston ring coatings were selected to be evaluated against candidate cylinder liner coatings: the plasma sprayed high carbon iron-molybdenum blend, 
the plasma sprayed chromia-silica comosite, the NASA self-lubricating PS212 and the mid-temperature chemical vapor deposited titanium carbo-nitride. Wear resistant cylinder liner coatings selected included the plasma sprayed high carbon iron-molybdenum blend, the plasma sprayed chromia-silica composite and the low temperature arc vapor deposited chrome nitride.

\subsubsection{Friction and Wear Test Results}

After selection of the candidate piston ring and cylinder liner coatings, a Hohman A-6 test matrix was developed for optimization of the friction and wear properties of each piston ring/cylinder liner pair. The test matrix consisted of running the four candidate piston ring coatings against each of the three candidate cylinder liner coatings. This test matrix consisted of 12 coating pairs. Tables $3.4 .1,3.4 .2$, and 3.4 .3 contain the results of the Hohman A-6 friction and wear optimization.

Running plasma sprayed high carbon iron-molybdenum coated rub shoes against a plasma sprayed chromia-silica coated disk (Table 3.4.1) produced coefficient of friction values below 0.15 and wear coefficients ranging from 2.3 to $0.4 \times 10^{-8} \mathrm{~mm}^{3} / \mathrm{N}-\mathrm{m}$ for the shoes and from 2.43 to $14.2 \times 10^{-8} \mathrm{~mm}^{3} / \mathrm{N}-\mathrm{m}$ for the disks. The Hohman test results obtained from this this coating pair showed that this piston ring/cylinder liner coating pair would meet the program goals for both friction and wear.

Scanning electron photomicrographs of the surfaces, after 900 hours of Hohman A-6 friction and wear testing, of one set of the high carbon iron-molybdenum rub shoes and the corresponding chromia-silica coated disk are contained in Figures 3.4.2.A and 3.4.2.B. These photomicrographs show that the during the test, the sliding motion of the rub shoes over the disk developed tensile stresses within these coatings and these tensile stresses initiated shallow subsurface cracking. The average wear coefficient was less than $10^{-8}$ $\mathrm{mm}^{3} / \mathrm{N}-\mathrm{m}$.

Coefficient of friction values of above 0.2 were obtained by running plasma sprayed PS 212 rub shoes against a plasma sprayed chromia-silica disk. These high coefficient of friction values, in turn, caused high PS 212 wear coefficients and, for this reason, this coating pair ran only 480 hours before the chromia-silica coating completely wore through the PS 212 . Table 3.4.1 lists average wear coefficients of $9.11 \times 10^{-9}$ for the chromia-silica and $1.70 \mathrm{x}$ $10^{-7} \mathrm{~mm}^{3} / \mathrm{N}-\mathrm{m}$ for the PS2 12 coatings. Scanning electron photomicrographs of this coating pair after testing, Figures 3.4.3.A and 3.4.3.B, showed extensive galling on both PS2 12 coated rub shoes but very little wear on the corresponding chromia-silica disk. Thus, during the test, the chromia-silica coating abraded the solid lubricants located within the chrome carbide matrix. Although the solid lubricants were abraded during the test, there was no significant decrease in friction coefficient. 
Table 3.4 .1

Hohman A-6 Friction and wear Results

Candidate piston Ring Coatings Run hgainst

Chromia-silica coated Cylinder Iner Coating

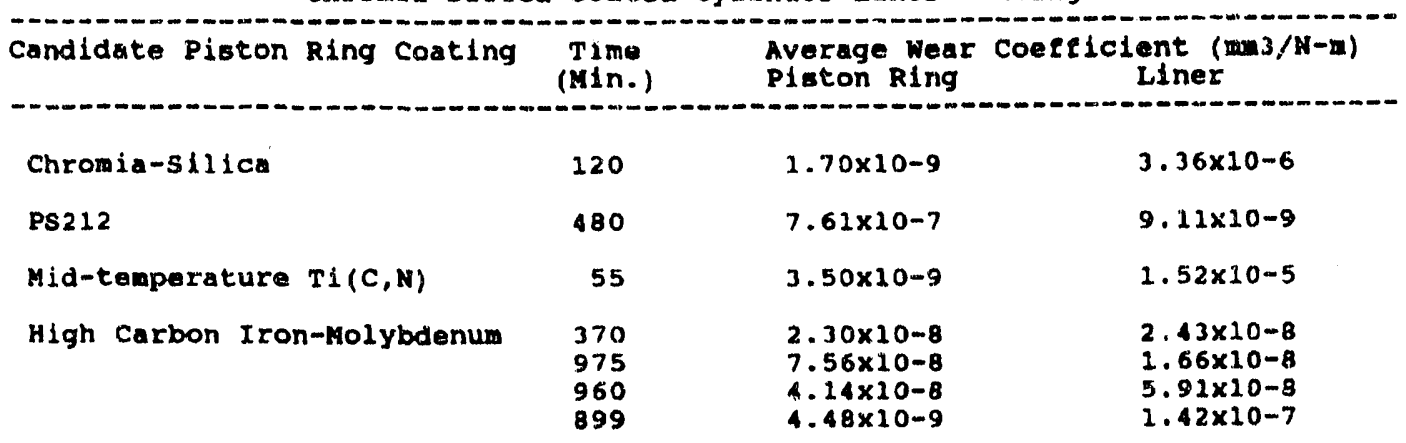

SUMLARY

-The High Carbon Iron-Molybdenum piston ring coating running against the chroina-silica cylinder liner palr was the only coating pair which met the program wear coersiclent goale.

-Unacceptable Chromia-silicate wear was obsarved when this cylinder 1 iner

coating was run against either the chromia-silica or Mid-temperature

$T i(C, N)$ piston ring coatings.

-Unacceptable PS212 piston ring coating wear occurred when this coating was run against the chromia-silica coating.

Table 3.4 .2

Hohman A-6 Friction and Hear Results Candidate Piston Ring Coatings Run Against a LTAVD Chrome Nitrlde Cylinder uiner coating

\begin{tabular}{|c|c|c|c|}
\hline Candidate Piston Ring coating & $\begin{array}{l}\text { Time } \\
\text { (Min.) }\end{array}$ & $\begin{array}{l}\text { Average Weax } \\
\text { Plston Ring }\end{array}$ & $\begin{array}{l}\text { Coefficient }(\operatorname{man} 3 / \mathrm{N}-\mathrm{m}) \\
\text { Liner }\end{array}$ \\
\hline Chromia-silica & $\begin{array}{l}8 \\
5\end{array}$ & $\begin{array}{l}2.27 \times 10-8 \\
2.17 \times 10-7\end{array}$ & $\begin{array}{l}9.36 \times 10-7 \\
6.95 \times 10-6\end{array}$ \\
\hline PS212 & 120 & $7.86 \times 10-9$ & $1.04 \times 10-4$ \\
\hline Mid-temperature $\mathrm{Ti}(\mathrm{C}, \mathrm{M})$ & $\begin{array}{r}6 \\
5 \\
30\end{array}$ & $\begin{array}{l}1.72 \times 10-7 \\
2.95 \times 10-7 \\
4.03 \times 1.0-9\end{array}$ & $\begin{array}{l}1.05 \times 10-6 \\
6.35 \times 10-6 \\
7.72 \times 10-6\end{array}$ \\
\hline High Carbon Iron-Molybdenum & $\begin{array}{l}120 \\
650 \\
375\end{array}$ & $\begin{array}{l}1.23 \times 10-9 \\
2.85 \times 10-8 \\
7.16 \times 10-8\end{array}$ & $\begin{array}{l}3.13 \times 10-7 \\
1.92 \times 10-8 \\
1.48 \times 10-8\end{array}$ \\
\hline
\end{tabular}

SURAMAY

-The High Carbon Iron-Molybdenum running against the chrome Nitride was the only coating palr which met the programs wear coefficient goals.

-Unacceptable Chrome Nitride wear was observed running against the following candldate piston ring coatings: PS212, Chromia-silica, and MLd-temperature $\mathrm{Ti}(\mathrm{C}, \mathrm{N})$. 
FIGURE 3.4.2A

SLRFACES AFTER HOHMAN A.6 TESTING

TEST 44.-PL ASMA SPRAYED HIGH CARBON IRON-MOLYBDENUM

COATHD SHOES RLNNING AGAINST A

PLASMA SPRAYED CHROMIA-SILICA DISK

\section{CHROMIA.SILICA DISK}

MAGNIFICATION 100X

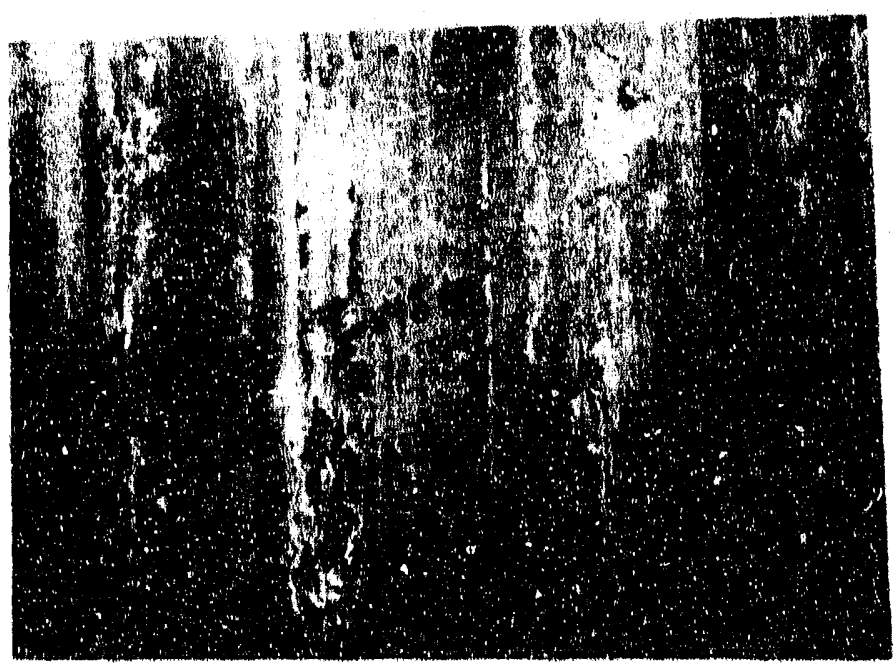

REGION 045 MAGNIFICATION $500 \mathrm{X}$

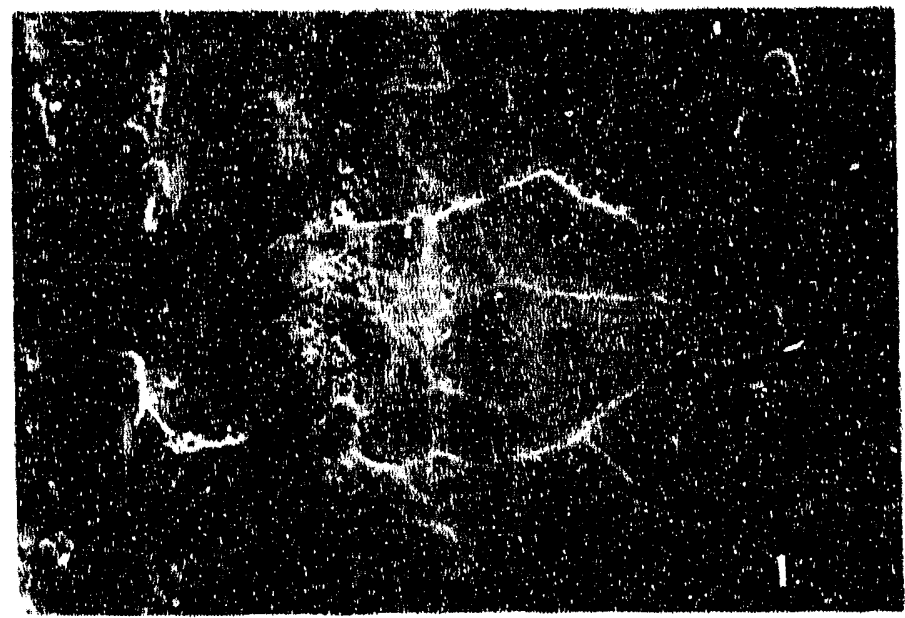


FIC:URE 3.4.2B

SURFACES AFTER HOHMAN A-6 TESTING

TEST 44-.PI ASMA SPRAYED HIGH CARBON IRON-MOLYBDENUM

COATED SHOES RUNNING AGAINST A

PLASMA SPRAYFD CHROMIA-SILICA DYSK

\section{HIGH CARBON IRON-MOLYBDENUM SHOES}

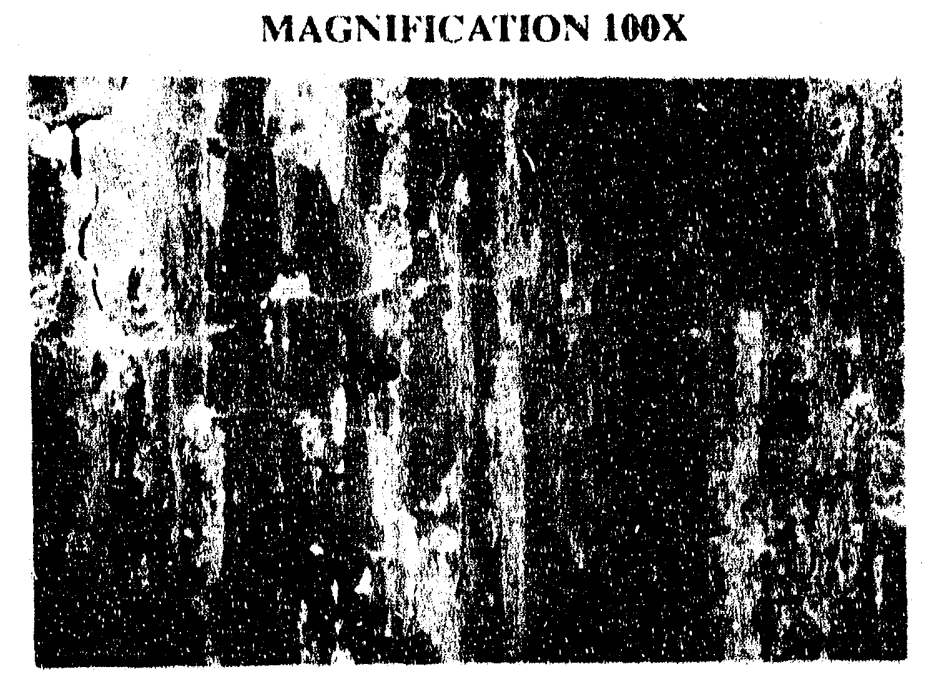

REGION 110 MAGNIFICATION 500X

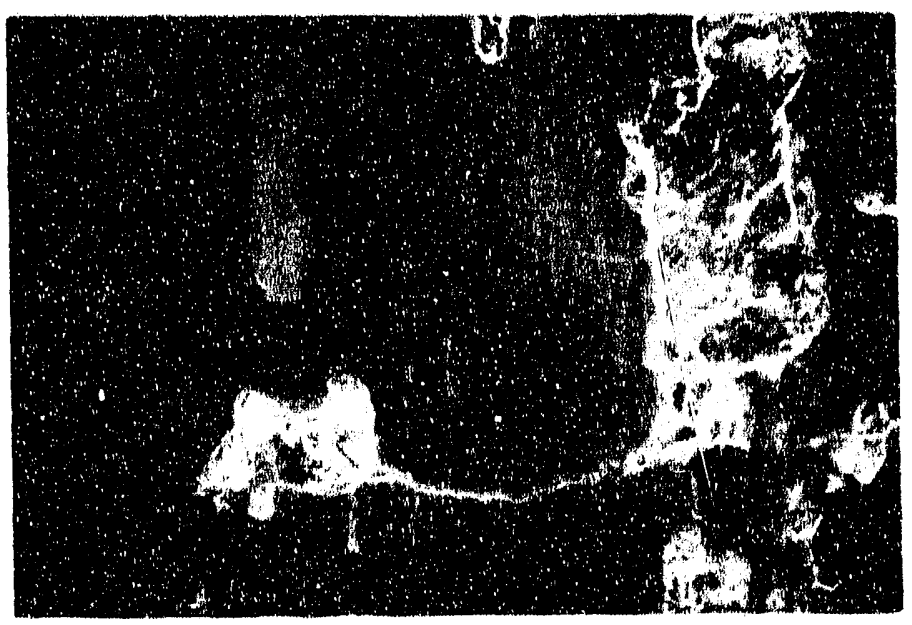


FIGURE 3.4.3A

SURFACES AFTER HOHMAN A-6 TESTING

TEST 45--PI ASMA SPRAYED PS212 SHOES RUNNING

AGAINST A PLASMA SPRAYED CHROMIA-SILICA COATED DISK

CHROMIA-SILICA DISK

MAGNIFICATION 100X

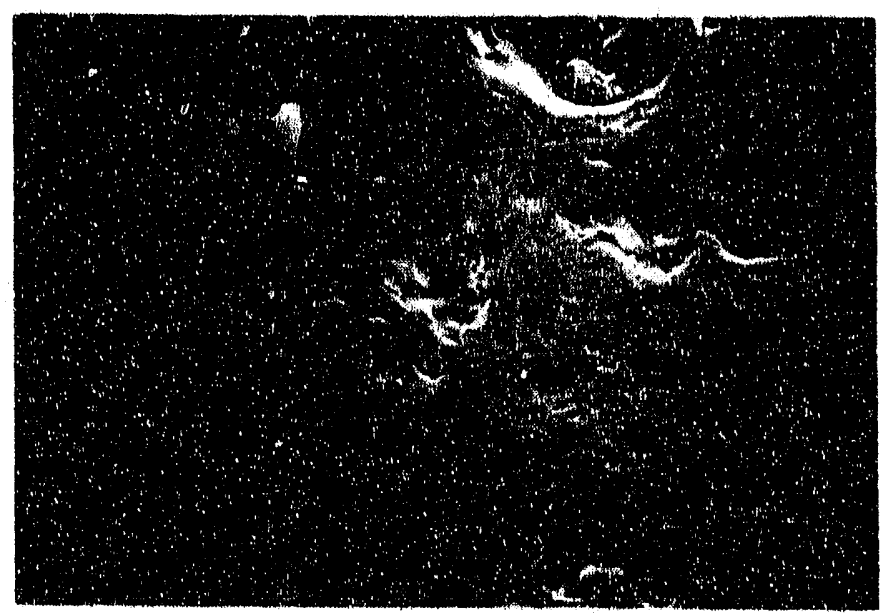

MAGNIFICATION 500X

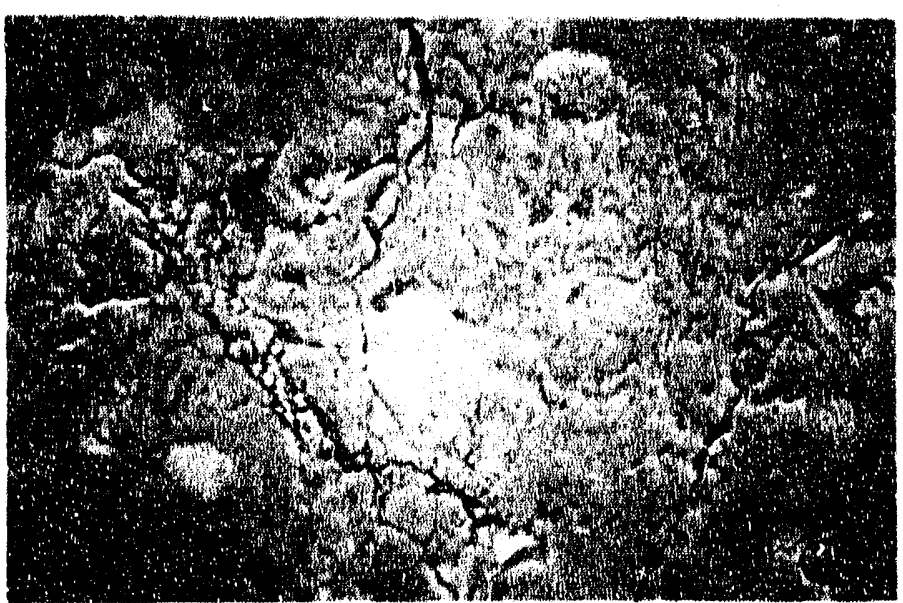


FIGURE 3.4.3B

SURFACES AFTER HOHMAN A.6 TESTING

TEST 45-.PLASMA SPRAYED PS212 SHOES RUNNING

AGAINST A PLASMA SPRAYED CHROMIA-SILICA COATED DISK

\section{PS212 COATED SHOES}

MAGNIFICATION 100X

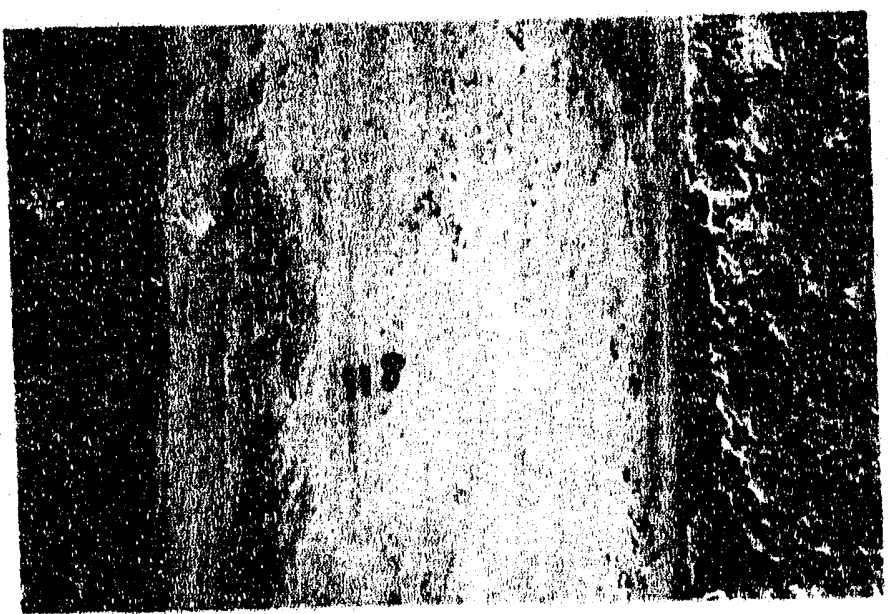

MAGNIFICATION 500X

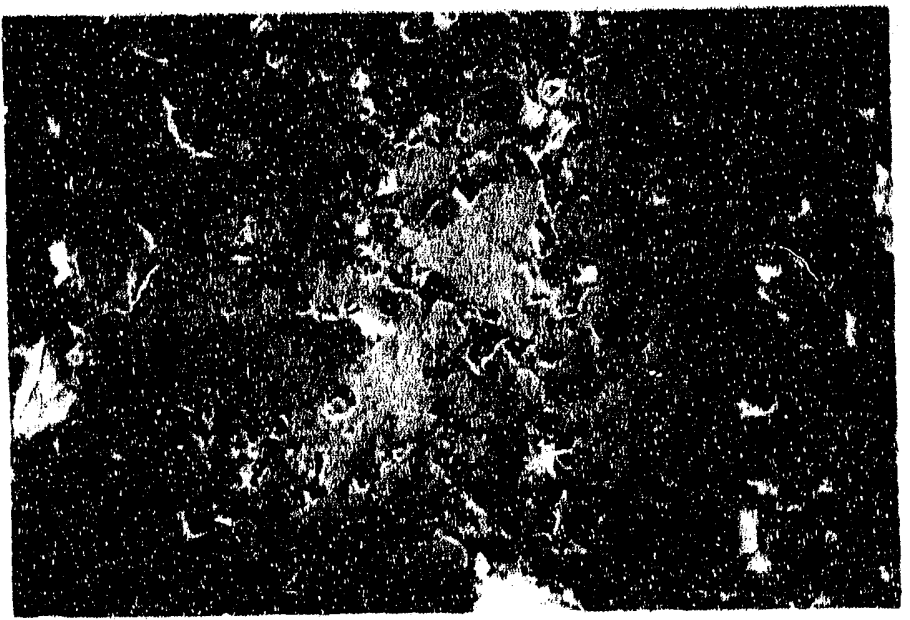




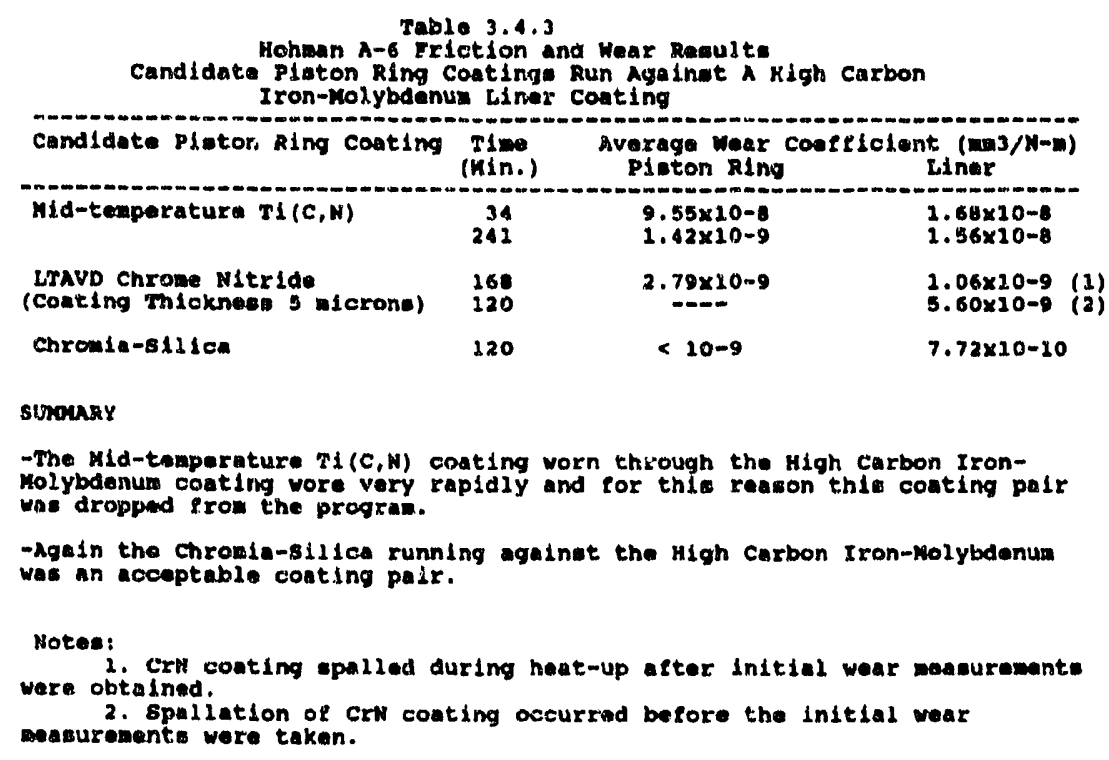

Running plasma sprayed chromia-silica or mid-temperature chemical vapor deposited titanium carbonitirde coated rub shoes against the plasma sprayed chromia-silica coated disks produced friction coefficients above 0.2 and average disk wear coefficients ranging from $10^{-5}$ to $10^{-6} \mathrm{~mm}^{3} / \mathrm{N}-\mathrm{m}$, respectively. Both the friction and disk wear coefficients for both these coating pairs were above the program goals.

Scanning electron photomicrographs of these coating pairs, after testing, are contained in Figures 3.4.4 and 3.4.5. These photomicrographs showed extensive cracking and large regions of coating delamination on both the chromia-silica disks. A lesser amount of cracking and coating delamination was observed on the corresponding chromia-silica or titanium carbonitride coated rub shoes.

Another coating pair which met the program's friction and wear goals was plasma sprayed high carbon iron-molybdenum rub shoes running against a low temperature arc vapor deposited (LTAVD) chrome nitride coated disk (Table 3.4.2). This coating pair had coefficient of friction values below 0.15 and, in three tests, had average wear coefficients which ranged from $1.23 \times 10^{-9}$ to $7.16 \times 10^{-8} \mathrm{~mm}^{3} / \mathrm{N}-\mathrm{m}$ for the high carbon iron-molybdenum coated shoes and from $3.13 \times 10^{-7}$ to $1.48 \times 10^{-8} \mathrm{~mm}^{3} / \mathrm{N}-\mathrm{m}$ for the chrome nitride coated disk.

The scanning electron photomicrographs of this coating pair after 650 hours of testing, are contained in Figures 3.4.6.A and 3.4.6.B. Extensive cracking and smearing were characteristic of the high carbon iron-molybdenum coating after testing. Also observed within the coating were small isolated regions where sorne coating delamination had occurred. Very little chrome nitride coating was present on the disk after testing. 
FIGURE 3.4.4A

SURFACES AFTER HOHMAN A.6 TESTING

TEST 42-.PLASMA SPRAYED CHROMIA-SILICA COATED SHOES RUNNING AGAINST A PLASMA SPRAYED CHROMIA-SILICA DISK

\section{CHROMIA-SILICA COATED DISK}

MAGNIFICATION 100X

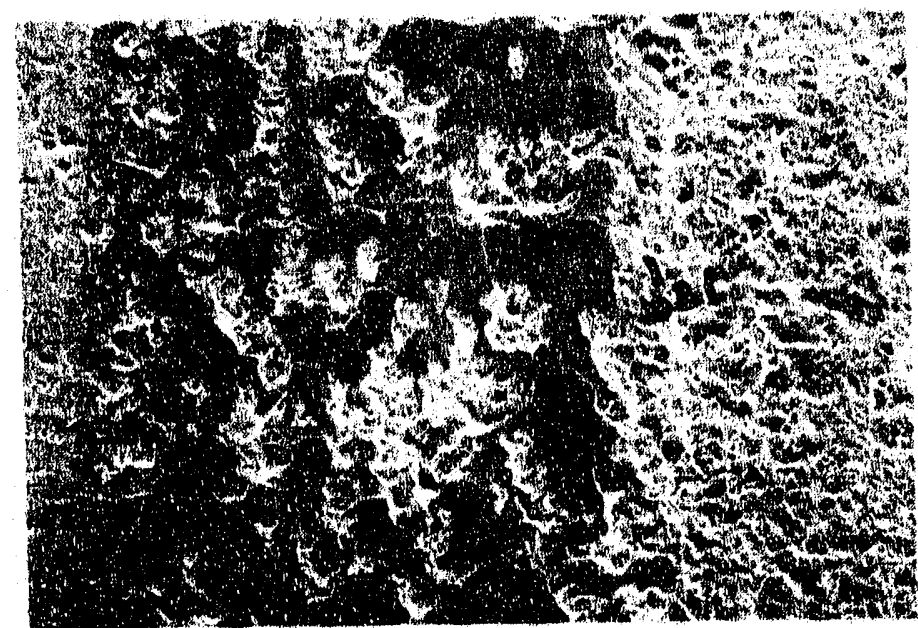

MAGNIFICATION 500X

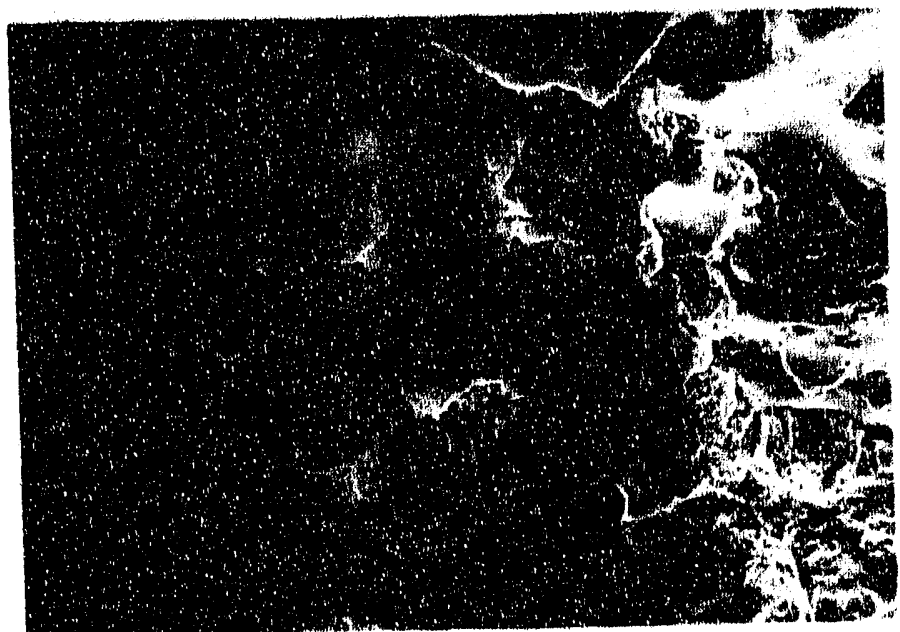


FIGURE 3.4.4B

SURFACES AFTER HOHMAN A.6 TESTING

TEST 42.-PLASMA SPRAYED CHROMIA-SILICA COATED SHOES

RUNNING AGAINST A PLASMA SPRAYED CHROMIA-SILICA DISK

\section{CHROMIA-SILICA COATED DISK}

\section{MAGNIFICATION 50X}

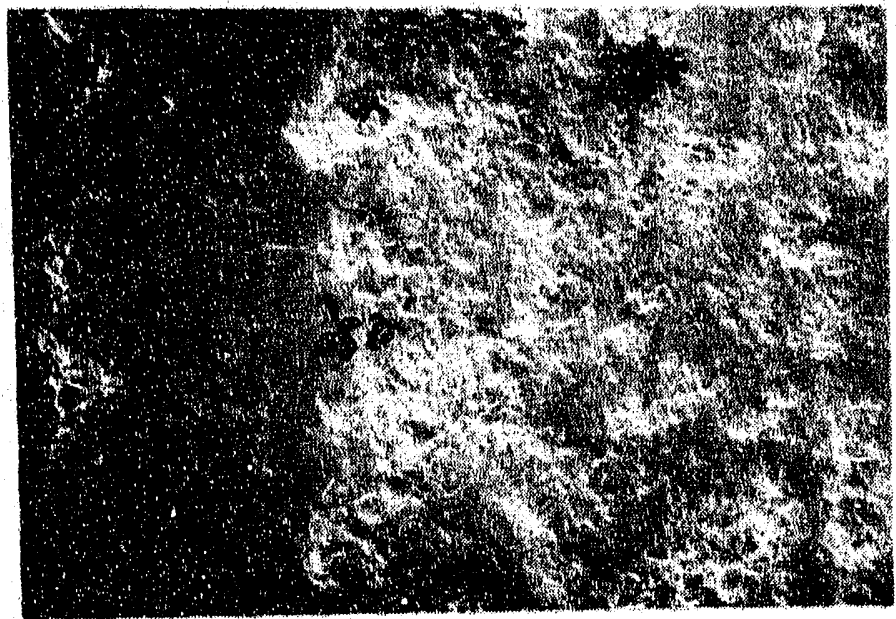

REGION 052 MAGNIFICATION 500X

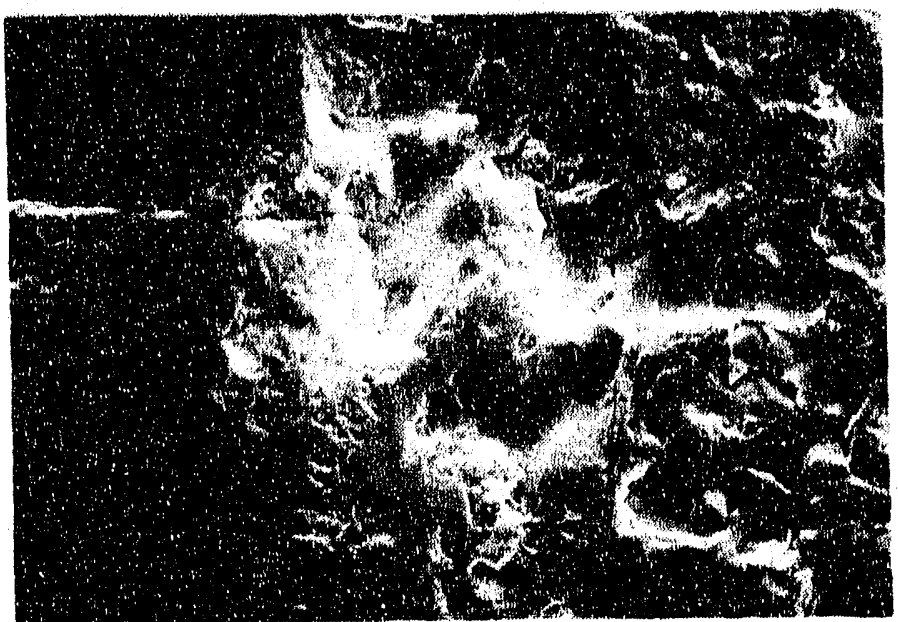


FIGURE 4.3.5A

SURFACES AFTER HOHMAN A-6 TESTING

TEST 49.-MID-TEMPERATURE Ti (C,N) CVD COATED SHOES RUNNING AGAINST A PLASMA SPRAYED CHROMIA-SILICA COATED DISK

\section{CHROMIA-SILICA DISK}

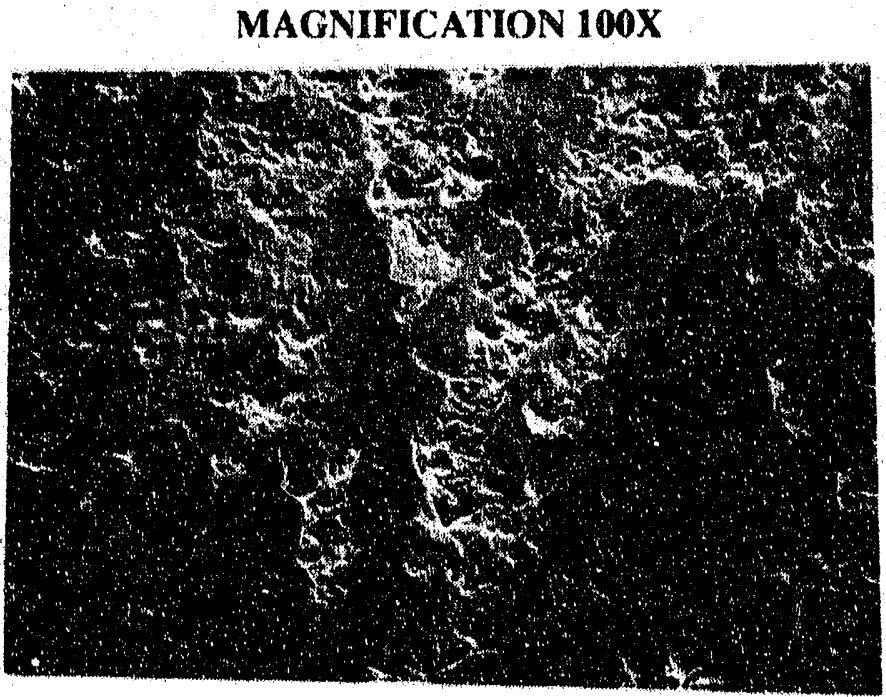

REGION 013 MAGNIFICATION 500X

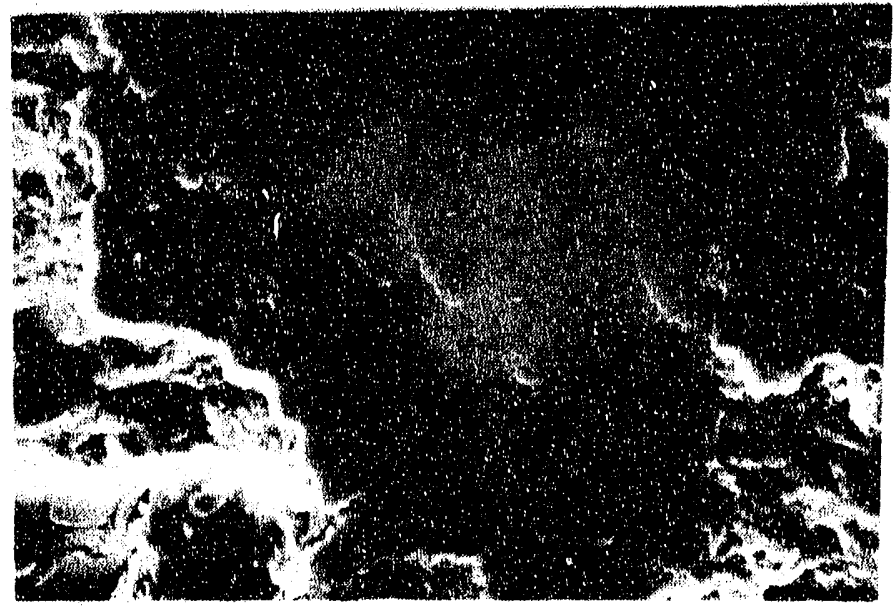


FIGURE 4.3.5B

SURFACES AFTER HOHMAN A-6 TESTING

TEST 49-.MID-TEMPERATURE Ti (C,N) CVD COATED SHOES RUNNING

AGAINST A PLASMA SPRAYED CHROMIA-SILICA COATED DISK

\section{CHROMIA-SILICA DISK}

MAGNIFICATION 100X

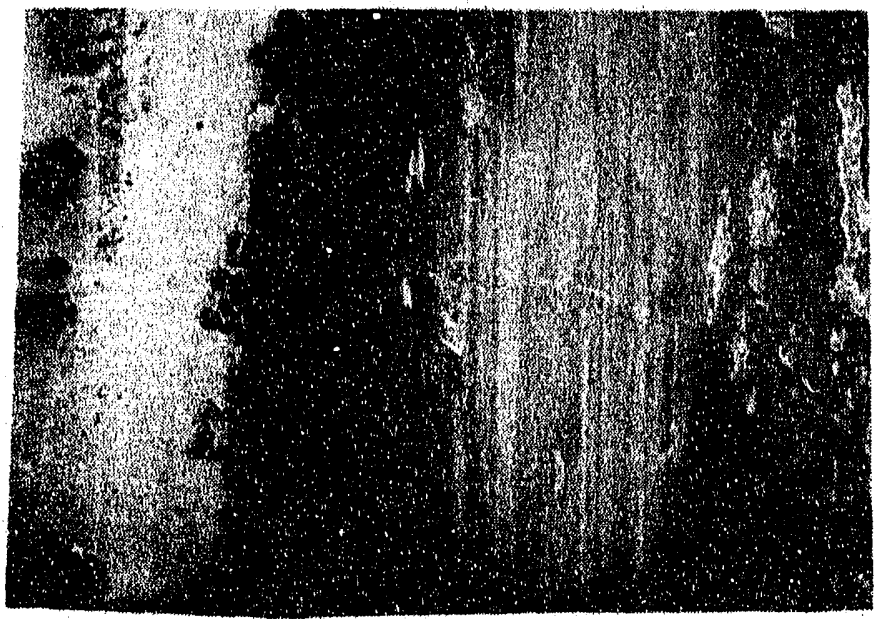

REGION 57 MAGNIFICATION 500X

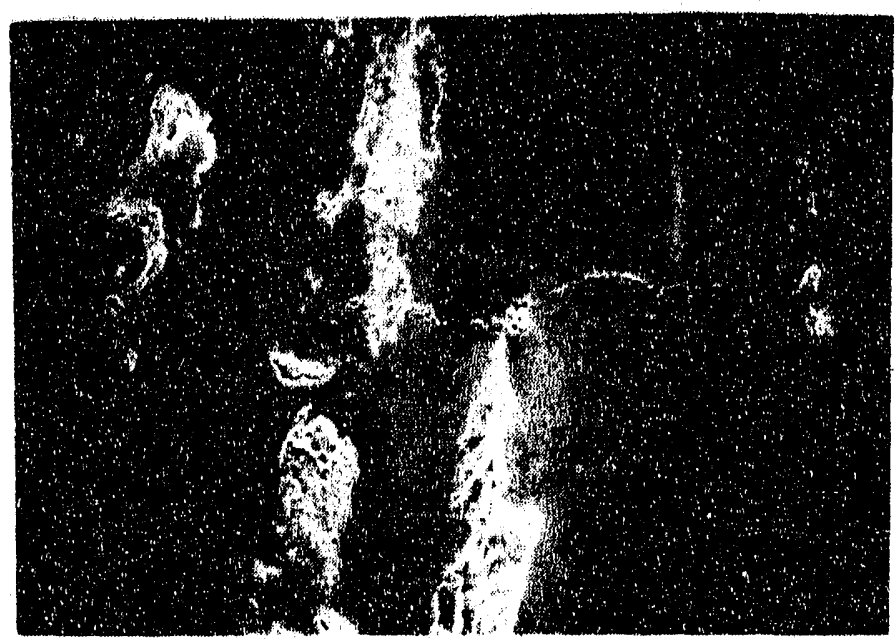


FIGURE 3.4.6A

SURFACES AFTER HOHMAN A-6 TESTING

TEST 45-..PLASMA SPRAYED HIGH CARBON IRIONAMOLYBDENUM SHOES R.UNNING AGAINST A LTAVD CHROME NITRIDE COATED DISK

$$
\text { CHROME NITRIDE COATED DISK }
$$

MAGNIFICATION 100X

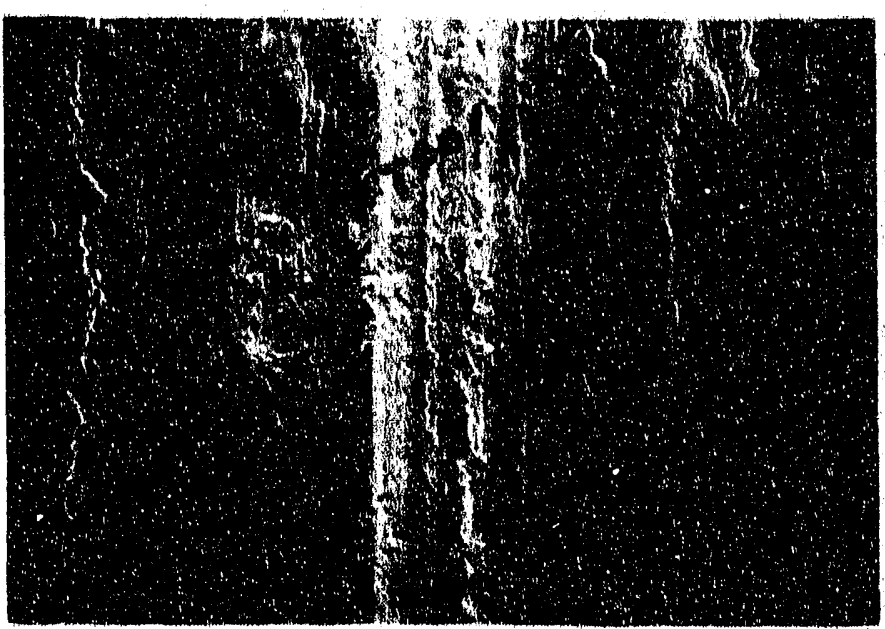

REGION 001 MAGNIFICATION 500X

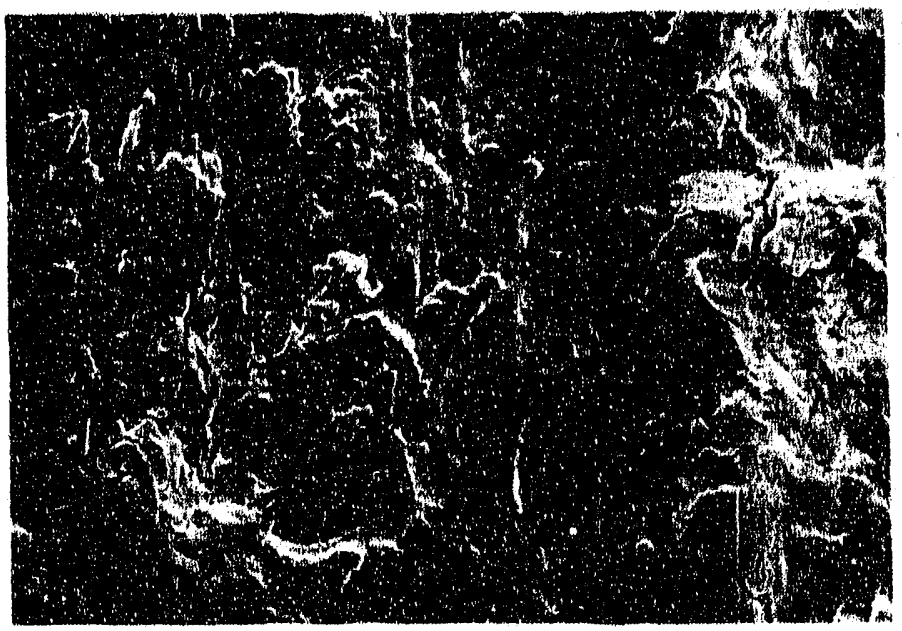


FIGURE 3.4.6B

SURFACES AFTER HOHMAN A-6 TESTING

TEST 43--PLASMA SPRAYED HIGH CARBON IRON-MOLYBDENUM SHOES RUNNING AGAINST A LTAVD CHROME NITRIDE COATED DISK

HIGH CARBON IRON-MOLYBDENUM COATED SHOES

MAGNIFICATION 100X

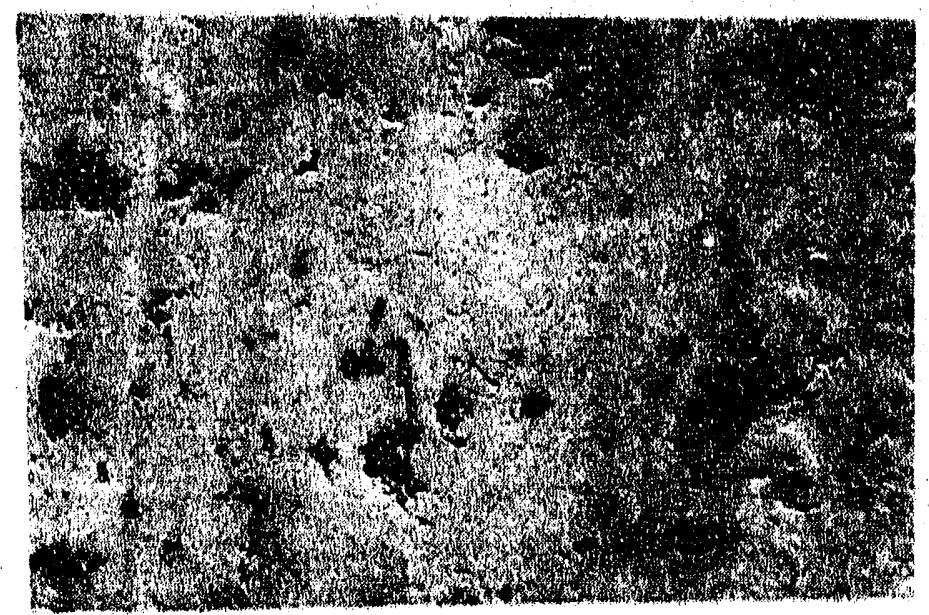

REGION 067 MAGNIFICATION 500X

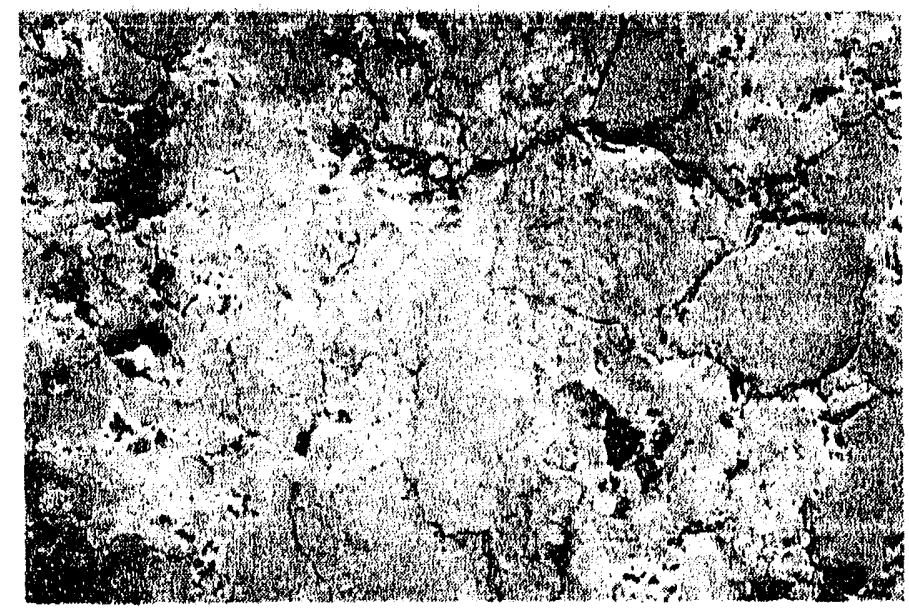


Running either plasma sprayed chromia-silica or mid-temperature titanium carbonitride CVD rub shoes against the LTAVD chrome nitride coated disk resulted in coefficient of friction values above 0.20 and very high chrome nitride average wear coefficients $\left(10^{-6}\right.$ $\left.\mathrm{mm}^{3} / \mathrm{N}-\mathrm{m}\right)$. For this reason, these tests were terminated after only 5-30 minutes of testing because the shoes wore completely through the chrome nitride coating. Scanning electron photomicrographs of one set of these specimens (Figures 3.4.7.A and 3.4.7.B), after testing, showed very little wear on the mid-temperature titanium carbonitride rub shoes, while the chrome nitride coating was completely worn from the disk.

Average disk wear coefficie/ts of $1.04 \times 10^{-4} \mathrm{~mm}^{3} / \mathrm{N}-\mathrm{m}$ were obtained running plasma sprayed PS 212 coated rub shoes against a chrome nitride coated disk. This wear coefficient was well above the desired $10^{-8} \mathrm{~mm}^{3} / \mathrm{N}-\mathrm{m}$ wear coefficient of this program. High friction coefficients were the probable reason for the poor average wear coefficient of the PS 212 .

The Hohman friction and wear results for the mid-temperature titanium carbonitride, LTAVD chrome nitride and chromia-silica coated rub shoes running against plasma sprayed high carbon iron-molybdenum coated disks are contained in Table 3.4.3. Running the mid-temperature titanium carbonitride rub shoes against the high carbon iron-molybdenum disk resulted in friction coefficients of below 0.15 , and average wear coefficients of $1.42 \times 10^{-9}$ to $9.55 \times 10^{-8} \mathrm{~mm}^{3} / \mathrm{N}-\mathrm{m}$ for the titanium carbo-nitride coated shoes and $1.56 \times 10^{-8}$ to $1.86 \times 10^{-8} \mathrm{~mm}^{3} / \mathrm{N}$-m for the high carbon iron-molybdenum shoes. These results indicate that this coating pair will meet the friction and wear goals of this program.

Wear testing of the 5 micron thick chrome nitride coated rub shoes against the high carbon iron-molybedenum coated disks could not be completed because of chrome nitride coating spallation. The first instance of spallation occurred during a heat-up cycle after the test was stopped to obtain an initial set of wear measurements. Prior to the castrophic coating failure both the rub shoe and disk had average wear coefficients of $10^{-9} \mathrm{~mm}^{3} / \mathrm{N}-\mathrm{m}$. The second instance of coating spallation occurred prior to testing when the rub shoes were heated to the $350 \mathrm{C}$ test temperature.

Friction coefficients below 0.15 and average wear coefficients of less than $10^{-9} \mathrm{~mm}^{3} / \mathrm{N}-\mathrm{m}$ were obtained for both the rub shoes and the disk running plasma sprayed chromia-silica rub shoes against a high carbon iron-molybdenum disk. The friction and wear coefficients obtained from this coating pair were similar to those obtained running high carbon ironmolybdenum shoes against a chromia-silica disk (Table 3.4.1). 
FIGURE 3.4.7A

SURFACES AFTER HOHMAN A-6 TESTING

TEST 50--MID-TEMPERATURE TI (C,N) COA'TED SHOES RUNNING AGAINST A LTAVD CHROME NITRIDE COATED DISK

\section{CHROME NITRIDE COATED DISK}

MAGNIFICATION 100X

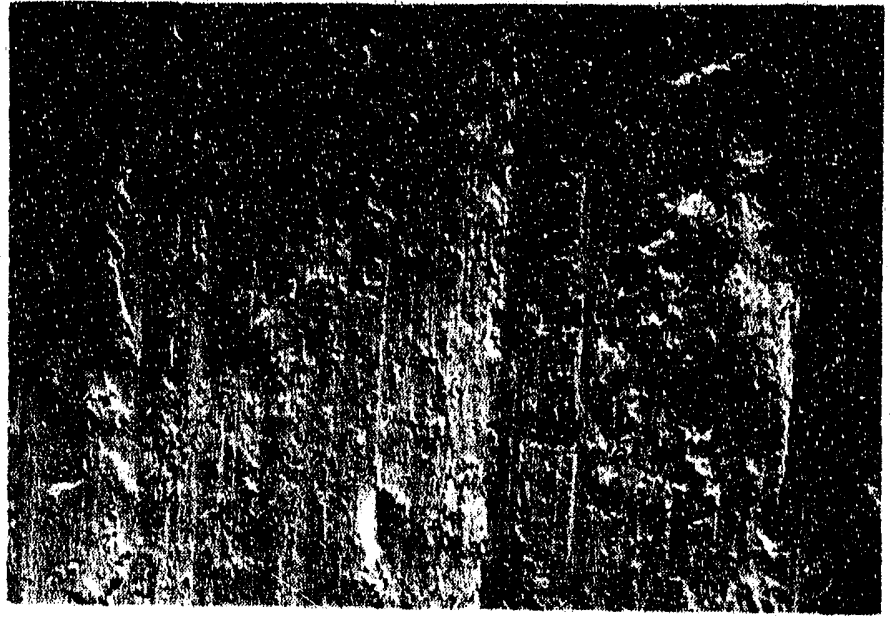

MAGNIFICATION 500X

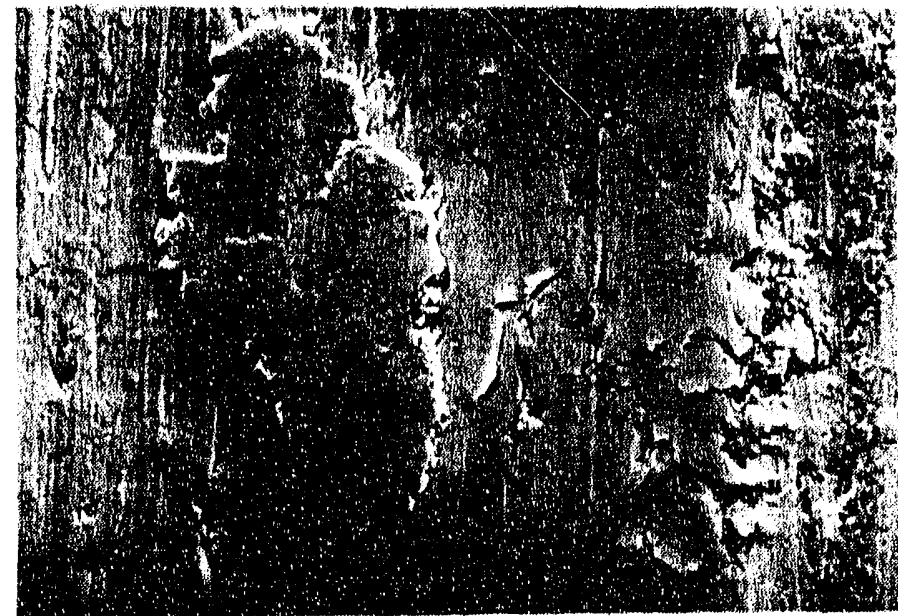


FIGURE 3.4.7B

SURFACES AFTER HOHMAN A-6 TESTING

TEST 50--MID.'TEMPERATURE TI (C,N) COATED SHOES RUNNING AGAINST A LTAVD CHROME NITRIDE COATED DISK

MID-TEMPERATURE TI (C,N) SHOES

MACNIFICATION 200X

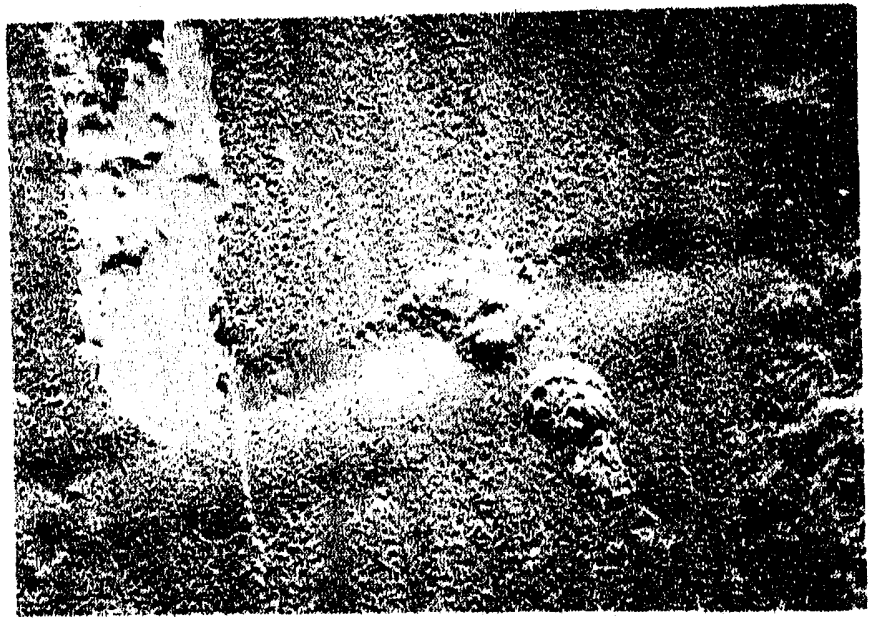

MAGNIFICATION 500X

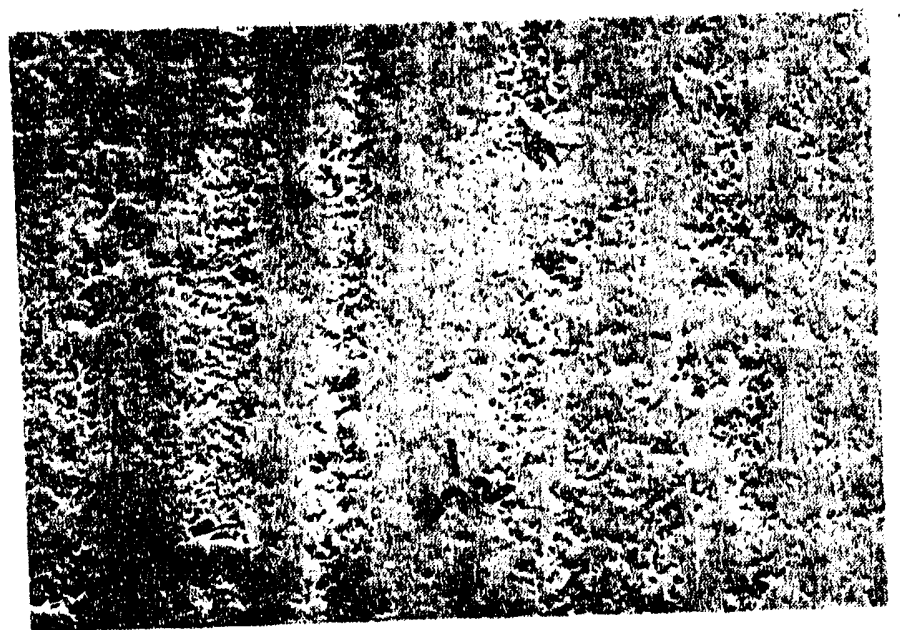




\subsubsection{Selection of Piston Ring/ Cylinder Liner Wear Resistant Coating Pairs Which Meet the Program Goals}

The friction and wear optimization identified two wear resistant piston ring/cylinder liner coating combinations which met both the friction and wear goals of this program. The two coating pairs were:

1. Plasma sprayed high carbon iron-molybdenum coated piston rings and plasma sprayed chromia-silica cylinder liner, and

2. Plasma sprayed high carbon iron-molybdenum coated piston rings and low temperature arc vapor deposited chrome nitride.

Both these coating combinations exhibited coefficient of friction values 0.2 or below and had average wear coefficients of less than $10^{-8} \mathrm{~mm} / \mathrm{N}-\mathrm{m}$.

\subsection{Characterization of Candidate Wear Resistant Piston Ring/Cylinder Liner Coating} Pairs Which Demonstrated Excellunt Friction and Wear Performance

The two wear resistant piston ring and cylinder liner coating pairs identified as meeting the friction and wear goals of this program were next fully characterized for wear, thermal shock resistance and environmental stability in a diese! exhaust atmosphere.

\subsubsection{Development of Wear Curves}

Wear curves were obtained for the high carbon iron-molybdenum running against the chromia-silica and the high carbon iron-molybdenum running against the chrome nitride.

These wear cur as were obtained by running the specimens on the Hohman A-6 Double Rub-Shoe machine, at 350 (), with a norrnal load of $89 \mathrm{~N}$, and a surface velocity of $3.4 \mathrm{~m} /$ sec. During the testing, an experimental synthetic lubricant trom Lubrizol was used. The lubricant was delivered to each shoe surface using a peristaltic pump at a rate of $3 \mathrm{ml} / \mathrm{min}$. After every 120 minutes the test was interrupted to measure the wear on both the shoe and disk surfaces. Wear curves for each coating pair were then developed from these wear measurements. The wear curves for the high carbon iron-molybdenum running against the chromia-silica are contained in Figures 3.5.1 and 3.5.2. Figures 3.5.3 and 3.5.4 contain the wear curves for the high carbon iron-molybdenum running against the chrome nitride.

The wear scar volumes measured on the high carbon iron-molybdenum coated rub shoes atter 980 hours of friction and wear testing against the chromia-silica coated disks were (0.55. (0.27 and 0.05 mm3, for Tests 56, 70), and 72, respectively (Figure 3.5.1). The wear 
scars measured on two of the corresponding chromia-silica coated disks from Tests 56 and 70 were 0.05 and $2.0 \mathrm{~mm}^{3}$. The third chromia-silica coated disk (Test 72) had a wear scar volume greater than $8.0 \mathrm{~mm}^{3}$. However, over 50 percent of the volume of this wear scar occurred after 380 minutes of testing when one of the rub shoes "slipped" off the disk. Eliminating the wear which occurred when the rub shoe "slipped," the volume of the wear scar would have been less than $4.0 \mathrm{~mm}^{3}$. The volumes of the wear scars ineasured on both the shoes and disks after 980 hours of testing indicated that this coating pair, a high carbon iron-molybdenum coated piston ring and a chromia-silica coated cylinder liner, will have wear rates which would meet the commercial durability requirements.

The wear curves obtained from running the high carbon iron-molybdenum coated rub shoes against a low temperature arc vapor deposited chrome nitride coated disk showed that very little wear occurred on either the rub shoes or the disk. One set of high carbon ironmolybdenum shoes exhibited essentially no wear after 680 ) hours of testing (Test 43) while the second set had a $0.2 \mathrm{~mm}^{3}$ wear scar after 380 hours of testing, Test 54 . However, the majority of the wear occurred during the initial 100 hours of testing and after this breakin period very little additional wear was seen on these shoes. The wear scars measured on the corresponding chrome nitride coated disks were $0.1 \mathrm{~mm}^{3}$ or less. Although the wear scars on the chrome nitride disks were very small, the tests had to be terminated after 650 hours and 380 hours because the high carbon iorn-molybdenum coated shoes had worn completely through the 3 micron thick chrome nitride coating. These wear curves show that a three micron thick chrome nitride coating, although it meets the program goals with respect to both friction and wear, will not meet the commercial durability goals. A 15 to 20 micron thick chrome nitride coating is required to meet these commercial durability goals.

Once the wear curves showed that a thicker chrome nitride coating is required a second set of chrome nitride specimens was obtained. These specimens were coated using the same process conditions as the initial specimens except the chrome nitride was applied to a thickness of 5 microns. Wear curves for these specimens could not be obtained because the chrome nitride coating spalled completely from the disk. On one specimen the spallation occurred during the initial heat to $356, \mathrm{C}$ prior to initiating the wear test. The second specimen spalled after after 120 minutes of wear testing during the heat-up to $350 \mathrm{C}$ after the initial set of wear measurements was obtained.

\subsubsection{Oxidation Resistance}

The oxidation resistance of the plasma sprayed high carbon iron-Molybdenum and plasma sprayed chromia-silica coatings was evaluated by exposing coated cast iron Falex disks to 
a simulated diesel exhaust atmosphere, for 500 hours at $400 \mathrm{C}$, in a tube furnace. The simulated diesel atmosphere was obtained from the mixing of various gases. The composition of this simulated diesel exhaust atmosphere was:

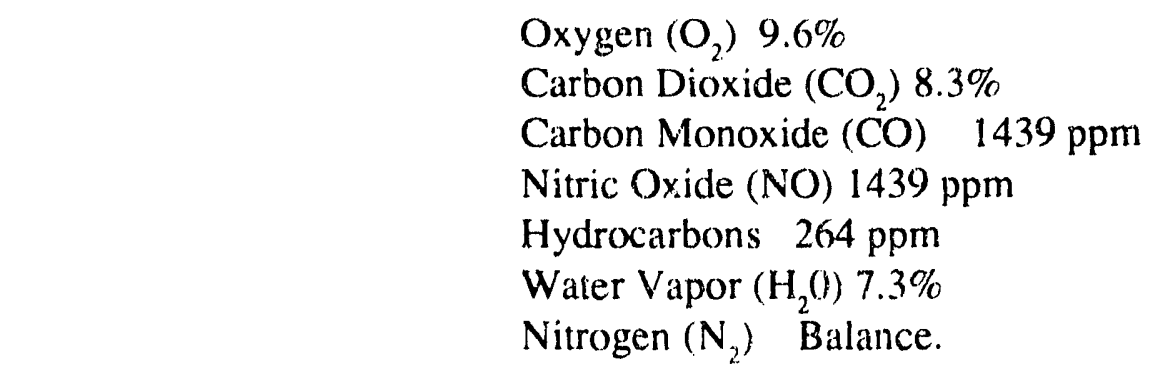

Figure 3.5.1

Wear Curve for High Carbon Iron Molybdenum Shoes Running Against a Chromia-Silica Disk
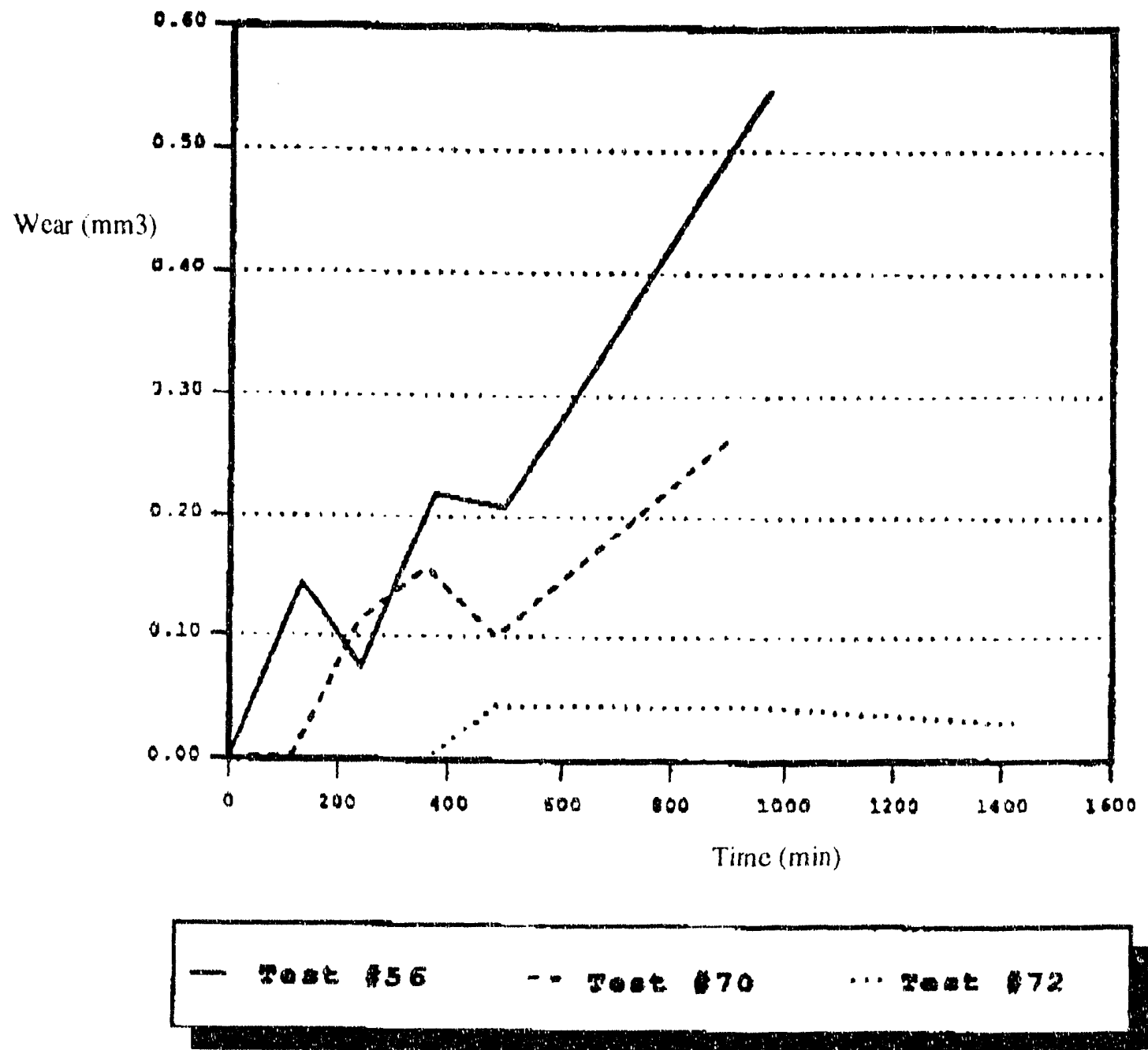
Fìgure 3.5.2

Wear Curve for Chromia-Sillca Disk Run Against High Carbon Iron-Molybdenum Shoes

Wear $(\mathrm{mm} 3)$

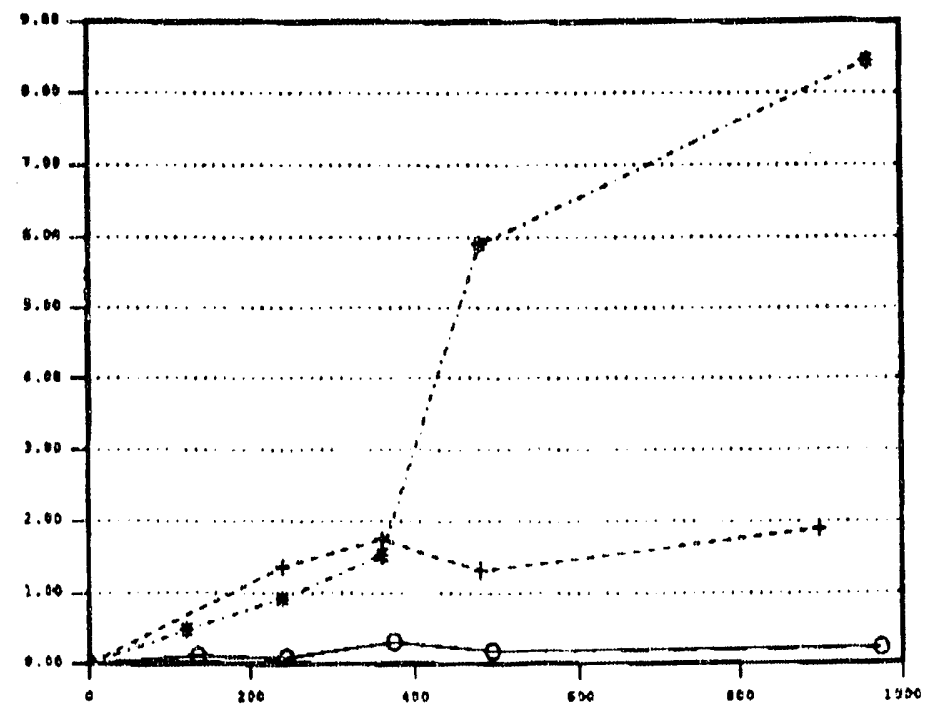

Time ( $\mathrm{min})$

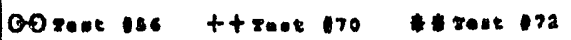

Figure 3.5.3 Wear Curve for High Carbon Iron-Molybdenum Shoes Running Against a Chrome Nitride Disk

Wear $(\mathrm{mm} 3)$

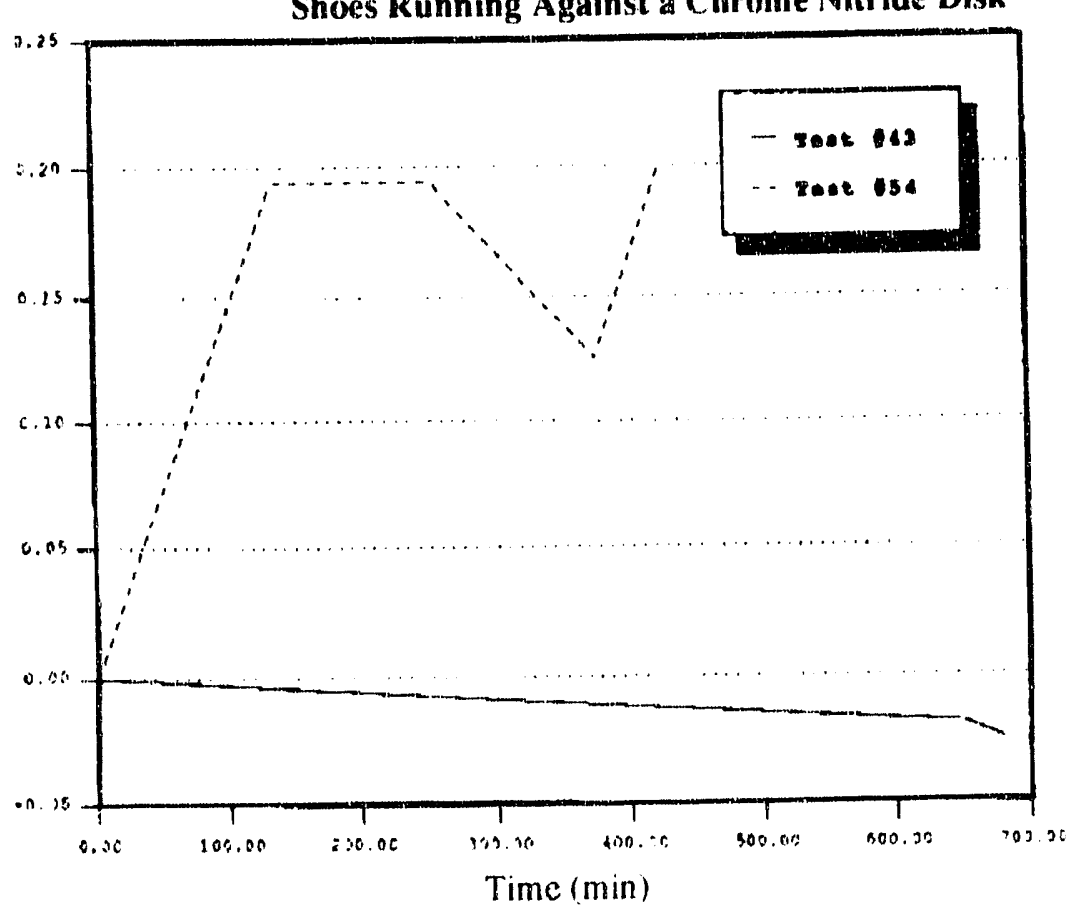




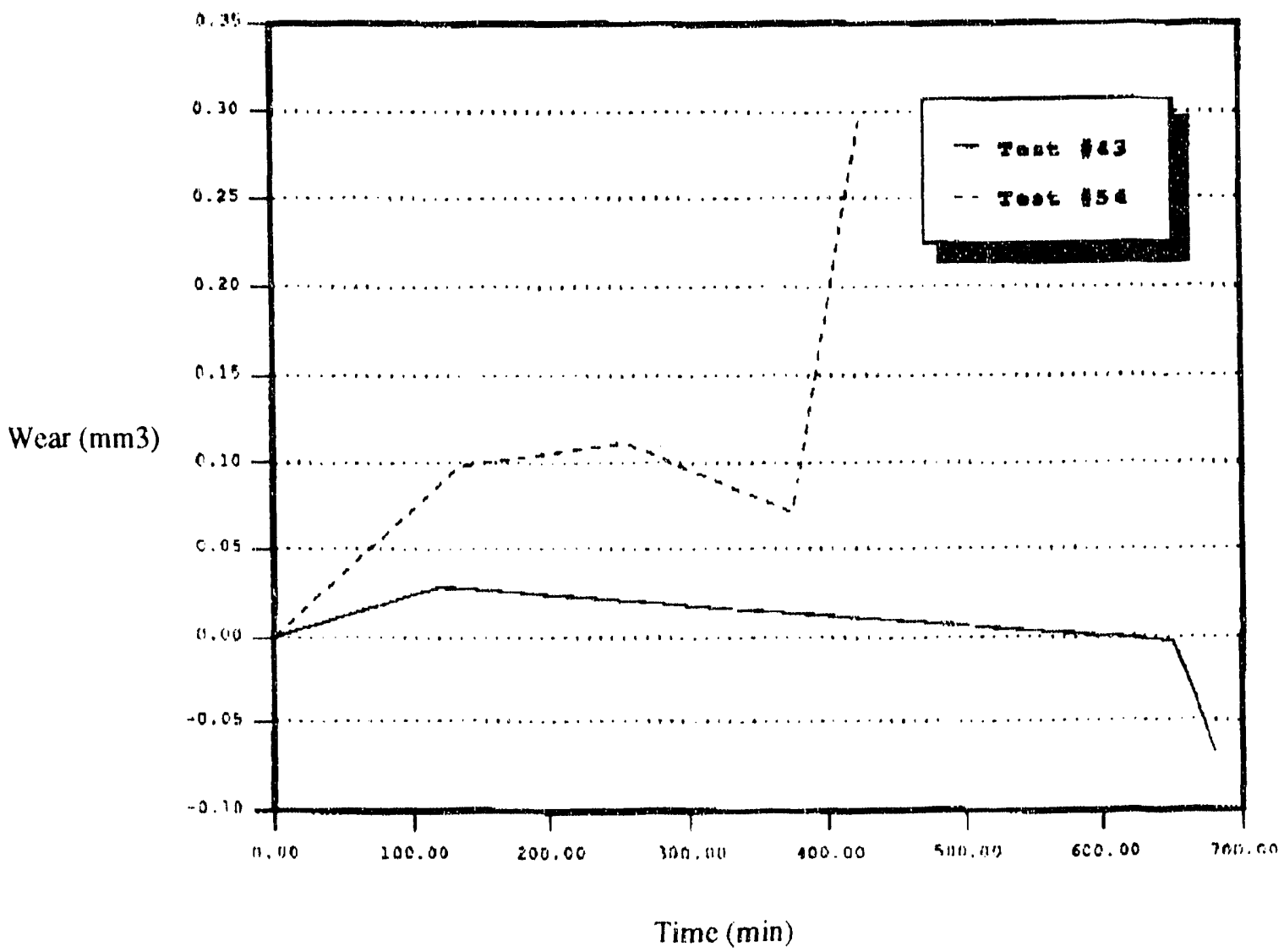

Figure 3.5.4 Wear Curve for Chrome Nitride Disk RunningAgainst High Carbon Iron Shoes

The plasma sprayed chromia-silica coating was not affected by the simulated diesel exhaust atmosphere. No coating spallation or discoloration was observed on any of the five specimens exposed. In fact, the physical appearance of these specimens was identical to the physical appearance of plasma sprayed chromia-silica specimens which had not been exposed to the simulated diesel exhaust atmosphere.

The high carbon iron-molybdenum plasma sprayed coated discolored during the 500 hour exposure to the simulated diesel exhaust atmosphere. This discoloration was caused by oxidation of the iron on the surface of the specimens which was in direct contact with the atmosphere. The oxidation was limited to the very top surface of the coating and for this reason no significant increase in coating thickness or spallation occurred. 


\subsubsection{Thermal Shock Resistance}

The thermal shock resistance of the plasma sprayed high carbon iron-molybdenum and plasma spayed chromia-silica coatings was determined by quenching plasma sprayed cast iron Falex specimens fifty (50) times from $650 \mathrm{C}$ into boiling water. Each specimen was thermocoupled to assure that it attained a $650 \mathrm{C}$ temperature prior to each quench. The thermocouple also illustrated that it took approximately seven seconds for the Falex disks to be quenched from 650 to $100 \mathrm{C}$. Representative photomicrographs of two specimens after completion of the thermal shock testing are contained in Figures 3.5.5 and 3.5.6.

The photomicrographs show that cracks developed in both plasma coatings. These cracks were first noticed after three thermal shock cycles. Although some additional crack propagation occurred during the subsequent thermal shock cycles, no coating disbonding or coating spallation occurred. These photomicrographs also show that the nature of the cracks which developed within each coating was different. The thermal shock testing caused a mud-cracking pattern to develop within the chromia-silica coating (region labeled $\mathrm{M}$ in Figure 3.5.5). Also observed on these specimens was cracking within the cast iron substrate (region labeled A in Figure 3.5.5). The cracks observed within the high carbon iron-molybdenum coating were radial cracks (region labeled $R$ in Figure 3.5.6). In addition, no excess oxidation was observed on any of the plasma sprayed coated specimens after completion of the thermal shock testing.

The cracking observed within these plasma spray coatings after the thermal shock testing is not considered a problem because plasma sprayed piston ring coatings used in current production diesel engines exhibit similar crack patterns and these cracks are not detrimental to the friction and wear properties of these coatings.

\subsection{Additional Glassy Phase Development}

The initial pin-on-disk friction and wear testing of the cast iron porcelain enamel (CIPE) composition revealed that this composition had high friction values (above 0.3 ) and poor wear characteristics when run against either a metallic or ceramic counterface at temperature. Hard particle additions of zirconia, alumina, or chromia did not improve the wear properties of the CIPE. These hard particle additions were unsuccessful because they increased the coefficient of friction of the CIPE to above 0.4. Increasing the coefficient of friction increased the CIPE's wear rate when run against either counterface. 
These initial results illustrated that to obtain adequate wear properties, the coefficient of friction of the base CIPE composition must first be reduced to below 0.1 . Then hard particles can be added, if required, to improve the wear properties. Incorporation of solid lubricants into the base CIPE composition should reduce the coefficient of friction. Using be published friction and wear data as a guide, the following solid lubricants were selected to incorporated into the CIPE: boron nitride, calcium flouride, barium flouride, silver flakes, and cesium oxythiomolybdate.

A potassium silicate composition was also selected to be evaluated as a potential wear resistant cylinder liner coating. The potassium silicate was selected because it can also be applied using slurry spray techniques and its curing temperature is below $400 \mathrm{C}$. Typical firing temperatures for the CIPE composition are $700 \mathrm{C}$.

In general, the additional glassy phase development program consisted of first developing robotic slurry spray application techniques and a drying and firing cycle for each composition. Next, the compatibility of the solid lubricant with CIPE and potassium silicate compositions was determined. Finally, the friction and wear properties of the CIPE and potassium silicate compositions containing the solid lubricant additions were determined using the pin-on-disk friction and wear test.

Robotic slurry spray parameters were determined for the potassium silicate and CIPE compositions to cast iron substrates. Control of the coating viscosity and solids content were important for obtaining smooth, uniform, wet coatings which can be applied to cast iron substrates.

Next, attempts were made to determine a drying and firing cycle for each coating. A drying and firing cycle was developed for the CIPE, but a drying and firing cycle for the potassium silicate could not be developed. Problems encountered during the drying of the potassium silicate included crazing and blistering. Drying and firing cycles evaluated to reduce the tendency of the potasium silicate to craze or blister included slow and/or fast heating rates, long and short soaks at various temperatures, drying with and without humidity, air drying without any external heat, and slurry spraying the potassium silicate on warm (above 100C) substrates. All these cycles were unsuccesful. For this reason, it was decided to drop this coating composition from the program.

The chemical and physical stability of the solid lubricants and the CIPE was determined by mixing the CIPE with five and 10 weight percent additions of each solid lubricant and 
FIGURE 3.5 .5

CHROMIA-SILICA COATED FAIEX SPECIMENS

AFTER THERMAL SHOCK TESTING

MAC INIFICA'TION 3.5X

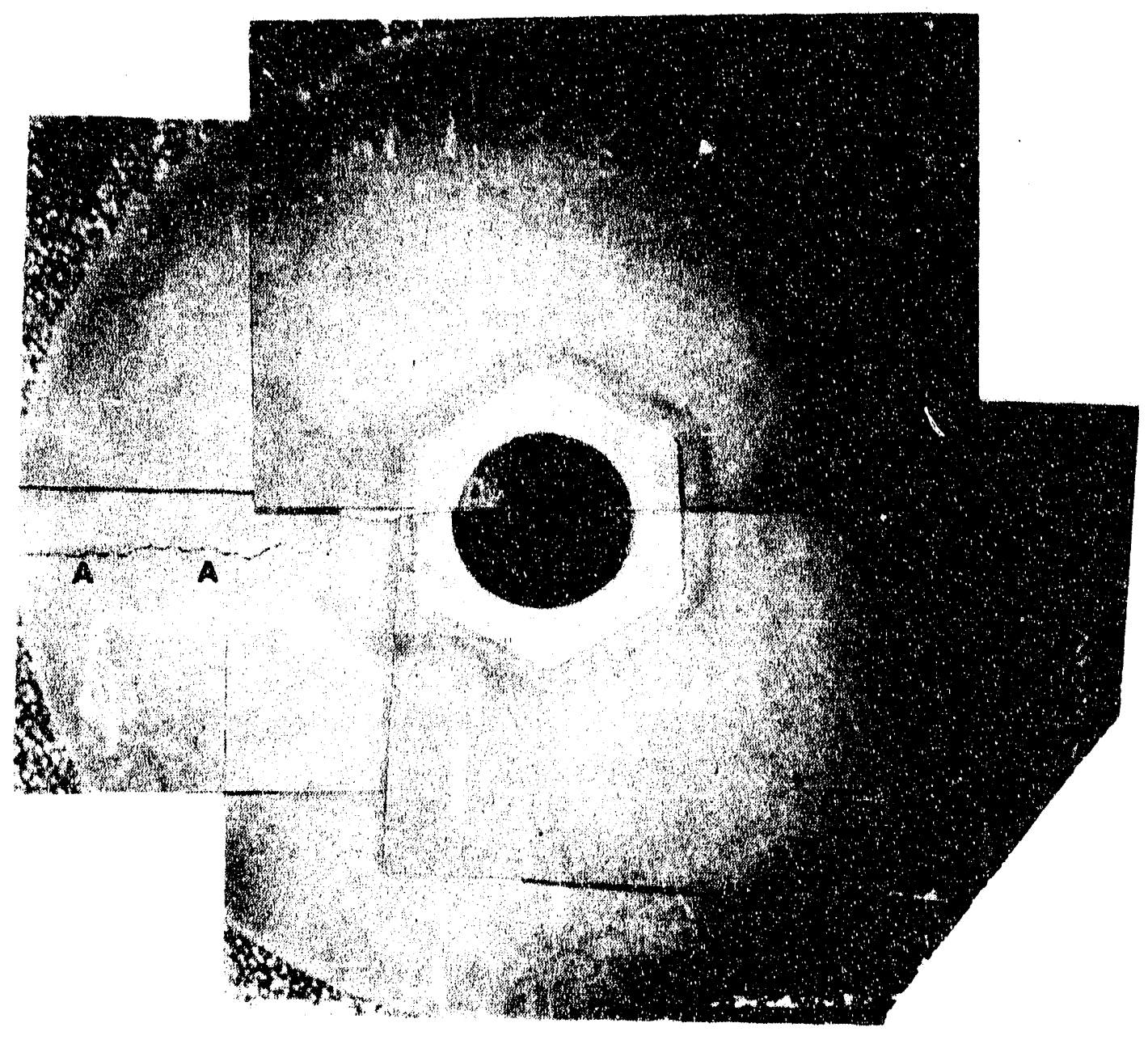


FIGURE 3.5.6

HIGH CARBON IRON-MOLYBDENUM COATED

FALEX SPECIMENS AFTER THERMAL SHOCK TESTING

\section{MAGNIFICATION 3.5X}

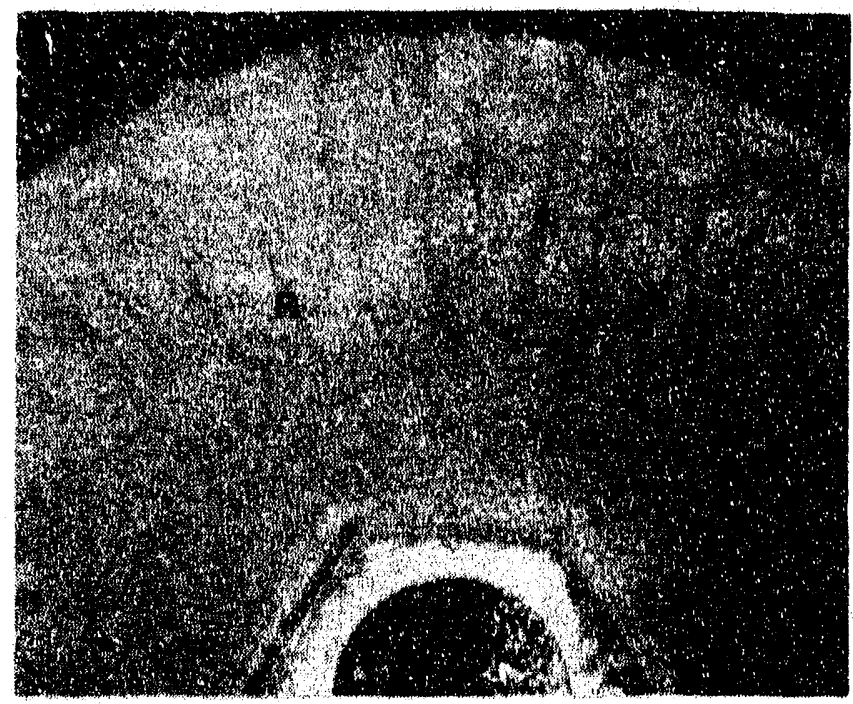

MAGNIFICATION 30X

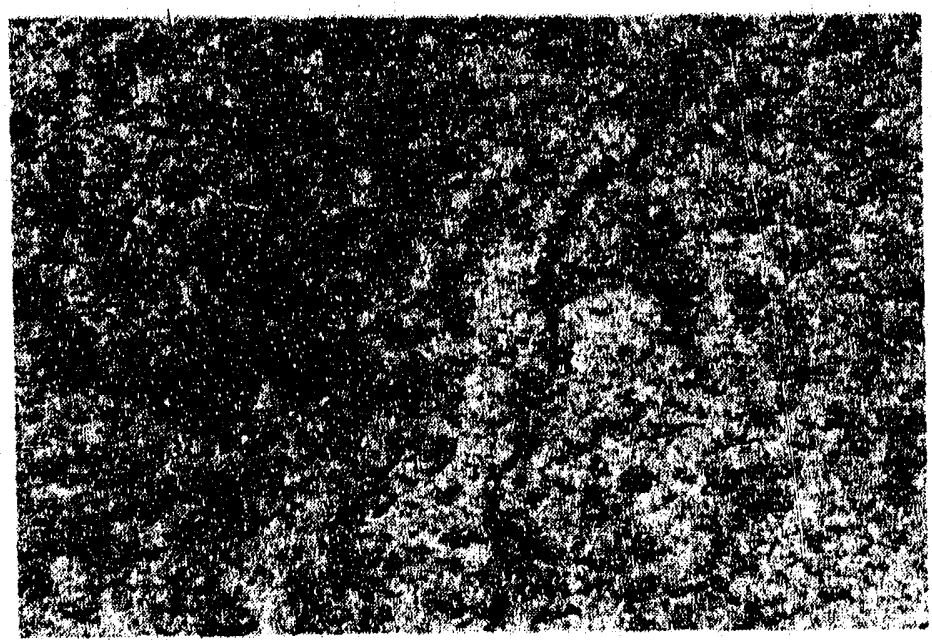


recording the physical appearence and viscosity of each CIPE, solid lubricant mixture at regular time intervals over a thirty day period (a sudden increase or decrease in viscosity and or a change in color or physical appearence would indicate a chemical reaction occuring.). No adverse chemical reactions were observed between any of the solid lubricants and the CIPE. Then combinations of one or more of the solid lubricants were blended with the CIPE and the stability of these mixtures evaluated. Again no adverse chemical reactions were observed.

Next, the CIPE compositions containing each of the solid lubricants were slurry sprayed onto cast iron substrates and fired. Chemical interactions between the CIPE and the solid lubricants during the drying and firing cycle (i.e., some of the solid lubricants acted as a flux) required that a different firing schedule be determined for each CIPE plus solid lubricant composition. Once the proper firing cycle was determined, the friction and wear properties of each composition were characterized by pin-on-disk friction and wear testing running using a ceramic counterface at $350 \mathrm{C}$, lubricated.

The addition of the 2.5 weight percent silver flake did not reduce the coefficient of friction of the CIPE. Howe ver, increasing the silver additions to 5 and 10 weight percent reduced the coefficient of friction of the CIPE from above 0.35 to .31 and .26 , respectively. Although the silver flake additions did reduce the coefficient of friction, this CIPE composition did not meet the wear goal of this program because a $2.5 \mathrm{~mm}$ wide wear scar developed on these coatings after less than 120 minutes of testing. Examination of the specimens after the friction and wear testing showed that the reduction in coefficient of friction occured because the solid lubricants were smeared across the wear track. This examination also revealed that the coating crushed and then spalled under the compressive load of the ceramic pin. Thus, the low compressive strength of this coating was the reason for the poor wear rates.

Coefficient of friction values of 0.26 were obtained with a five weight percent $\mathrm{BaF}_{2}$ addition. Reducing the friction coefficient again did not produce a coating which met the wear goals of this program because of the low compressive strength of the base enamel composition. The coating crushed and spalled under the compressive loading of the ceramic counterface during the pin-on-disk testing and a $2.5 \mathrm{~mm}$ wide wear scar developed within the enamel after only 120 minutes of testing. Increasing the $\mathrm{BaF}_{2}$ content to 10 weight percent increased the coefficient of friction to 0.36 . Again, coating, crushing and spallation occured during testing and the test was terminated after 120 minutes because a $2.5 \mathrm{~mm}$ wear scar developed. 
Brown nitride (BN) additions at either a 2.5 or 5 weight percent, did not reduce the coefficient of friction of the CIPE. These compositions developed $2.5 \mathrm{~mm}$ wear scars running against the zirconia counterface after less than 5 minutes of testing. Again the wear mechanism was first crushing and then spalling of the coating under the compressive loading of the ceramic counterface.

The cesium oxythiomolybdate solid lubricant additions produced CIPE coatings with coefficient of friction values of 0.09 at the start of the pin-on-disk testing. However, once the zirconia counterface wore through the top surface of the CIPE, the coefficient of friction rapidly increased to above 0.36 . Thus, while these compositions had acceptable wear rates at the start of the test, the wear rates increased dramatically once the zirconia counterface wore through the top surface of the coating and crushing of the coating began. On these specimens a $2.5 \mathrm{~mm}$ wide wear scar developed after only 30 minutes of pin-on-disk testing.

Combinations of the solid lubricants additions to the CIPE were evaluated next. These combinations included:

1. CIPE plus 5 percent silver flake and 2.5 percent $\mathrm{BaF}$,

2. CIPE plus 5 percent silver flake and 5 percent $\mathrm{BaF}$,

3. CIPE plus 10 percent silver flake and 2.5 percent $\mathrm{BaF}$,

4. CIPE plus 10 percent silver flake and 5 percent $\mathrm{BaF}$.

5. CIPE plus 5 percent silver flake, 5 percent $\mathrm{BaF}$, and 5 percent $\mathrm{CaF}$.

Smooth, uniform coatings with glossy physical appearances were obtained from of all these CIPE, plus solid lubricant compositions. However, the pin-on-disk friction and wear test results were disappointing. Running against a zirconia counterface, a $2.5 \mathrm{~mm}$ wide wear scar developed on each CIPE plus solid lubricant composition, irrespective of the solid lubricant type or percentage, after less than 5 minutes of testing.

Figure 3.6.1 shows the surface after testing of three regions from the same CIPE plus 5 percent silver flake and 2.5 percent BaF solid lubricant coated specimen. Very little wear is apparent on the surface contained in Figure 3.6.1A. Extensive spalling of the CIPE was observed in Figure 3.6.1C (area C). Also observed in Figure 3.6.1C, were many bubbles (area D) in the CIPE microstructure. No bubbles were observed in the region which showed very little wear (Figure 3.6.1 A). A moderate amount of spallation can be observed on the surface shown in Figure 3.6.1B. In this photomicrograph, the spallation, labeled B, initiated in areas were bubbles were on or close to the surface. Thus, the reason for the poor wear characteristics of the CIPE was the large amount of bubbles in the CIPE. The bubbles reduced the compressive strength of the CIPE, and for this reason, the CIP crushed under the load of the ceramic counterface during testing. 
FICIURE 3.6.1

CIPE SURFACES AFIER PIN.ON-IDISK TESTING

(MACNIIICAIION 25X)

\section{A. REGION WITH VERY}

LITTIS WEAR

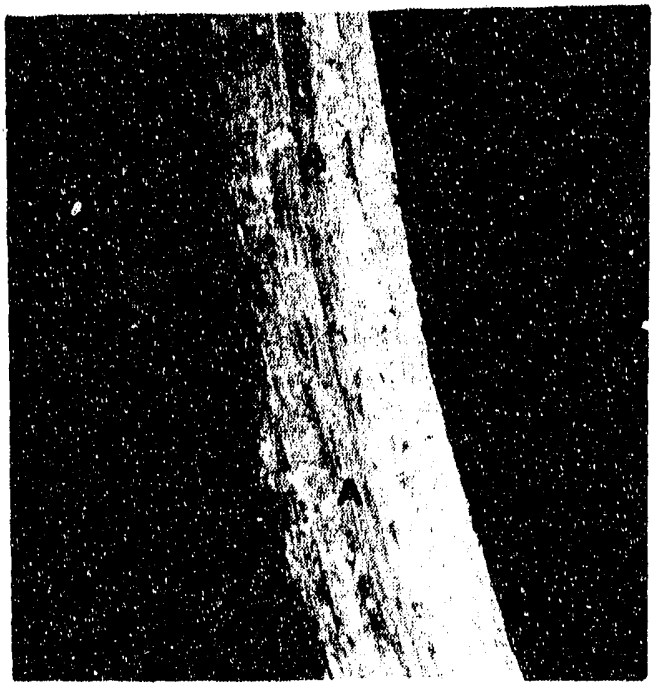

B. MODERA'TE WEAR REGION

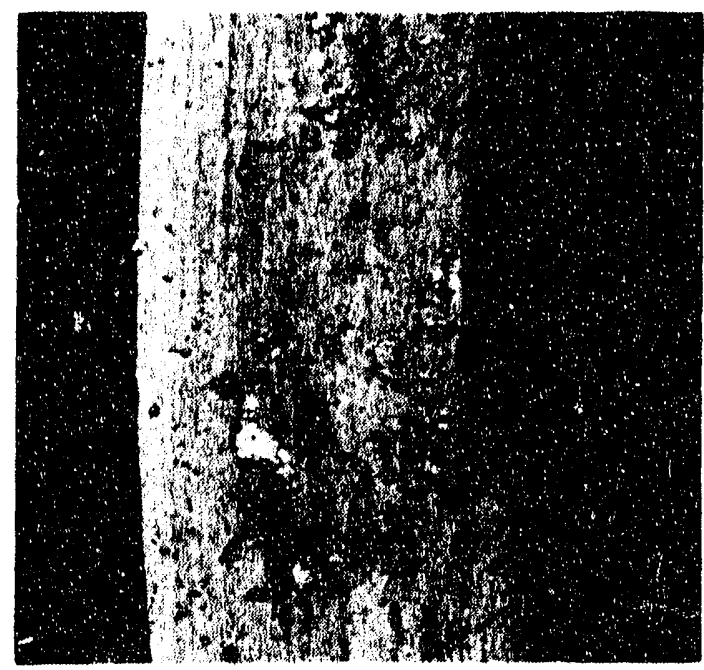

C. SEVERE WEAR REGION

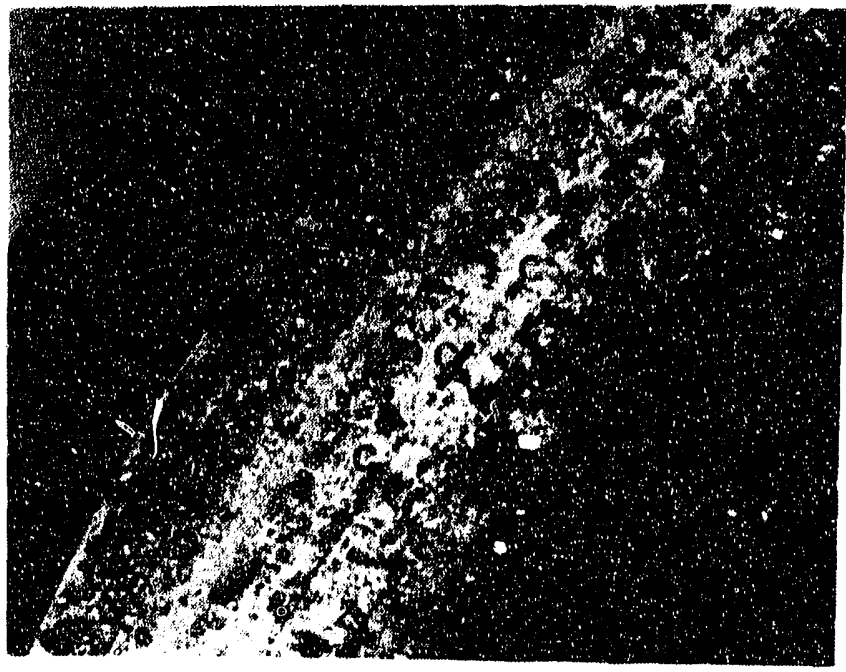



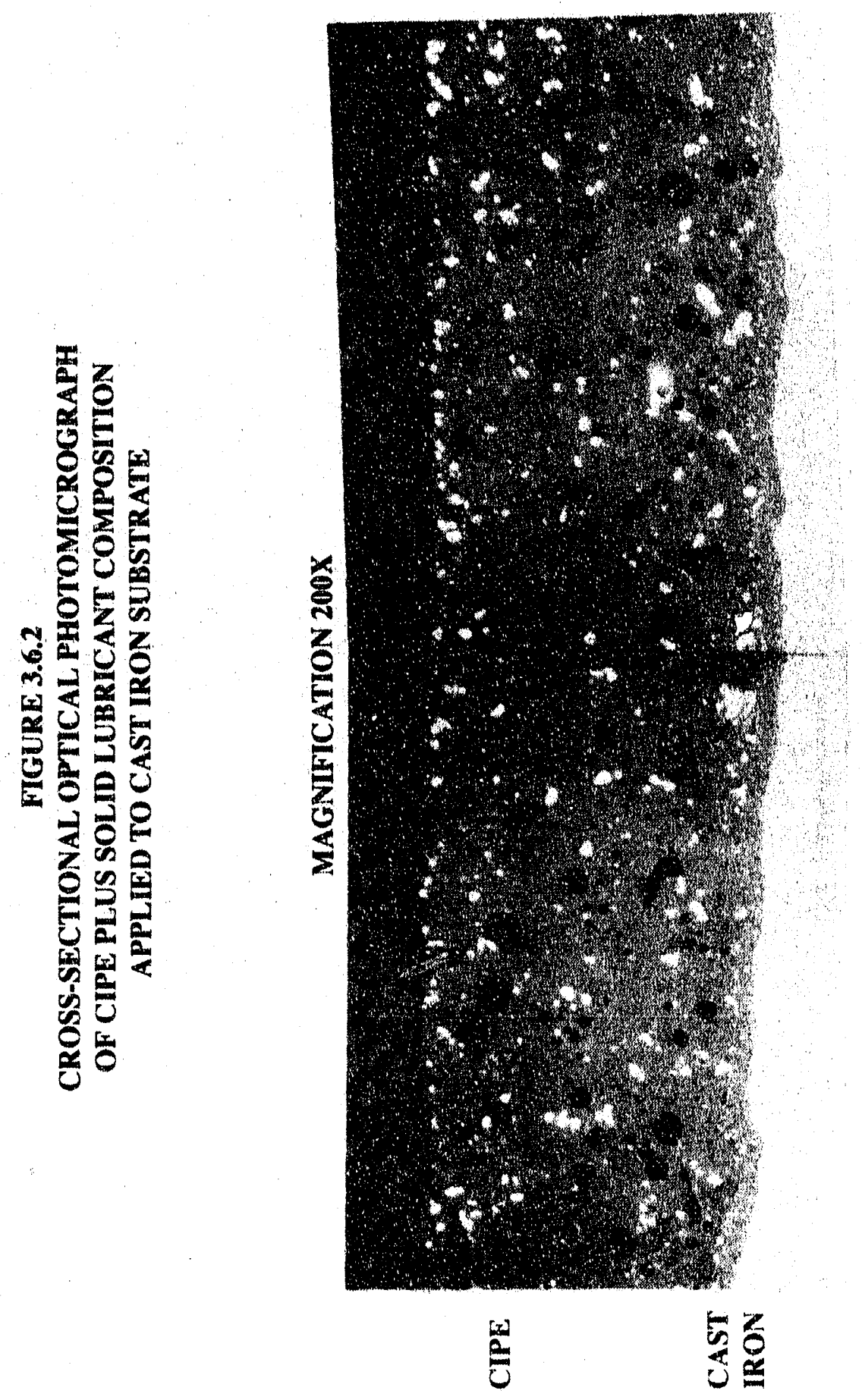
FIGURE 3.6.3

EFFECT OF HEATIVG RATE ON CIPE PLUS

SOLID LUBRICAN'T MICROSTRUCTURE

(MAGNIFICATION 200X)

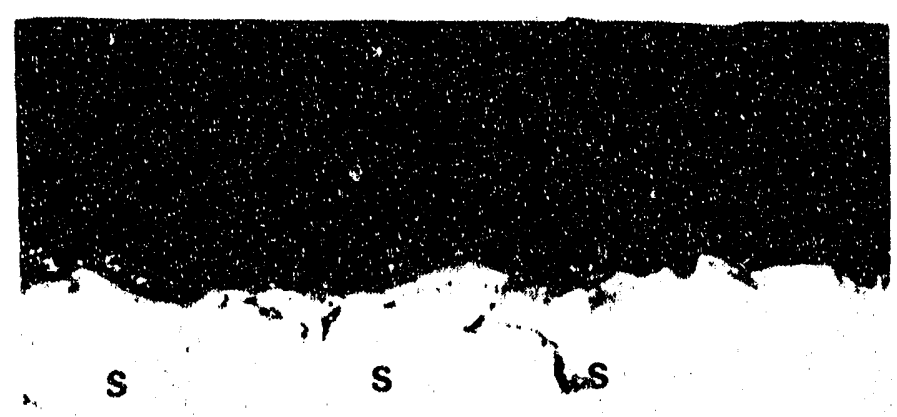

A. SLOW HEATNG RATE

B. FAST HEATING RATE
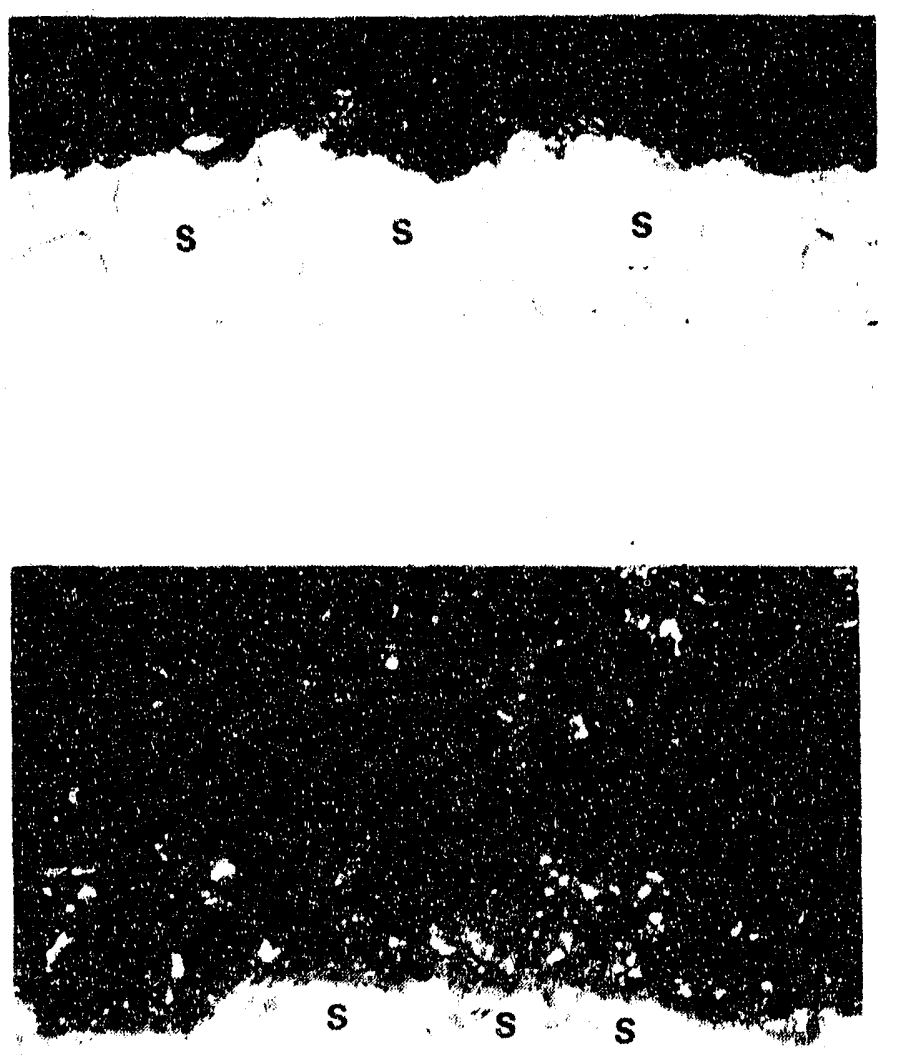

C. FAST HEATING RATE WITH LONG SOAK TIME 
A cross-sectional optical, hotomicrograph of a CIPE plus solid lubricant coating applied to a cast iron substrate is contained in Figure 3.6.2. This photomicrograph shows a large amount of bubbles in the CIPE (dark circles labeled F). The bubbles range in size and are located across the entite width of the coating. This photomicrograph also shows that the solid lubricant additions (white particles labeled $\mathrm{A}$ ) are also uniformly distributed throughout the CIPE.

After the mechanism for the poor compressive strength of the CIPE was identified, a program was initiated to determine if the number and size of the bubbles could be reduced by altering the CIPE's firing cycle. The firing cyles evaluated consisted of very fast heating rates, i.e., placing the specimen in a hot furnace, and very slow heating rates, $2 \mathrm{C} /$ minute, in addition to long and short soak times at temperature.

The results of these firing studies are illustrated in Figure 3.6.3. Using a slower heating rate, Figure 3.6.3A, reduced the size of the bubbles. However, the number of bubbles contained in the microstructure increased. Large bubbles were characteristic of the the faster heating rate. These large bubbles, Figure 3.6.3B, were concentrated at the CIPE, cast iron interface. Increasing the soak time did not eliminate the bubbles, Figure 3.6.3C. Instead, the longer soak times caused the solid lubricant particles to coalesce into larger particles located at either the top of the CIPE or at the CIPE, cast iron interface. In conclusion, none of the firing cycles evaluated resulted in a bubble-free CIPE microstructure.

\subsection{Conclusions}

Chemical or physical vapor deposition and plasma spray techniques can be used to apply wear resistant coatings to the outer diameter of piston rings. Wear resistant coatings can be applied to the inner diameter of cylinder liners using low temperature arc vapor deposition and plasma spray techniques.

Wear resistant coatings appited using chemical, physical, or low temperature arc vapor deposition techniques deposit coatings which conform to the topography of the surfaces to which they are applied. Thus, if these methods are used for applying coatings to surfaces which already have the desired surface finish, these coatings will not require any additional machining after application.

Falex pin-on-disk and Hohman A- 6 friction and wear testing identified two wear resistant coating pairs which met the friction and wear goals of this program. The coating pairs identified were: 
1. A plasma sprayed high carbon iron-molybdenum coated piston ring running against a plasma sprayed chromia-silica coated cylinder liner and,

2. A plasma sprayed high carbon iron-molybdenum coated piston ring against a low lemperature arc vapor deposited chrome nitride coated cylinder liner.

Chemical, and low temperature arc vapor deposition techniques, using current processing technology, can not apply coatings thick enough to meet the existing commercial diesel engine durability requirements. To meet the current commercial diesel engine durability requirements, coatings with thicknesses greater than 15 microns are required. For this reason, additional process development is needed to learn how to apply uniform, adherent coating using either chemical or low temperature arc vapor deposition techniques.

Coefficient of friction values obtained from wear resistant coatings in sliding applications are dependent, in part, by the surface finish of the sliding surfaces. High carbon ironmolybdenum coated rub shoes with a surface finish above 40 microinches exhibited 0.4 coefficient of friction when run against a plasma sprayed chromia-silica coated disk with a surface finish of $5-10$ microinches. These high coefficient of friction values increased the contact surface temperatures to well above $350 \mathrm{C}$. For this reason, this material pair had an average wear coefficient of $10^{-5} \mathrm{~mm}^{3} / \mathrm{N}-\mathrm{m}$. These high carbon iron-molybdenum rub shoes were reground to obtain a 5-10 microinch surface finish. The reground shoes recorded a coefficient of friction value to less than 0.1 , running against the chromia-silica coared disk. The lower coefficient of friction values reduced the average wear coefficient for this material pair to less than $10^{-8} \mathrm{~mm} / \mathrm{N}-\mathrm{m}$.

The adhesion of coatings with different chemistries, and applied using different methods (i.e., plasma spray or chemical vapor deposition) can not be evaluated using the Revetest. Instead, a modified tensile pull adherence test should be used for evaluating the adhesion of these coatings. The tensile pull adherence test showed that adherence values of above $9 \mathrm{MPa}$ are adequate for wear resistant coatings in sliding applications.

The cast iron porcelain enamel compositions evaluated in this program had good adhesion to the metallic substrates to which they were applied. However, this enamel composition running at $350 \mathrm{C}$, lubricated, against a ceramic counterface in a pin-on-disk friction and wear test had coefficient of friction values above 0.25 and very poor wear coefficients $\left(10^{-3} \mathrm{~mm}^{3} / \mathrm{N}-\mathrm{m}\right)$. Addition of hard particles to the enamel composition increased the coefficient of friction values of these compositions to above 0.3. A small decrease in coefficient of friction values was obtained, for these compositions, by the addition of silver flake or barium fluoride solid lubricants to the base enrmel composition. 
Bubbles, in the enamel microstructure, reduced the compressive strength of the enamel compositions and were the reason for the extremely poor average wear rates of all the enamel compositions.

\subsection{Recommendations For Additional Work}

The Hohman friction and wear test and the characterization studies have identified the plasma sprayed high carbon iron-molybdenum, the plasma sprayed chromia-silica as potential wear resistant piston ring coatings and the low temperature arc vapor deposited chrome nitride and plasma sprayed chromia-silica as potential wear resistant cylinder liner coatings.

All the plasma spraying in this program used an O.D. (outer diameter) plasma gun. Application of a wear resistant coating to the bore of a cylinder liner will require the use of an I.D. (inner diameter) plasma gun. Additional process optimization using the I.D. plasma spray gun is recommended. This optimization study will conclude with the plasma spraying of simulated piston rings with the high carbon iron-molybdenum and a simulated cylinder liner with the chromia-silica. The friction and wear properties of these simuiated components will be further characterized for friction and wear in a reciprocating test which will closely simulate low heat rejection diesel engine operating conditions.

The wear curves developed for the chrome nitride coating showed that a 15 micron thick coating is required to meet the commercial durability requirements of a wear resistant cylinder liner coating. It is recommended that process parameters for application of a 15 micron thick low temperature arc vapor deposited chrome nitride cuating to the bore of cylinder liners be developed. Upon completion of this process development, simulated cylinder liner components will be coated with and be evaluated for friction and wear running against a plasma sprayed high carbon iron-molybdenum coated piston rings in a reciprocating friction and wear test.

The glassy phase development showed that an enamel coating with bubble-free microstructure is required to prevent crushing of the enamel under the load during a friction and wear test. This program also showed that the coefficient of friction of an enamel surface can be reduced by the additions of solid lubricants to the enamel composition. It is recommended that the wear resistant enamel development be continued concentrating on enamel compositions which develop bubble-free microstructures. Then solid lubricant can be added, if required, to reduce the coefficient of friction of the enamel. 


\section{Appendix 1}

\section{Individual Pin-On-Disk Friction \& Wear Results}

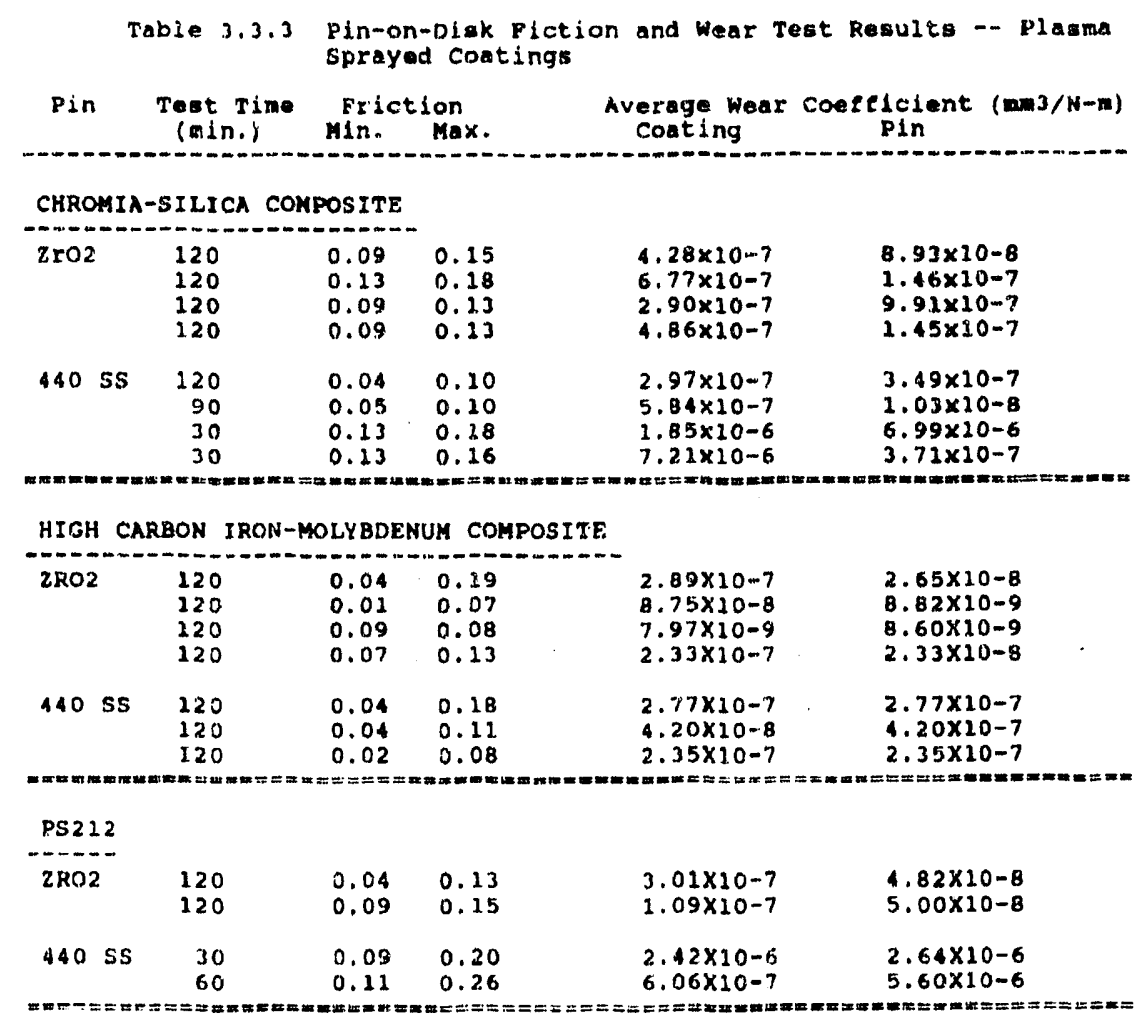

HIGH COBALT-CHROMIUM WITH TRTBALOY INTERMETALLIC MMTERXALS

\begin{tabular}{|c|c|c|c|c|c|}
\hline $2 \mathrm{rOz}$ & $\begin{array}{l}120 \\
120\end{array}$ & $\begin{array}{l}0.18 \\
0.18\end{array}$ & $\begin{array}{l}0.33 \\
0.22\end{array}$ & $\begin{array}{l}2.52 \times 10-7 \\
2.72 \times 10-6\end{array}$ & $\begin{array}{l}4.07 \times 10-7 \\
2.57 \times 10-7\end{array}$ \\
\hline $840 \mathrm{sS}$ & 220 & 0.18 & 0.33 & $2.52 \times 10-7$ & $4.07 \times 10-7$ \\
\hline
\end{tabular}

NICKEL, CHROMIUM, MOLYBDENUM BLEND

$\begin{array}{lccccc}2502 & 120 & 0.07 & 0.13 & 3.78 \times 10-8 & 1.98 \times 10.8 \\ & 120 & 0.09 & 0.13 & 3.65 \times 10-8 & 1.98 \times 10-8 \\ 440 \mathrm{sS} & 120 & 0.25 & 0.26 & 4.07 \times 10-7 & 5.46 \times 10-7 \\ & 60 & 0.20 & 0.11 & 3.52 \times 10-7 & 1.99 \times 10-6\end{array}$

Chromia-silica, high carbon iron-molybdenum, and PS 212 evaluated further because they met the program goals with respeci to friction coefficient and pin and disk wear rates.

High cobalt-chromium with tribaloy intermediate and high nickel, chromium coatings were dropped because of high coefficent friction and either pin or disk wear coefficients. 
Table 3.3.3 (Cont'd)

Pin-On-Disk Friction \& Wear Test Results

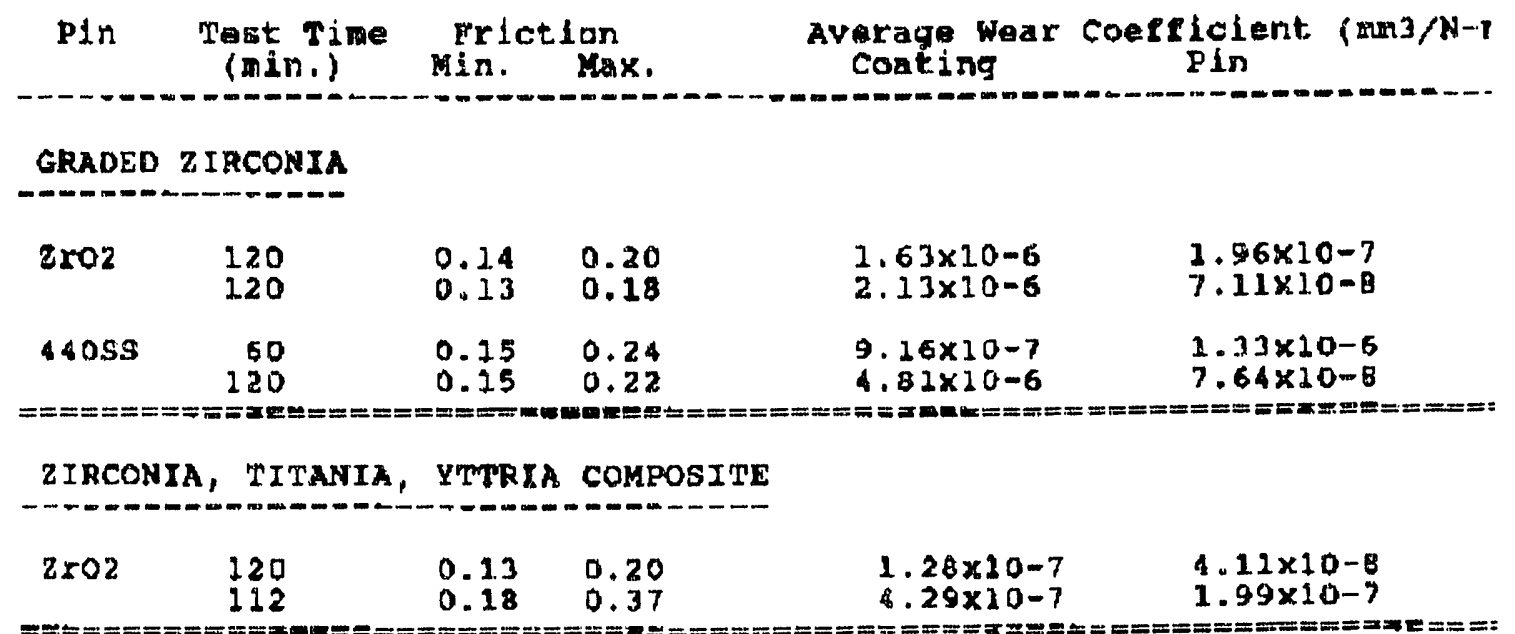

HIGH MOLYBDENUK, NICKEL, CHROMIUM BLENO

\begin{tabular}{|c|c|c|c|c|c|}
\hline 2roz & $\begin{array}{l}120 \\
120 \\
220 \\
120\end{array}$ & $\begin{array}{l}0.09 \\
0.04 \\
0.09 \\
0.09\end{array}$ & $\begin{array}{l}0.18 \\
0.22 \\
0.24 \\
0.29\end{array}$ & $\begin{array}{l}6.02 \times 10-8 \\
1.79 \times 10-8 \\
4.34 \times 10-8 \\
1.06 \times 10-8\end{array}$ & $\begin{array}{l}3.33 \times 10-7 \\
2.47 \times 10-7 \\
2.89 \times 10-7 \\
4.43 \times 10-7\end{array}$ \\
\hline $440 \quad 33$ & $\begin{array}{l}30 \\
90 \\
60\end{array}$ & $\begin{array}{l}0.09 \\
0.11 \\
0.09\end{array}$ & $\begin{array}{l}0.20 \\
0.39 \\
0.22\end{array}$ & $\begin{array}{l}2.64 \times 10-8 \\
9.29 \times 10-8 \\
3.16 \times 10-7\end{array}$ & $\begin{array}{l}1.21 \times 10-6 \\
1.12 \times 10-6 \\
1.40 \times 10-6\end{array}$ \\
\hline A 1203 & 126 & 0.09 & 0.24 & $5.61 \times 10-8$ & 3. $80 \times 10-7$ \\
\hline
\end{tabular}

NICKEL-CHROMIUM ALLOY

\begin{tabular}{|c|c|c|c|c|c|}
\hline 2502 & $\begin{array}{l}120 \\
120 \\
120 \\
120\end{array}$ & $\begin{array}{l}0.09 \\
0.09 \\
0.12 \\
0.09\end{array}$ & $\begin{array}{l}0.15 \\
0.15 \\
0.16 \\
0.1 .8\end{array}$ & $\begin{array}{l}3.60 \times 10-7 \\
9.82 \times 10-7 \\
1.66 \times 10-6 \\
3.42 \times 10-7\end{array}$ & $\begin{array}{l}6.16 \times 10-9 \\
1.19 \times 10-8 \\
1.08 \times 10-8 \\
2.52 \times 10-9\end{array}$ \\
\hline 440 SS & $\begin{array}{r}120 \\
120 \\
60\end{array}$ & $\begin{array}{l}0.11 \\
0.11 \\
0.09\end{array}$ & $\begin{array}{l}0.25 \\
0.20 \\
0.22\end{array}$ & $\begin{array}{l}2.64 \times 10-8 \\
9.29 \times 10-8 \\
3.16 \times 10-7\end{array}$ & $\begin{array}{l}1.21 \times 10-6 \\
1.12 \times 10-6 \\
1.40 \times 10-6\end{array}$ \\
\hline A1203 & 116 & 0.09 & 0.24 & $5.61 \times 10-8$ & $3.88 \times 10-7$ \\
\hline
\end{tabular}


Table 3.3.4.

Pin-On-Disk Friction \& Wear Test Results--Chemical, Physical Deposited Coatings

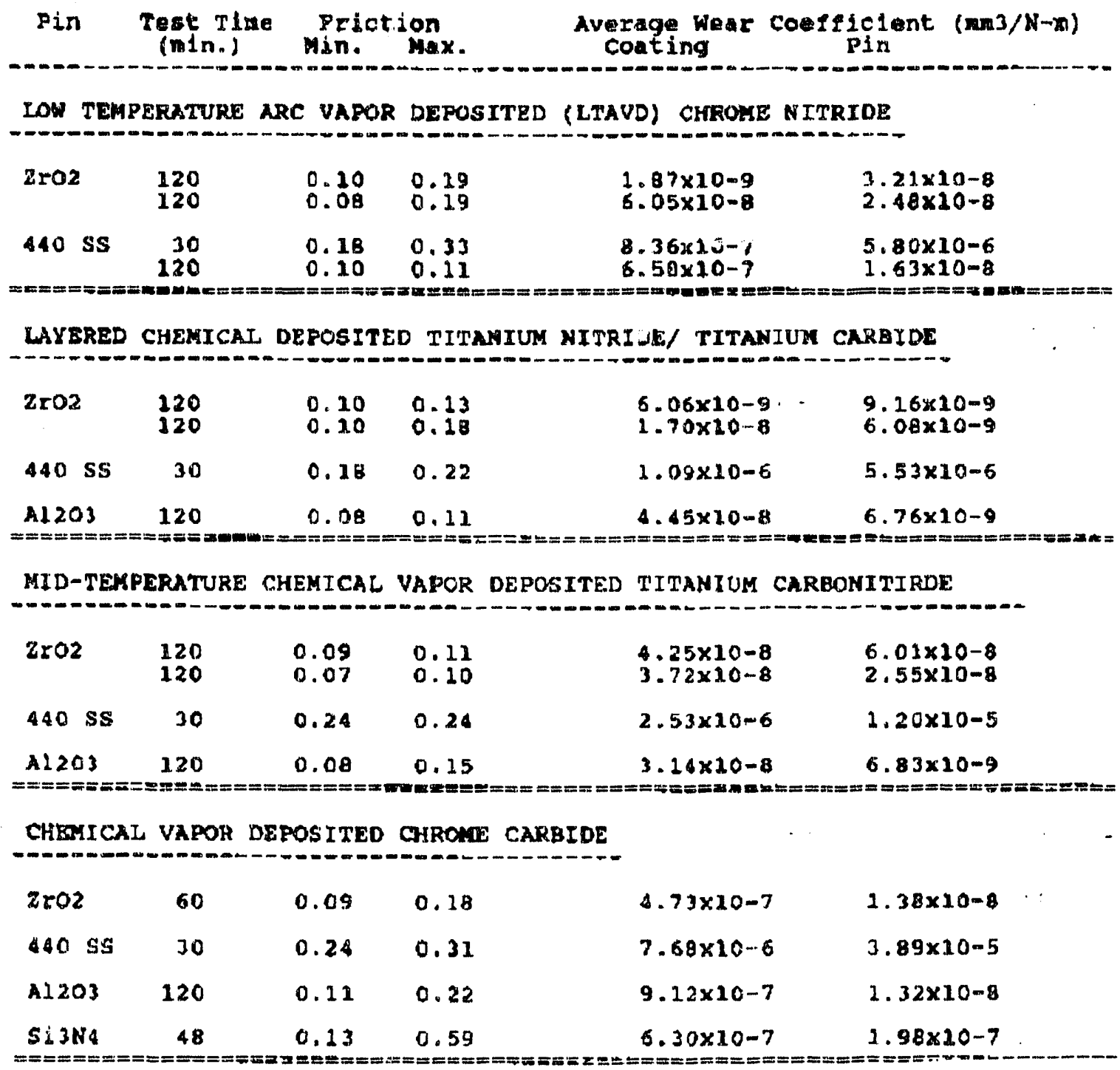


ORNL/SUb/87-SA582/1

\section{INTERNAL DISTRIBUTION}

1-2. Central Research Library

3. Document Reference Section

4-5. Laboratory Records Department

6. Laboratory Records, ORNL RC

7. ORNL Patent Section

8-10. M\&C Records Office

11. L. F. Allard, Jr.

12. L. D. Armstrong

13. P. F. Becher

14. R. F. Bernal

15. T. M. Besmann

16. P. J. Blau

17. A. Bleier

18. E. E. Bloom

19. K. W. Boling

20. R. A. Bradley

21. C. R. Brinkman

22. V. R. Bullington

23. R. S. Carlsmith

24. P. T. Carlson

25. G. M. Caton

26. S. J. Chang

27. R. H. Cooper, Jr.

28. B. L. Cox

29. D. F. Craig

30. S. A. David

31. J. H. DeVan

32. J. L. Ding

33. M. K. Ferber

34. F. M. Foust

35. W. Fulkerson

36. R. L. Graves

37. D. L. Greene

38. M. H. Harris

39. E. E. Hoffman

40. C. R. Hubbard

41. M. A. Janney
42. M. G. Jenkins

43. D. R. Johnson

44. W. F. Jones

45. D. Joslin

46. R. R. Judkins

47. M. A. Karnitz

48. M. R. Kass

49-53. B. L. P. Keyes

54. H. D. Kimrey, Jr.

55. T. G. Kollie

56. K. C. Liu

57. E. L. Long, Jr.

58. W. D. Maniy

59. R. W. McClung

60. D. J. McGuire

61. J. R. Merriman

62. D. L. Moses

63. T. A. Nolan

64. A. E. Pasto

65. J. L. Rich

66. C. R. Richmond

67. J M Robbins

68. M. L. Santella

69. A. C. Schaffhauser

70. S. Scott

71. G. M. Slaughter

72. E. J. Soderstrom

73. D. P. Stinton

74. R. W. Swindeman

75. V. J. Tennery

76. T. N. Tiegs

77. J. R. Weir, Jr.

78. B. H. West

79. F. W. Wiffen

80. S. G. Winslow

81. J. M. Wyrick

82. C. S. Yust 


\section{EXTERNAL DISTRIBUTION}

83. James $H$. Adair

University of Florida

Materials Science and

Engineering

317 MAE Bldg.

Gainesville, FL 32611-2066

84. Donald F. Adams

University of Wyoming

Mechanical Engineering Department

P. 0. Box 3295

Laramie, WY 82071

85. Jalees Ahmad

AdTech Systems Research, Inc.

1342 North Fairfield Road

Dayton, $\mathrm{OH}$ 45432-2698

86. Yoshio Akimune

NISSAN Motor Co., Ltd.

Materials Research Laboratory

1 Natsushima-Cho

Yokosuka 237

JAPAN AIR MAIL

87. Mufit Akinc

Iowa State University

322 Spedding Hall

Ames, IA 50011

88. Ilhan A. Aksay

University of Washington

Materials Science and Engineering Department, FB-10

Seattle, WA 98195

89. R. G. Alexander

BASE

26 Malvern Close

Kettering Northants NN16 AJP

UNITED KINGDOM AIR MAIL

90. Richard L. Allor

Ford Motor Company

Material Systems

Reliability Department

20000 Rotunda Drive

P.0. Box 2053, Room S-2031

Dearborn, MI 48121-2053
91. Richard T. Alpaugh

U.S. Department of Energy

Advanced Propulsion Division

CE-322, Forrestal Building

Washington, DC 20585

92. Joseph E. Amaral

Instron Corporation

Corporate Engineering Office

100 Royale Street

Canton, MA 02021

93. Edward M. Anderson

Aluminum Company of America North American Industrial

Chemicals Division

P.0. Box 300

Bauxite, AR 72011

94. Norman C. Anderson

Ceradyne, Inc.

Ceramic-to-Metal Division

3169 Redhill Avenue

Costa Mesa, CA 92626

95. Don Anson

Battelle Columbus Laboratories

Thermal Power Systems

505 King Avenue

Columbus, $\mathrm{OH}$ 43201-2693

96. Thomas Arbarias

G.B.C. Materials Corporation

580 Monastery Drive

Latrobe, PA 15650-2698

97. Frank Armatis

3M Company

3M Center

Building $60-1 N-01$

St. Paut, MN 55144-1000

98. Everett B. Arnold

Detroit Diesel Corporation

Mechanical Systems Technology

13400 Outer Drive, West

Detroit, MI 48239-4001

99. Richard M. Arons

PA Consulting Group

279 Princeton Road

Hightstown, NJ 08550 
100. Bertil Aronsson

Sandvik $A B$

S- 12680

Stockholm Lerkrogsvagen 19

SWEDEN AIR MAIL

101. Dennis Assanis

University of Illinois

Department of Mechanical

Engineering

1206 W. Green Street

Urbana, IL 61801

102. William H. Atwell

Dow Corning Corporation

3901 South Saginaw Road MS: 540

Midland, MI 48686-0995

103. V. S. Avva

North Carolina A\&T State liniversity

Department of Mechanical Engineering

Greensboro, NC 27411

104. Patrick Badgley

Adiabatics, Inc.

3385 Commerce Drive

Columbus, IN 47201

105. Sunggi Baik

Pohang Institute of Science \& Technology

Department of Materials Science and Engineering

P.0. Box 125

Pohang 790-600

KOREA AIR MAIL

106. John M. Bailey

Caterpillar, Inc.

Technical Center

Building $L$

P.0. Box 1875

Peoria, IL 61656-1875

107. Bob Baker

Ceradyne, Inc.

3169 Redhill Avenue

Costa Mesa, CA 92626
108. Frank Baker

Aluminum Company of America

Alcoa Technical Center

Alcoa Center, PA 15069

109. J. G. Baldoni

GTE Laboratories Inc.

40 Sylvan Road

Waltham, MA 02254

110. C1ifford P. Baillard

Allied-Signal, Inc.

Ceramics Program

P.0. Box 1021

Morristown, NJ 07962-1021

111. M. Balu

Amoco Performance Products Inc.

4500 McGinnis Ferry Road

Alpharetta, GA 30202

112. B. P. Bandyopadhyay

Toyohashi University of Technology

School of Production Systems Engineering

Tempaku-Cho Toyohashi 440

JAPAN AIR MAIL

113. P. M. Barnard

Ruston Gas Turbines Limited

Metallurgical Laboratory

P. 0. Box 1

Lincoln LN2 5DJ

ENGLAND AIR MAIL

114. Harold N. Barr Hittman Corporation

9190 Red Branch Road

Columbia, MD 21045

115. Renald D. Bartoe

Vesuvius McDanel

510 Ninth Avenue

Box 560

Beaver Falls, PA 15010-0560

116. Donald M. Bartos

Dow Corning Corporation

Advanced Ceramics Program

Midland, MI 48686-0995 
117. David L. Baty

Babcock \& Wilcox-LRC

P.0. Box 11165

Lynchburg, VA 24506-1165

118. Donald F. Baxter, Jr.

ASM International

Advanced Materials and

Processes

Materials Park, OH 44073-0002

119. M. Brad Beardsley

Caterpillar, Inc.

Advanced Materiais Technology

Technical Center Bldg. E

P.0. Box 1875

Peoria, IL 61656-1875

120. Robert Beck

Teledyne CAE

Materials Engineering/Programs

1330 Laskey Road

P.0. Box 6971

Toledo, $\mathrm{OH} 43612$

121. John C. Bell

Shell Research Limited

Thornton Research Centre

P.0. Box 1

Chester, Chl 3SH

ENGLAND AIR MAIL

122. Albert H. Bell, III

General Motors Technical Center 30200 Mound Road

Engineering Building/W3 Turbine Warren, MI 48090-9010

123. M. Bentele

Xamag, Inc.

259 Melville Avenue

Fairfield, CT 06430

124. Larry D. Bentsen

BF Goodrich Company

R\&D Center

9921 Brecksville Road

Brecksville, OH 44141

125. Joseph C. Bentz

ENCERATEC

2525 Sandcrest Drive

Columbus, IN 47203
126. Louis Beregszazi

Defiance Precision Products

P.0. Drawer 428

Defiance, $\mathrm{OH} 43512$

127. Tom Bernecki

Northwestern University

BIRL

1801 Maple Avenue

Evanston, It 60201-3135

128. Charles F. Bersch

Institute for Defense Analyses

1801 North Beauregard Street

Alexandria, VA 22311

129. Ram Bhatt

NASA Lewis Research Center

21000 Brookpark Road

Clevel and, $\mathrm{OH} 44135$

130. Deane I. Biehler

Caterpiliar, Inc.

Engineering and Research Materials

Technical Center, Building $E$

P.0. Box 1875

Peoria, IL 61656-1875

131. John. W. Bjerklie

Consol idated Natural Gas

Service Co., Inc.

Research Department

CNG Tower

Pittsburg̣h, PA 15222-3199

132. William D. Bjorndahl

TRW, Inc.

One Space Park

Building 01, Room 2040

Redondo Beach, CA 90278

133. Keith A. Blakely

Advanced Refractory

Technologies, Inc.

699 Hertel Avenue

Buffalo, NY 14207

134. Edward G. Bl anchard

Netzsch Inc.

119 Pickering Way

Exton, PA 19341 
135. Keith Blandford

Boride Products, Inc.

2879 Aero Park Drive

Traverse City, MI 49684

136. Bruce Boardman

Deere and Company Technical

Center

3300 River Drive

Moline, IL 61265

137. Russe11 Bockstedt

Hoechst Celanese Corporation

150 JFK Parkway

Short Hills, NJ 07078

138. M. Boehmer

DLR German Aerospace Research Establishment

Postfach 906058

D-5000 Koln 90

GERMANY AIR MAIL

139. Lawrence P. Boesch

EER Systems Corp.

1593 Spring Hill Road

Vienna, VA 22182-2239

140. Donald H. Boone

Boone \& Associates

2412 Cascade Drive

Walnut Creek, CA 94598-4313

141. Tom Booth

Allied-Signal Aerospace Company

AiResearch Los Angeles

Division

2525 West 190th Street

Torrance, CA 90509-2960

142. Tibor Bornemisza

Sundstrand Power Systems

4400 Ruffin Road

San Diego, CA 92186-5757

143. J.A.M. Boulet

University of Tennessee

Department of Engineering Science and Mechanics

310 Perkins Hall

Knoxville, TN 37996-2030
144. H. Kent Bowen

Massachusetts Institute of Technology

77 Massachusetts Avenue

Room E40-434

Cambridge, M.4 02139

145. Leslie J. Bowen

Materials Systems

53 Hillcrest-Road

Concord, MA 01742

146. Steven C. Boyce

Air Force Office of

Scientific Research

AFOSR/NA B1dg. 410

Bolling AFB DC 20332-6448

147. Gary L. Boyd

CEC

400 Howe 11 Avenue, No. 4

Warland, WY 8240I

148. Steve Bradley

UOP Research Center

50 East Algonquin Road

Des Plaines, IL 60017-6187

149. Michael C. Brands

Cummins Engine Company, Inc.

P.0. Box 3005

Mail Code 50179

Columbus, IN 47201

150. Raymond J. Bratton

Westinghouse Science and

Technology Center

1310 Beulah Road

Pittsburgh, PA 15235

151. John J. Brennan

United Technologies Corporation

Research Center

Silver Lane, MS: 24

East Hartford, CT 06108

152. Jeff D. Bright

Ceramatec, Inc.

2425 South 900 West

Salt Lake City, UT 84108 
153. Terrence K. Brog

Coors Ceramics Company

Corporate Development and Technology

4545 McIntyre Street

Golden, CO 80403

154. Gunnar Broman

317 Fairlane Drive

Spartanburg, SC 29302

155. A1 Brown

High-Tech Materials Alert

P.0. Box 882

Dayton, NJ 08810

156. Jesse Brown

Virginia Polytechnic Institute and State University

Center for Advanced Ceramic Materials

B1 acksburg, VA 24061-0256

157. Sherman D. Brown University of Illinois

Materials Science and

Engineering Department

105 South Goodwin Avenue

204 Ceramics Building

Urbana, IL 61801

158. S. L. Bruner

Ceramatec, Inc.

2425 South 900 West

Salt Lake City, UT 84119

159. Adolfo Brusaferro

Keramont Corporation

4231 South Fremont Avenue

Tucson, AZ 85714

160. W. Bryzik

U.S. Army Tank Automotive Command

R\&D Center

Propulsion Systems Division Warren, MI 48397-5000

161. S. T. Buljan

GTE Laboratories, Inc.

40 Syivan Road

Waltham, MA 02254
162. S. J. Burden

GTE Valenite

1711 Thunderbird

Troy, MI 48084

163. Curt V. Burkland

AMERCOM, InC.

8928 Fullbright Avenue

Chatsworth, CA 91311

$$
\therefore
$$

164. Bill Bustamante

AMERCOM, Inc.

8928 Fullbright Street

Chatswirth, CA 91311

165. Oral Buyukozturk

Massachusetts Institute of Technology

77 Massachusetts Avenue

Room 1-280

Cambridge, MA 02139

166. David A. Caillet

Ethyl Corporation

451 Florida Street

Baton Rouge, LA 70801

167. Frederick J. Calnan

Heany Industries, Inc.

249 Briarwood Lane

P.0. Box 38

Scottsville, NY 14546

168. Roger Cannon

Rutgers University

Ceramics Department

P.0. Box 909

Piscataway, NJ 08855-0909

169. Scott Cannon

P.0. Box 567254

Atlanta, GA 30356

170. Harry W. Carpenter

19945 Acre Street

Northridge, CA 91324

171. David Carruthers

Kyocera Industrial Ceramics Company

P.0. Box 2279

Vancouver, WA 98668-2279 
172. Calvin H. Carter, Jr. Cree Research, Inc. 2810 Meridian Parkway Durham, NC 27713

173. J. David Casey 35 Atlantis Street West Roxbury, MA 02132

174. Jere G. Castor

J. C. Enterprise 5078 North 83rd Street Scottsdale, AZ 85250

175. James D. Cawley

Case Western Reserve University Materials Science and Engineering Department Cleveland, $\mathrm{OH} 44106$

176. Thomas C. Chadwick Den-Mat Corporation P.0. Box 1729

Santa Maria, CA 93456

177. Ronald H. Chand

Chand Kare Technical Ceramics 2 Coppage Drive Worcester, MA 01603

178. Robert E. Chaney

EG\&G Idaho, Inc.

Idaho National Engineering Laboratory

P.0. Box 1625

Idaho Falls, ID 83415-3525

179. Frank C. Chang

U.S. Army Materials Technology Laboratory

AMTL - EMM

405 Arsenal Street

Watertown, MA 02172

180. Robert M. Chapman

Allied-Signal Aerospace

Company

1530 Wilson Boulevard, 10th Floor

Arlington, VA 22209
181. William Chapman

Williams International Corporation 2280 West Maple Road

Walled Lake, MI 48390-0200

182. Charlie Chen

LECO Corporation

P.0. Box 211688

Augusta, GA 30917

183. Albert $A$. Chesnes

U.S. Department of Energy Transportation Technologies CE-30, Forrestal Building, 6B-094

Washington, DC 20585

184. Kaiyin Chia

Carborundum Company

P.O. Box 832

Niagara Falls, NY 14302

185. Frank Childs

EG\&G Idaho, Inc.

Idaho National Engineering Laboratory

P.0. Box 1625

Idaho Falls, ID 83415-3527

186. William J. Chmura

Torrington Company

59 Field Street

Torrington, CT 06790-4942

187. Tsu-Wei Chou

University of Delaware

Center for Composite

Materials

201 Spencer Laboratory

Newark, DE 19716

188. R. J. Christopher

Ricardo Consulting Engineers Bridge Works

Shoreham-By-Sea West Sussex BN43 5FG

ENGLAND AIR MAIL

189. Joel P. Clark

Massachusetts Institute of Technology

Room 8-409

Cambridge, MA 02139 
190. Giorgio Clarotti

Commission of the European Communities

DGXII-C3, M075, 1-53;

200 Rue de la Loi

B-1049 Brusse7s

BELGIUM AIR MAIL

191. W. J. Clegg

ICI Advanced Materials

P.0. Box 11

The Heath, Runcorn Cheshire

WA7 4QE

ENGLAND

AIR MAIL

192. Joseph Cleveland

GTE Products Corporation

Hawes Street

Towanda, PA 18848-0504

193. Gloria M. Collins

ASTM

1916 Race Street

Philadelphia, PA 19103

194. William C. Connors

Sundstrand Aviation Operations

Materials Science and

Engineering Department

4747 Harrison Avenue

P.0. Box 7002

Rockford, IL 61125-7002

195. John A. Coppola

Carborundum Company

P.0. Box 156

Niagara Falls, NY 14302

196. Normand D. Corbin

Norton Company

Advanced Ceramics

Goddard Road

Northboro, MA 01532-1545

197. Douglas Corey

Allied-Signal Aerospace Company

2525 West 190th Street

MS : T52

Torrance, CA 90504-6099
198. Keith P. Costello

Chand/Kare Technical Ceramics

2 Coppage Drive

Worcester, MA 01603-1252

199. Ed L. Courtright

Pacific Northwest

Laboratory

MS:K3-59

Richland, WA 99352

200. Anna Cox

Mitchel1 Market Reports

P.0. Box 23

Monmouth Gwent NP5 4YG

UNITED KINGDOM AIR MAIL

201. Thomas Coyle

Unocal Corporation

Unocal Science \& Technology

Division

376 South Valencia Avenue

Brea, CA 92621

202. Art Cozens

Instron Corporation

3414 Snowden Avenue

Long Beach, CA 90808

203. Robert C. Craft

American Ceramic

Society, Inc.

757 Brooksedge Plaza Drive

Westerville, $\mathrm{OH} 43081$

204. Mark Crawford

New Technology Week

4604 Monterey Drive

Annandale, VA 22003

205. Richard A. Cree

Markets \& Products, Inc.

P.0. Box 14328

Columbus, $\mathrm{OH}$ 43214-0328

206. Les Crittenden

Vesuvius McDanel

Box 560

Beaver Falls, PA 15010 
207. William J. Croft

U.S. Army Materials Technology Laboratory

405 Arsenal Street

Watertown, MA 02172

208. M. J. Cronin

Mechanical Technology, Inc.

968 Albany-Shaker Road

Latham, NY 12110

209. Gary M. Crosbie

Ford Motor Company

1430 Culver Avenue

S-2079, SRL Building

Dearborn, MI 48121-4036

210. Floyd W. Crouse, Jr.

U.S. Department of Energy

Morgantown Energy Technology Center

Collins Ferry Road

P.0. Box 880

Morgantown, WV 26505

211. John Cuccio

Allied-Signal Aerospace Company

Garrett Auxiliary Power

Division

P.0. Box 5227, MS: $1302-2 Q$

Phoenix, AZ 85010

212. Raymond Cutler

Ceramatec, Inc.

2425 South 900 West

Salt Lake City, UT 84119

213. Charles D'Angelo

GTE Laboratories, Inc.

40 Sylvan Road

Hal tham, MA 02154

214. Stephen C. Danforth

Rutgers University

Ceramic Engineering Department

P.0. Box 909

Piscataway, NJ 08855-0909
215. Sankar Das Gupta

Electrofuel Manufacturing Co., Ltd.

9 Hanna Avenue

Toronto Ontario MGK - 1 W8

CANADA AIR MAIL

216. Charles Davis

Sverdrup Technology, Inc., MSFC

620 Discovery Drive

Huntsville, AL 35806

217. Frank Davis

Allied Signal Aerospace Co. 7550 Lucerne $\mathrm{Dr}$., \# 2.03

Middleburg Heights, OH 44130

218. Robert F. Davis

North Carolina State University

Materials Engineering Department

229 Riddick Laboratory

P.0. Box 7907

Raleigh, NC 27695

219. Thomas DeAngel is

Carborundum Company

Niagara Falls R\&D Center

P.0. Box 832

Niagara Falls, NY 14302

220. George DeBell

Ford Motor Company

Material Systems Reliability Department

20000 Rotunda Drive

P.0. Bax 2053, Room S-2023

Dearborn, MI 48121-2053

22: Michael Deluca

AMP-AKZO

West Lane

Aquebogue, NY 11931

222. Gerald L. DePoorter

Colorado School of Mines

Metallurgical and Materials

Engineering Department

Golden, CO 80401 
223. J. F. DeRidder

Omni Electro Motive, Inc.,

12 Seely Hill Road

Newfield, NY 14867

224. Nick C. Dellow

Materials Technology

Publications

40 Sotheron Road

Watford Herts WDI 2QA

UNITED KINGDOM AIR MAIL

225. L. R. Dharani

University of Missouri-Rolla

224 M.E.

Rolla, MO 65401

226. Douglas A. Dickerson

Union Carbide Specialty

Powders

1555 Main Street

Indianapolis, IN 46224

227. John Dodsworth

Vesuvius Research \& Development

Technical Ceramics Group

Box 560

Beaver Falls, PA 15010

228. B. Dogan

Institut fur Werkstofforschung

GKSS-Forschungszentrum

Geesthacht GmbH

Max-Planck-Strasse

D-2054 Geesthacht

GERMANY AIR MAIL

229. Jean-Marie Drapier

FN Moteurs S.A.

Material and Processing

B-4041 Milmort (Herstai)

BELGIUM AIR MAIL

230. Kenneth C. Dreitlein

United Technologies

Research Center

Silver Lane

East Hartford, CT 06108
231. Robin A.L. Drew

Mrisill University

Department of Mining and

Setallurgical Engineering

3450 University Street

Montreal Quebec H3A 2A7

CANADA AIR MAIL

232. Winston H. Duckworth

$\mathrm{BCL}$

Columbus Division

505 King Avenue

Columbus, $\mathrm{OH} 43201-2693$

233. Edmund M. Dunn

Texel Company

6 Third Street

Lexington, MA 02173

234. Bill Durako

Sundstrand Aviation Operations

Department 789-6

4747 Harrison Avenue

P.0. Box 7002

Rockford, IL 61125-7002

235. Ernest J. Duwell

$212 \mathrm{E} 1 \mathrm{~m}$ Street

Hudson, WI 54016

236. Chuck J. Dziedzic

Coors Ceramics Company

Structural Products Group

17750 West 32nd Avenue

Golden, CO 80401

237. Robert J. Eagan

Sandia National Laboratories

Engineered Materials \& Processes Center

Org 1700

P.O. Box 5800

Aibuquerque, NM 87185-5800

238. Jeffrey Eagleson

Lanxide Corporation

Itol Connecticut Avenue, N.W.

Washington, DC 20036 
239. Harry E. Eaton

United Technologies Corporation

Research Center

Silver Lane

East Hartford, $\mathrm{Cr} 06108$

240. Harvill C. Eaton

Louisiana State University

Office of Research and Economic Development

240 Thomas Boyd Hall

Baton Rouge, LA 70803

241. Christopher A. Ebel

Carborundum Company

Technology Division

P.0. Box 337

Niagara Falls, NY 14302

242. J. J. Eberhardt

U.S. Department of Energy

Office of Transportation Materials

CE-34, Forrestal Building

Washington, DC 20585

243. Jim Edler

Eaton Corporation

26201 Northwestern

Highway

P.0. Box 766

Southfield, MI 48037

244. William A. Ellingson

Argonne National Laboratory

Materials Science \& Technology Division

9700 South Cass Avenue

Argonne, IL 60439

245. William S. Ellis

Machined Ceramics

629 N. Graham St.

N. Industrial Park

Bowling Green, KY 42101

246. Glen B. Engle

Nuclear \& Aerospace Materials Corporation

16716 Martincoit Road

Poway. CA 92064
247. Jeff Epstein

Ceramic Technologies, Inc.

2107 Jamara Lane

Houston, TX 77077

248. Kenneth A. Epstein

Dow Chemical U.S.A.

Ceramics and Advanced

Materials

800 Building

Midland, MI 48667

249. Art Erdemir

Argonne National Laboratory

Materials and Components

Technology Division

9700 South Cass Avenue

Argonne, IL 60439

250. E. M. Erwin

Lubrizol Corporation

1819 East 225th Street

Euclid, $\mathrm{OH} 44117$

251. Kenji Esaki

Toyota Technical Center U.S.A., Inc.

2000 Town Center, Suite 500

Southfield, MI 48075

252. Jose L. Escalante

Anglo-Mex-Tech. Inc.

3923 N.W. 24th Street

Miami, FL 33142

253. John N. Eustis

U.S. Department of Energy

Industrial Energy Efficiency Division

CE-221, Forrestal Building

Washington, DC 20585

254. Robert C. Evans

NASA Lewis Research Center

Terrestrial Propulsion Office

21000 Brookpark Road, MS:86-6

Cleveland, $\mathrm{OH} 44135$

255. W. L. Everitt

Kyocera International, Inc.

8611 Balboa Avenue

San Diego, CA 92123 
256. Gordon Q. Evison 332 South Michigan Avenue Suite 1730

Chicago, IL 60604

257. John W. Fairbanks U.S. Department of Energy Advanced Propulsion Division CE-322, Forrestal Building Washington, DC 20585

258. Tim Fawcett

Dow Chemical Company Central Research, Advanced Ceramics Laboratory 1776 Building Midland, MI 48674

259. Robert W. Fawley Sundstrand Power Systems Division of Sundstrand Corporation 4400 Ruffin Road P.0. Box 85757 San Diego, CA 92186-575T

260. John J. Fedorchak GTE Products Corporation Hawes Street Towanda, PA 18848-0504

261. Jeff T. Fenton Vista Chemical Company 900 Threadneedie Houston, TX 77079

262. Larry Ferrell Babcock \& Wilcox Old Forest Road Lynchburg, VA 24505

263. Raymond R. Fessler BIRL Industrial Research Lab 1801 Maple Avenue Evanston, IL 60201

264. Michelle Finch

E. 1. DuPont de Nemours \& Company, Inc.

Experimental Station

Information Center E302/301

Wilmington, DE 19898
265. Arthur D. Fine

United Technologies Corporation

Pratt \& Whitney Aircraft

400 Main Street

MS: $163-10$

East Hartford, CT 06108

266. Ross F. Firestone

Ross Firestone Company

188 Mary Street

Winnetika, IL 60093-1520

267. Sharon L. Fletcher

Arthur D. Little, Inc.

15 Acorn Park

Cambridge, MA 02140-2390

268. Thomas F. Foltz

Textron Specialty Materials

2 Industrial Avenue

Lowe 11, MA 01851

269. Renee G. Ford

Materials and Processing Report

P.0. Box 72

Harrison, NY 10528

270. John Formica

Supermaterials

2020 Lakeside Avenue

Cleveland, $\mathrm{OH} 44114$

271. Jennifer M. Fox

Dyson Refractories Limited

R\&D Laboratory

Owler Bar

Sheffield 517 38J

UNITED KINGDOM

AIR MAIL

272. Edwin Frame

Southwest Research Institute

Division 2

P.0. Drawer 28510

San Antonio, TX 78284

273. Armanet Francois

French Scientific Mission 4101 Reservoir Road, N.W. Washington DC 20007-2176

274. R. G. Frank

Technology Assessment Group 10793 Bentley Pass Lane Love? and, OH 45140 
275. David J. Franus

Forecast International

22 Commerce Road

Newtown, CT 06470

276. Marc R. Freedman

NASA Lewis Research Center

21000 Brookpark Road

MS: 49-3

Clevel and, $\mathrm{OH} 44135$

277. Douglas Freitag

LTV Missiles Division

P.0. Box 650003

MS :WT-21

Dallas, TX 75265

278. Brian R.T. Frost Argonne National Laboratory

9700 South Cass Avenue

Building 900

Argonne, IL 60439

279. Lawrence R. Frost

Instron Corporation

100 Royall Street

Canton, MA 02021

280. George A. Fryburg

Norton/TRW Ceramics

7A-4 Raymond Avenue

Salem, NH 03079

281. Xiren Fu

Shanghai Institute of Ceramics

Chinese Academy of Sciences

1295 Ding- $x i$ Road

Shanghai 200050

CHINA AIR MAIL

282. John Gahimer

P.0. Box 1302

Dublin, $\mathrm{OH} 43017$

283. J. P. Gallagher

University of Dayton Research Institute

300 College Park, JPC-250

Dayton, $\mathrm{OH}$ 45469-0120
284. Tom Garritano

University of Tennessee

Science Alliance

101 South College

Knoxville, TN 37996-1328

285. Joy A. Garwood

Norton Company

Advanced Ceramics

Goddard Road

Northboro, MA 01532-1545

286. H. Maury Gatewood

Reynolds Metals Company Corporate R\&D

Fourth and Canal Streets

P.0. Box 27003

Richmond, VA 23261

287. L. J. Gauckler

ETH-Zurich

Sonneggstrasse 5

CH-8092 Zurich 8092

SWITZERLAND

AIR MAIL

288. Peter A. Gaydos

Battelle Columbus Laboratories

505 King Avenue

Columbus, $\mathrm{OH} 43201$

289. George E. Gazza

U.S. Army Materials Technology Laboratory

Ceramics Research Division

405 Arsenal Street.

Watertown, MA 02172-0C:1

290. D. Gerster

CEA-DCOM

33 Rue De La Federation

Paris 75015

FRANCE AIR MAIL

291. John Ghinazzi

Coors Technical Cerainics Company

1100 Commerce Park Drive

Oak Ridge, TN 37830 
292. Robert Giddings

General Electric Company

Research Laboratory

P.0. Box 8

Schunectady, NY 12301

292. A. M. GTaeser

University of California

Materials Science and Mineral Engineering

Lawrence Berkeley Laboratory

Hearst Mining Building

Berkeley, CA 94720

294. Paul Glance

Concept Analysis

R\&D

950 Stephenson Highway

Dupont Automotive Development Building

Troy, MI 48007-7013

295. Joseph W. Glatz

Naval Air Propulsion Center

Systems Engineering Division

P.0. Box 7176, PE24

Trenton, NJ 08628

296. H. M. Goldberger

Superior Graphite Company R\&D

2175 East Broad Street

Columbus, $\mathrm{OH} 43209$

297. Allan E. Goldman

U.S. Graphite, Inc.

907 West Outer Drive

Oak Ridge, TN 37830

298. Stephen T. Gonczy

Allied Signal Research

P.0. Box 5016

Des Plaines, IL 60017

299. Jeffrey M. Gonzales

GTE Products Corporation

Hawes Street

Towanda, PA 18848-0504

300. Robert J. Gottschall

U.S. Department of Energy

ER-131, MS:G-236

Washington, DC 20545
301. Ear1 Graham

Cleveland State University

Department of Chemical Engineering

Eucl id Avenue at East 24th Street

Cleveland, $\mathrm{OH} 44115$

302. William A. Graham Lanxide Corporation

P.0. Box 6077

Newark, DE 19714-6077

303. Robert E. Green, Jr. Johns Hopkins University

Materials Science and Engineering Department

Baltimore, MD 21218

304. Lance Groseclose

General Motors Corporation

Allison Gas Turbine Division

P.0. Box 420, MS:W-5

Indianapolis, IN 46206

305. Mark F. Gruninger

Union Carbide Corporation

Specialty Powder Business

1555 Main Street

Indianapolis, IN 46224

306. Ernst Guge1

Cremer Forschungsinstitut GmbH\&CO.KG

Deslauer Strasse 35

D-8633 Roedental 8633

GERMANY AIR MAIL

507. Donald L. Guile

Corning Glass Works

SP-DV-1-9

Corning, NY 14831

308. Bimleshwar P. Gupta

Solar Energ./ Research Institute

Mechanical and Industrial Technology Division

1617 Cole Boulevard

Golden, CO 80401 
309. John P. Gyekenyesi

NASA Lewis Research Center 21000 Brookpark Road, MS:6-1 Clevel and, $\mathrm{OH} 44135$

310. Nabil S. Hakim

Detroit Diesel Corporation 13400 West Outer Drive Detroit, MI 48239

311. Philip J. Haley General Motors Corporation Vehicular Engineering P.0. Box 420, MS:T12A Indianapolis, IN 46236

312. Judith Hall

Fiber Materials, Inc.

Biddeford Industrial Park

5 Morin Street

Biddeford, ME 04005

313. Y. Harada

IIT Research Institute Nometallic Materials and Composites

10 West 35th Street

Chicago, IL 60616

314. R. A. Harmon

25 Schalren Drive

Latham, NY 12110

315. Amy Harmon-Barrett

Martin Marietta Laboratories

1450 South Rolling Road

Baltimore, MD 21227

316. Norman H. Harris

Hughes Aircraft Company

P.0. Box 800520

Saugus, CA 91380-0520

317. Alan Hart

Dow Chemical Company

Advanced Ceramics Laboratory

1776 Building

Midland, MI 48674
318. Pat E. Hart

Battelle Pacific Northwest Laboratories

Ceramics and Polymers

Development Section

P.0. Box 999

Richland, WA 99352

319. Stephen D. Hartline

Norton Company

Advanced Ceramics

Goddard Road

Northboro, MA 01532-1545

320. Michael H. Haselkorn

Caterpillar, Inc.

Engineering Research Materials

Technical Center, Building E

P.0. Box 1875

Peoria, IL 61656-1875

321. N. B. Havewala

Corning, Inc.

SP-PR-11

Corning, NY 14831

322. John Haygarth

Teledyne WAA Chang Albany

P.0. Box 460

Albany, OR 97321

323. Norman L. Hecht

University of Dayton Research Institute

300 College Park

Dayton, OH 45469-0172

324. Peter W. Heitman

General Motors Corporation

Allison Gas Turbine Division

P.0. Box 420, MS:W-j

Indianapolis, IN 46206-0420

325. Robert W. Hendricks

Virginia Polytechnic Institute and State University

Materials Engineering Department

210 Holden Hall

B1 acksburg, VA 24061-0237 
326. Wynne Henley Hertel Cutting Technologies, Inc. 1000 Clearview Court

Oak Ridge, TN 37830

327. Thomas L. Henson GTE Products Corporation Chemical \& Metallurgical Division Hawes Street Towanda, PA 18848

328. Thomas P. Herbel1 NASA Lewis Research Center 21000 Brookpark Road MS: 49-3 Cleveland, $\mathrm{OH} 44135$

329. Marlene Heroux Rolls-Royce, Inc. 2849 Paces Ferry Road Suite $\mathbf{4 5 0}$

At 1 anta, GA 30339-3769

330. Robert L. Hershey Science Management Corporation 1255 New Hampshire Ave., N.W. Suite 1033

Washington, DC 20036

331. Hendrik Heystek Bureau of Mines Tuscaloosa Research Center P.0. Box $L$ University, AL 35486

332. Wallace C. Higgins

Norwal Unlimited P.0. Box 1258

Alfred, NY 14802

333. Robert V. Hillery GE Aircraft Engines One Neumann Way, M.D. H85 Cincinnati, $\mathrm{OH} 45215$

334. Arthur Hindman Instron Corporation 100 Royall Street Canton, MA 02021
335. Jon Hines

American Ceramic Society, Inc. 757 Brooksedge Plaza Drive Westerville, $\mathrm{OH}$ 43081-6136

336. Hans Erich Hintermann CSEM

Materials and Micromechanics Division

Rue Breguet. 2

Neuchatel 2000

SWITZERLAND

AIR MAIL

337. Shinichi Hirano

Mazda R\&D of North America, Inc.

1203 Woodridge Avenue

Ann Arbor, MI 48105

338. Tommy Hiraoka NGK Locke, Inc. 1000 Town Center

Southfield, MI 48075

339. John M. Hobday

U.S. Department of Energy

Morgantown Energy Technology Center

Collins Ferry Road

P.O. Box 880

Morgantown, WV 26507

340. Greg Hoenes

Vista Chemical Company

900 Threadneedle

P.0. Box 19029

Houston, TX 77079-2990

341. Clarence Hoenig

Lawrence Livermore ilational Laboratory

P.O. Box 808, Mail Code L-369

Livermore, CA 94550

342. Thomas Hollstein

Fraunhofer-Institut fur Werkst offmechanik IWM

Wohlerstrabe 11

D-7800 Freiburg GERMANY AIR MAIL 
343. Richard Holt

National Research Council of Canada

Structures and Materials Laboratory

ottawa Ontario KIA OR6

CANADA AIR MAIL

344. Joseph Homeny

University of Illinois

Department of Materials Science and Engineering

105 South Goodwin Avenue

Ceramics Building

Urbana, IL 61801

345. A. T. Hopper

Battelle Columbus

Laboratories

Metals and Ceramics Department

$505 \mathrm{King}$ Avenue

Columbus, OH 43201-2693

346. Michael Horgan

Materials Engineering Magazine

1100 Superior Avenue

Cleveland, $\mathrm{OH} \mathbf{4 4 1 1 4}$

347. Woodie Howe

Coors Technical Ceramics

Company

1100 Commerce Park Drive

Oak Ridge, TN 37830

348. Stephen M. Hsu

National Institute of

Standards and Technology

Gaithersburg, MD 20899

349. Hann S. Huang

Argonne National Laboratory

9700 South Cass Avenue

Argonne, IL 60439-4815

350. Gene Huber

Precision Ferrites \& Ceramics

5576 Corparate Drive

Cypress, CA 90630

351. M. L. Huckabee

GTE Laboratories, Inc.

40 Sylvan Road

Waltham, MA 02254
352. Harold A. Huckins

Princeton Advanced

Technology, Inc.

56 Finley Road

Princeton, NJ 08540

353. Fred R. Huettic

Advanced Magnetics, Inc.

45 Corey Lane

Mendham, N- 07945

354. Bill Huffman

Zircar

110 North Main Street

Florida, NY 10921

355. Brian K. Humphrey

Lubrizol Petroleum Chemicals Co.

3000 Town Center, Suite 1340

Southfield, MI 48075-1201

356. Robert M. Humrick

Dylon Ceramic Technologies

3100 Edgehill Road

Cleveland Heights, $\mathrm{OH} \mathbf{4 4 1 1 8}$

357. Lorretta Inglehart

National Science Foundation

Division of Materials Research

1800 "G" Street, N.W.,

Room 408

Washington, DC 20550

358. Michael S. Inoue

Kyocera International, Inc.

KII Library

8611 Balboa Avenue

San Diego, CA 92123-1580

359. Osama Jadaan

University of WisconsinPlatteville

General Engineering Division

1 University Plaza

Platteville, WI 53818

360. Curtis A. Johnson

General Electric Company Corporate R\&D

Room MB-187

P.0. Box 8

Schenectady, NY 12301 
361. Sylvia Johnson

SRI International

333 Ravenswood Avenue

Menlo Park, CA 94025

362. Thomas A. Johnson

Lanxide Corporation

1300 Marrows Road

P.0. Box 6077

Newark, DE 19714-6077

363. W. S. Johnson

Indiana University

One City Centre, Suite 200

Bloomingtun, IN 47405

364. Jill E. Jonkouski

U.S. Department of Energy

9800 South Cass Avenue

Argonne, IL 60439-4899

365. L. A. Joo

Great Lakes Research

Corporation

P.0. Box 1031

Elizabethton, TN 37643

366. A. D. Joseph

SPX Corporation

700 Terrace Point

Muskegon, MI 49443

367. Adam Jostsons

Australian Nuclear Science \& Technology Organization

Lucas Heights Research Laboratories

New Illawarra Road

Lucas Heights New South Wales

AUSTRALIA AIR MAIL

368. Matthew K. Juneau

Ethyl Corporation

451 Florida Street

Baton Rouge, LA 70801

369. Hartmut Kainer

Didier-Werke AG

Anlagentechnik Wiesbaden

Abraham-Lincoln-Str. 16

D-62. Wiesbaden

GERMANY AIR MAIL
370. Tom Kalamasz

Norton/TRW Ceramics

7A-4 Raymond Avenue

Salem, NH 03079

371. Lyle R. Kallenbach

Phillips Petroleum Company

R\&D

Mai1 Drop:123AL

Bartlesville, OK 74004

372. Nick Kamiya

Kyocera Industrial Ceramics

Corporation

2700 River Road

Des Plaines, IL 60018

373. Roy Kamo

Adiabatics, Inc.

3385 Commerce Park L Live

Columbus, IN 47201

374. S. Kang

GTE Laboratories, Inc.

40 Sylvan Road

Waltham, MA 02254

375. Chih-Chun Kao

Industrial Technology Research Institute

Materials Research Laboratories

195 Chung-Hsing Road, Sec. 4

Chutung Hsinchu 31015 R.O.C.

TAIWAN AIR MAIL

376. Keith R. Karasek

All ied-Signal, Inc.

Engineered Materials Research Center

50 East Algonquin Road

P.0. Box 5016

Des Plaines, IL 60017-5016

377. Robert E. Kasse1

Ceradyne, Inc.

3169 Redhill Avenue

Costa Mesa, CA 92626

378. Allan Katz

Wright Laboratory

Metals and Ceramics Givision WL/MLLM

Wright-Patterson AFB, OH 45433 
379. R. Nathan Katz

Worcester Polytechnic Institute

Dept. of Mechanical Engineering

100 Institute Road

Worcester, MA 01609

380. Ted Kawaguchi

Tokai Carbon America, Inc.

375 Park Avenue, Suite 3802

New York, NY 10152

381. Noritsugu Kawashima

TOSHIBA Corporation

Mechanical Engineering Laboratory

4-1 Ukishima-Cho

Kawasaki-Ku Kawasaki 210

JAPAN AIR MAIL

382. Lisa Kempfer

Penton Publishing

Materials Engineering

1100 Superior Avenue

Cleveland, $\mathrm{OH}$ 44114-2543

383. Frederick L. Kennard, III

General Motors Corporation

AC Rochester

Department 32-24, EB

1300 North Dort Highway

Flint, MI 48556

384. David 0. Kennedy

Lester B. Knight Cast Metals Inc.

549 West Randolph Street

Chicago, IL 60661

385. George Keros

Photon Physics

3175 Penobscot Building

Detroit, MI 48226

386. Pramod K. Khandelwal

General Motors Corporation

Allison Gas Turbine Division

P.0. Box 420, MS :W05

Indianapolis, IN 46206
387. Jim R. Kidwell

Allied-Signal Aerospace

Company

Garrett Auxiliary Power Division

P.0. Box 5227

Phoenix, AZ 85010

388. Han J. Kim

GTE Laboratories, Inc.

40 Sylvan Road

Waltham, MA 02254

389. Shin Kim

Korea Institute of Machinery \& Metals

66 Sangnam-dong, Changwon

Kyungnam 641-010

KOREA AIR MAIL

390. W. C. King

Mack Truck, Z-41

1999 Pennsylvania Avenue

Hagerstown, MD 21740

391. Carol Kirkpatrick

MSE, Inc.

CDIF Technical Library

P.0. Box 3767

Butte, MT 59702

392. Tony Kirn

Caterpillar, Inc.

Defense Products Department, JB7

Peoria, IL 61629

393. James D. Kiser

NASA Lewis Research Center

21000 Brookpark Road, MS:49-3

Cleveland, $\mathrm{OH} 44135$

394. Max Klein

Gas Research Institute

Thermodynamics

8600 West Bryn Mawr Avenue

Chicago, IL 60631

395. Richard N. Kleiner

Coors Ceramics Company

4545 McIntyre Street

Golden, CO 80403 
396. Stanley J. Klima

NASA Lewis Research Center

21000 Brookpark Road

MS:6-1

Cleveland, $\mathrm{OH} 44135$

397. Chris E. Knapp

Norton Advanced Ceramics of Canada Ltd.

8001 Daly Street

Niagara Falls, Ontario L2G 6S2

CANADA AIR MAIL

398. Albert S. Kobayashi

University of Washington

Mechanical Engineering Department

MS:FU10

Seattle, WA 98195

399. Shigeki Kobayashi

Toyota Central Research Labs, Inc.

Nagakute Aichi 480-11

JAPAN AIR MAIL

400. Richard A. Kole

Z-Tech Corporation

8 Dow Road

Bow, NH 03304

401. E. Kostiner

University of Connecticut

Chemistry Department, U-60

Storrs, CT 06269-3060

402. Kenneth A. Kovaly

Technical Insights, Inc.

P.0. Box 1304

Fort Lee, NJ 07024-9967

403. Ralph G. Kraft

Spraying Systems Company

North Avenue at Schmale Road

Wheaton, IL 60189-7900

404. Saunders B. Kramer

U.S. Department of Energy

Advanced Propulsion Division CE-322, Forrestal Building

Washington, DC 20585
405. Arthur Kranish

Trends Publishing, Inc.

1079 National Press Building

Washington, DC 20045

406. A. S. Krieger

Radiation Science, Inc.

P.O. Box 293

Beimont, MA 02178

407. Pietar Krijgsman

Ceramic Design International

Holding B.V.

P. 0. Box 68

Hattem 8050-AB

THE NETHERLANDS AIR MAIL

408. Waltraud M. Kriven

University of 117 inois

Materials Science and

Engineering Department

105 South Goodwin Avenue

Urbana, IL 61801

409. Edward J. Kubel, Jr.

ASM International Advanced

Materials \& Processes

Materials Park, OH 44073

410. Dave Kupperman

Argonne National Laboratory

9700 South Cass Avenue

Argonne, IL 60439

411. Oh-Hun Kwon

Norton Company

Advanced Ceramics

Goddard Road

Northboro, MA 01532-1545

412. W. J. Lackey

Georgia Institute of Technology

Material: Science and Technology

At lanta, GA 30332

413. Jai Lala

Tenmat Ltd.

40 Somers Road

Rugby Warwickshire CV22 7DH

ENGLAND AIR MAIL 
414. Hari S. Lamba

General Motors Corporation

Electro-Motive Division

9301 West 55th Street

LaGrange, IL 60525

415. Richard L. Landingham

Lawrence Livermore National Laboratory

Ceramics, Corrosion, and

Thermochemistry

P. O. Box 808, L-369

Livermore, CA 94550

416. Charles J. Landry Chand Kare Technical Ceramics 712 Flat Hill Road Lumenburg, MA 01462

417. Manfred W. Langer

Volkswagen AG

Material Technology

3180 Wolfsburg 1

GERMANY AIR MAIL

418. James Lankford

Southwest Research Institute

Department of Materials

Sciences

6220 Culebra Road

San Antonio, TX 78228-0510

419. Stanley B. Lasday

Business News Publishing Co.

Manor Oak One

1910 Cochran Road, Suite 630

Pittsburgh, PA 15220

420. Mark S. Laser

Solar Turbines, Inc.

2211 Erie Street

San Diego, CA 92110

421. S. K. Lau

Carborundum Company

Technology Division

P.0. Box 832, B-100

Niagara Falls, NY 14302

422. Edward A. Lauder

Advanced Composite Materials

Corporation

1525 South Buncombe Road

Greer, SC 29651-9208
423. J. Lawrence Lauderdale

Babcock \& Wilcox

Contract Research Division 1850 "K" Street, Suite 950

Washington, DC 20006

424. Harry A. Lawler

Carborundum Company

Technology Division

P.O. Box 832

Niagara Falls, NY 14302

425. Jean F. LeCostaouec

Textron Speciality Materials

2 Industrial Avenue

Lowe11, MA 01851

426. Benson P. Lee

Interscience, Inc.

9718 Lake Shore Boulevard

Cleveland, $\mathrm{OH} 44108$

427. Burtrand I. Lee

Clemson University

Department of Ceramic Engineering

$0 l$ in $\mathrm{Hall}$

Clemson, SC 29634-0907

428. June-Gunn Lee

KIST

Structural Ceramic Lab

P.0. Box 131, Cheong-Ryang

Seoul 130-650

KOREA AIR MAIL

429. Ran-Rong Lee

Ceramics Process Systems Corporation

155 Fortune Boulevard

Milford, MA 01757

430. Stan Levine

NASA Lewis Research Center

21000 Bruokpark Road

MS : 49-3

Cleveland, OH 44135

431. Alan V. Levy

Lawrence Berkeley Laboratory

One Cyclotron Road, MS:62-203

Berke ley, CA 94720 
432. Ai-Kang Li

Materials Research Laboratories, ITRI

195-5 Chung-Hsing Road, Sec. 4

Chutung Hsinchu 31015 R.O.C.

TAIWAN AIR MAIL

433. Winston W. Liang

Hong Kong Industrial

Technology Centre Co. Ltd.

78 Tat Chee Avenue

$4 / F$, HKPC Building

Howloon

HONG KONG

AIR MAIL

434. Robert Licht

Norton Company

Advanced Ceramics

Goddard Road

Northboro, MA 01532-1545

435. E. Lilley

Norton Company

Advanced Ceramics

Goddard Road

Northboro, MA 01532-1545

436. Laura J. Lindberg

Allied-Signal Aerospace

Company

Garrett Fluid Systems Division

1300 West Warner

MS: 93-901-1207-4TT

P.0. Box 22200

Tempe, AZ 85284-2200

437. Leonard C. Lindgren

General Motors Corporation

Allison Gas Turbine Division

P.0. Box 420, Speed Code:T-20A

Indianapolis, IN 46206-0420

438. Hans A. Lindner

Cremer Forschungsinstitut GmbH\&CO.KG

Oeslauer Strasse 35

D-8633 Rodental 8866

GERMANY AIR MAIL
439. Ronald E. Loehman

Sandia National Laboratories

Chemistry \& Ceramics Department 1840

P.0. Box 5800

Albuquerque, NM 87185

440. Jeffrey C. Logas

Winona State University

Composite Materials

Engineering

115 Pasteur Hall

Winona, MN 55987

441. Bill Long

Babcock \& Wilcox

P.0. Box 11165

Lynchburg, VA 24506

442. William D. Long

Wacker Chemicals (USA), Inc.

ESK Engineered Ceramics

50 Locust Avenue

New Canaan, CT 06840

443. L. A. Lott

EG\&G Idaho, Inc.

Idaho National Engineering Laboratory

P.0. Box 1625

Idaho Falls, ID 83415-2209

444. Raouf 0. Loutfy

MER Corporation

7960 South Kolb Road

Tucson, AZ 85706

445. Gordon R. Love

Aluminum Company of America

Alcoa Technical Center

Alcoa Center, PA 15069

446. Lydia Luckevich

Ortech International

2395 Speakman Drive

Mississauga Ontario L5K 1B3

CANADA AIR MAIL 
447. James W. MacBeth

Carborundum Company

Structural Ceramics Division

P.0. Box 1054

Niagara Falls, NY 14302

448. H. Maclaren

General Electric Company

Thomson Laboratory, Materials

Engimeering 36807

1000 Hestern Avenue

Lynn, MA 01910

449. George Maczura

Aluminum Company of America Industrial Chemicals Division 670 One Allegheny Square

Pittsburgh, PA 15212

450. David Maginnis

Tinker AFB

OC-ALC/LIIRE

Tinker AFB OK 73145-5989

451. Frank Maginnis

Aspen Research, Inc.

220 Industrial Boulevard

Moore, OK 73160

452. Tai-il Mah

Universal Energy Systems, Inc.

Ceramics and Composites

Research

4401 Dayton -Xenia Road

Dayton, $\mathrm{OH} 45432$

453. Kenneth M. Maillar

Barbou' Stockwell Company

83 Linskey Way

Cambridge, MA 02142

454. Lorenzo Majno

Instron Corporation

100 Royall Street

Canton, MA 02021

455. S. G. Malghan

National Institute of Standards and Technology

I-270 \& Clopper Road

Gaithersburg, MD 20899
456. Lars Maimrup

United Turbine $A B$

Box 13027

MaImo S-200 44

SWEDEN AIR MAIL

457. John Hangels

Ceradyne, Inc.

3169 Redhil1 Avenue

Costa Mesar-CA 92626

458. Russell V. Mann

Matec Applied Sciences, Inc.

75 South Street

Hopkinton, MA 01748

459. William R. Manning

Champion Aviation Products Division

01d Norris Road

P.0. Box 686

Liberty, SC 29657

460. Ken Marnoch

Amercom, Inc.

8928 Fullbright Avenue

Chatsworth, CA 91311

461. Robert A. Marra

A. uminum Company of America

Alcoa Technical Center

Advanced Ceramics Center - E

Alcoa Center, PA 15069

462. Chauncey L. Martin

3M Company

3M Center, Building 60-1N-01

St. Paul, MN 55144

463. Steven C. Martin

Advanced Refractory Technologies, Inc.

699 Hertel Avenue

Buffalo, NY 142.07

464. Kelly J. Mather

Williams International

Corporation

2280 West Maple Road

P.0. Box 200

Walled Lake, MI 48088 
465. James $P$. Mathers

3M Company

$3 M$ Center

Butlding 201-3N-06

St. Paut, MN 55144

466. Marshall Mayer

Instron Corporation

3815 Presidential Parkway, Suite 100

Atlanta, GA 30340

467. Ron Mayville

Arthur D. Littie, Inc.

15-163 Acorn Park

Cambridge, MA 02140

468. F. N. Mazadarany

General Electric Company

Research Laboratory

Building K-1, Room MiB-159

P.0. Box 8

Schenectady, NY 12301

469. Jaines W. McCauley

Alfred University

NYS College of Ceramics

Binns-Merrill Hall

Alfred, NY 14802

470. Carolyn McCormick

Allied-Signal Aerospace Company

Garrett Auxiliary Power

Division

Bidg. 1303-206

P.O. Box 5227, MS:9317-2

Phoenix, AZ 85010

471. Louis R. McCreight

2763 San Ramon Drive

Rancho Palos Verdes, CA 90274

472. Colin F. McDonald

McDonald Thermal Engineering

1730 Castellana Road

La Jolla, CA 92037

473. B. J. McEntire

Norton Company, TRW Ceramics

Goddard Road

Northboro, MA 01532-1545
474. Chuck McFadden

Coors Ceramics Company

600 9th Street

Golden, CO 80401

475. Henry McFadden

Magnetic Bearings, Inc.

Engineering Library

609 Rock Road

Radford, VA. 24141

476. Thomas D. McGee

Iowa State University

Materiais Science and

Engineering Department 110 Engineering Annex

Ames, IA 50011

477. Carol Mc.Gill

Corning Inc.

Sullivan Park, FR-02-08

Corning, NY 14831

473. T. C. McLaren

Cameron Forged Products Company

P.0. Box 1212

Houston, TX 77251-1212

479. James McLaughl in

Sundstrand Porer Siystems

4400 Ruffin Road

P.O. Box 85757

San Diego, CA 921136-5757

480. Arthur F. McLean

6225 North Camino Almonte

Tucson, AZ 85718

481. Matt McMonigle

U.S. Department of Energy

Improved Energy Productivity Division

Forrestal Building, CE-231

Washington, DC 20585

482. Dennis McMurtry

EG\&G Idaho, Inc.

Idaho National Engineering Laboratory

P.0. Box 1625

Idaho Falls, ID 83415 
483. D. B. Meadowcroft

National Power Technology and Environmental Centre

Kelvin Avenue

Leatherhead Surrey KT22 7SE

ENGLAND AIR MAIL

484. Jo Meglen

11004 Birdfoot Court

Reston, VA 22091

485. Pankaj K. Mehrotra

Kennametal, Inc.

P.0. Box 639

Greensburg, PA 15601

486. Joseph J. Meindl

Reynolds International, Inc.

6603 Hest Broad Street

P.0. Box 27002

Richmond, VA 23261-7003

487. Michael D. Meiser

Allied-Signal Aerospace Company

Garrett Ceramic Components Division

19800 South Van Ness Avenue

Torrance, CA 90509

488. George Messenger

National Research Council of Canada

Engine Laboratory

Building M-7

Ottawa Ontario K1A OR6

CANADA AIR MAIL

489. D. Messier

U.S. Army Materials Technology L.aboratory

SLCMT-EMC

405 Arsenal Street

Watertown, MA 02172-0001

490. Gary L. Messing

Pennsyivania State University

Ceramic Science and Engineering Departinent

119 Steidle Building

University Park, PA 16802
491. Arthur G. Metcalfe

Arthur G. Metcalfe and

Associates, Inc.

2108 East 24th Street

National City, CA 91950

492. R. Metselaar

Eindhoven University

Centre for Technical Ceramics

P.0. Box 5.13

Eindhoven $5600 \mathrm{MB}$

THE NETHERLANDS

AIR MAIL

493. Nancy S. Meyers

U.S. Department of Energy

Transportation Technologies

CE-30, Forrestal Building 68-094

Washington, DC 20585

494. David J. Michael

Harbison-Walker Refractories Company

P. 0. Box 98037

Pittsburgh, PA 15227

495. Ken Michaels

Chrysier Motors Corporation

Ceramics Development Metallurgical Processes

P.0. Box 1118, CIMS:418-17-09

Detroit, MI 48288

496. Bernd Michel

Institute of Mechanics

Fracture and Micromechanics Department

P.O. Box 408

D-9010 Chemnitz

GERMANY AIR MAIL

497. David E. Miles

Commission of the European Communities

rue de la Loi, 200

B-1049 Brussels

BELGIUM

AIR MAIL.

498. John V. Milewski

Superkinetics, Inc.

P.0. Box 8029

Santa Fe, NM 87504 
499. Carl E. Miller

$A C$ Rochester

1300 North Dort Highway,

MS : 32-31

Engineering Building $B$

Flint, MI 48556

500. Mike Miller

McGraw-Hill Aviation Week

Performance Materials

1156 15th Street, N.W.

Washington, DC 20005

501. Charles W. Miller, Jr.

Centorr Furnaces/Vacuum Industries

542 Amherst Street

Nashua, NH 03063

502. R. Mininni

Enichem America

2000 Cornwall Road

Monmouth Junction, NJ 08852

503. Michele V. Mitchell

Allied-Signal Aerospace Company

Garrett Ceramic Components Division

19800 South Van Ness Avenue

Torrance, CA 90501-1149

504. Howard Mizuhara

GTE - WESGO

477 Harbor Boulevard

Belmont, CA 94002

505. Helen Moeller

Babcock \& Wilcox

P.0. Box 11165

Lynchburg, VA 24506-1165

506. Francois R. Mollard

Metalworking Technology, Inc.

1450 Scalp Avenue

Johnstown, PA 15904

507. Phil Mooney

Panametrics

NDE Division

221 Crescent Street

Waltham, MA 02254
508. Thomas More 1

Ricardo North America

645 Blackhawk Drive

Westmont, IL 60559

509. Geoffrey P. Morris

3M Company

3M Traffic Control Materials Division

B1dg. 209-BW-10, 3M Center

St. Pau1, MN 55144-1000

510. Jay A. Morrison

Rolls-Royce, Inc.

Engineering and Information Center, Overlook 1

2849 Paces Ferry Road, Suite 450

At lanta, GA 30339-3769

511. Joel P. Moskowitz

Ceradyne, Inc.

3169 Redhill Avenue

Costa Mesa, CA 92626

512. Brij Moudgit

University of Florida

Material Science and Engineering

Gainesville, FL 32611

513. Christoph J. Mueller

Sprechsaal Publishing Group

P.0. Box 2962, Mauer 2 D-8630 Coburg

GERMANY AIR MAIL

514. Thomas W. Mullan

Vapor Technologies Inc.

345 Route 17 South

Upper Saddle River. NJ 07458

515. M. K. Murthy

MKM Consultants International

10 Avoca Avenue, Unit 1906

Toronto Ontario MAT 2B7

CANADA AIR MAIL

516. Solomon Musikant

TransCon Technologies, Inc.

Materials Science \& Engineering

1508 Waynesboro Road

Paoli, PA 19301 
517. David L. Mustoe

Custom Technical Ceramics

8041 West I-70 Service Road, Unit 6

Arvada, CO 80002

518. Curtis V. Nakaishi

U.S. Department of Energy

Morgantown Energy Technology Center

Collins Ferry Road

P.0. Box 880

Morgantown, WV 26507-0880

519. Yoshio Nakamura

Faicera Research Institute

2-5-8 Hiyakunin-cho Shinjuku-Ko

Tokyo

JAPAN AIR MAIL

520. K. S. Narasimhan

Hoeganaes Corporation

River Road

Riverton, NJ 08077

521. Samuel Natansohn

GTE Laboratories, Inc.

40 Sylvan Road

Waltham, MA 02254

522. Robert Naum

Applied Resources, Inc.

P.0. Box 241

Pittsford, NY 14534

523. Malcolm Naylor

Cummins Engine Company, Inc.

P.O. Box 3005, Mail Code 50183

Columbus, IN 47202-3005

524. Jeffrey Neil

GTE Laboratories, Inc.

40 Sylvan Road

Waitham, MA 02254

525. Fred A. Nichols

Argonne National Laboratory

9700 South Cass Avenue

MCT - Building 212

Argonne, IL 60439
526. H. Nickel

Furschungszentrum Jüelich (KFA)

P.O. Box 1913

Jüelich 1-5170 BRD NRW

GERMANY AIR MAIL

527. Dale E. Niesz

Rutgers University

Center for Ceramic Research

P.0. Box 909

Piscataway, NJ 08855-0909

528. David M. Nissley

United Technologies Corporation

Pratt \& Whitney Aircraft

400 Main Street, MS: 163-10

East Hartford, CT 06108

529. Richard D. Nixdorf

ReMaxCo Technologies, Inc.

11317 Snyder Road

Knoxville, TN 37932

530. Bernard North

Kennametal, Inc.

P.0. Box 639

Greensburg, PA 15601

531. Bruce F. Novich

Ceramics Process Systems Corporation

155 Fortune Boulevard

Milford, MA 01757

532. Daniel Oblas

GTE Laboratories, Inc.

40 Sylvan Road

Waltham, MA 02254

533. Don Ohanehi

Magnetic Bearings, Inc.

1908 Sussex Road

Blacksburg, VA 24060

534. Robert Orenstein

General Electric Company

55-112, River Road

Schenectady, NY 12345 
535. Norb Osborn

Aerodyne Dallas

151 Regal Row, Suite 120

Dallas, TX 75247

536. A. M. Paddick

BP International Limited

BP Research Centre, Main Library

Chertsey Road

Sunbury-on-Thames

Middlesex TW16 7LN

UNITED KINGDOM AIR MAIL

537. Russe11 J. Page

Kanthal-Artcor

3001 Redhill Avenue, II-109

Costa Mesa, CA 92705

538. Richard Palicka

Cercom, Inc.

1960 Watson Way

Vista, CA 92083

539. Muktesh Pal iwal

GTE Products Corporation

Hawes Street

Towanda, PA 18848

540. Joseph E. Palko

General Electric Company

55-113, River Road

Schenectady, NY 12345

541. Hayne Palmour, III

North Carolina State University

Materials Science and

Engineering Dept.

Raleigh, NC 27605-7905

542. Joseph N. Panzarino

Norton Company

Advanced Ceramics

Goddard Road

Northboro, MA 01532-1545

543. Pellegrino Papa

Corning Inc.

MP-WX-02-1

Corning, NY 14831
544. E. Beth Pardue

Technology for Energy

Corporation

One Energy Center

P.0. Box 22996

Knoxville, TN 37933-0996

545. Soon C. Park

3M Company

$3 M$ Center..

Building 142-4N-02

P. O. Box 2963

St. Paut, MN 55144

546. Hartmut Paschke

Schott Glaswerke

Christoph-Dorner-Strasse 29

D-8300 Landshut

GERMANY AIR MAIL

547. Marina R. Pascucci

GTE Laboratories, Inc.

40 Sylvan Road

Waltham, MA 02254

548. James W. Patten

Cummins Engine

Company, Inc.

Materials Engineering

P.0. Box 3005, Mail

Code 50183

Columbus, IN 47202-3005

549. Robert A. Penty

Eastman Kodak Company

KAD/D73 - 35612

901 Elmgrove Road

Rochester, NY 14653

550. Robert W. Pepper

Textron Specialty Materials

2 Industrial Avenue

Lowe 11, MA 01851

551. Peter Perdue

Detroit Diesel Corporation

Research Advanced Development Group

13400 West Outer Drive, Speed Code A-07

Detroit, MI 48239-4001 
552. Bruce Peters

Dow Chemical Company

Building 52

Midland, MI 48667

553. John J. Petrovic

Los Al amos National Laboratory

Group MST-4, MS: 6771

Los Alamos, NM 87545

554. Frederick S. Pettit

University of Pittsburgh

Pittsburgh, PA 15261

555. Ben A. Phillips

Phillips Engineering Company

721 Pleasant Street

St. Joseph, MI 49085

556. Richard C. Phoenix Ohmtek, Inc.

2160 Liberty Drive

Niagara Falls, NY 14302

557. Bruce J. Pletka

Michigan Technological University

Meta?lurgical and Materials

Engineering Department

Houghton, MI 49931

558. John P. Pollinger

Garrett Ceramic Components

19800 Van Ness Avenue

Torrance, CA 90501

559. P. Popper

High Technology Ceramics International Journal

22 Pembroke Drive

Westlands Newcastle-under-Lyme Staffs ST5 2JN

ENGLAND AIR MAIL

560. F. Porz

Universitat Karlsruhe

Institut fur Keramik Im

Maschinendau

Postfach 6980

D-7500 Karlsruhe GERMANY
561. Harry L. Potma

Royal Netherlands Embassy

Science and Technology

4200 Linnean Avenue, N.W.

Washington, DC 20008

562. Bob R. Powell

General Motors Research

Laboratories

Metallurgy. Department

30500 Mound Road

Box 9055

Warren, MI 48090-9055

563. Stephen C. Pred

ICD Group, Inc.

1100 Valley Brook Avenue

Lyndhurst, NJ 07071

564. Karl M. Prewo

United Technologies Research Cent or

411 Silver Lane

MS : 24

East Hartford, CT 06108

565. Peler E. Price

Industrial Materials

Technology, Inc.

P.n. Box 9565

Andover, MA 01810

566. Joseph M. Proud

GTE Laboratories, Inc.

Materials Science Laboratory 40 Sylvan Road

Waltham, MA 02254

567. Vimal K. Pujari

Norton Company

Advanced Ceramics

Goddard Road

Northboro, MA 01532-1545

568. George Quinn

National Institute of

Standards and Technology

Ceramics Division, Bldg. 223

Gaithersburg, MD 20899 
569. Ramas V. Raman

Ceracon, Inc.

1101 North Market Boulevard, Suite 9

Sacramento, CA 95834

570. Charles F. Rapp

Owens Corning Fiberglass

2790 Columbus Road

Granville; OH 43023-1200

571. Dennis W. Readey

Colorado School of Mines

Department of Metallurgy and Materials Engineering

Golden, CO 80401

572. Wilfred J. Rebello

PAR Enterprises, Inc.

12601 Clifton Hunt Lane

Clifton, VA 22024

573. Harold Rechter

Chicago Fire Brick Company

R\&D

7531 South Ashland Avenue

Chicago, IL 60620

574. Robert R. Reeber

U.S. Army Research Office

P.0. Box 12211

Research Triangle Park, NC 27709

575. K. L. Reifsnider

Virginia Polytechnic Institute and State University

Department of Engineering

Science and Mechanics

Blacksburg, VA 24061

576. Paut E. Rempes

McDonnell Douglass Missle

Systems Company

P.0. Box 516,

Mail Code: 1066086

St. Louis, MO 63166-0516

577. Gopal S. Revankar

John Deere Company

Metals Research

3300 River Drive

Moline, IL 61265
578. K. T. Rhee

Rutgers University

Mechanical Engineering

P.0. Box 909

Piscataway, NJ 08854

579. James Rhodes

Advanced Composite Materials Corporation

1525 South Buncombe Road

Greer, SC 29651

580. Roy W. Rice

W. R. Grace and Company

7379 Route 32

Columbia, MD 21044

581. David W. Richerson

2093 East Delmont Drive

Salt Lake City, UT 84117

582. Tomas Richter

J. H. France Refractories

1944 Clarence Road

Snow Shoe, PA 16874

583. Michel Rigaud

Ecole Polytechnique

Campus Universite De Montreal

P.0. Box 6079, Station A

Montrea 7, P.Q Quebec H3C 3A7

CANADA AIR MAIL

584. R. E. Riman

Rutgers University

Ceramics Engineering Department

P.0. Box 909

Piscataway, NJ 08855-0909

585. Barry Ringstrom

Superior Graphite Company

P.O. Box 2373

Smyrna, GA 30081

586. John E. Ritter

University of Massachusetts

Mechanical Engineering Department

Amherst, MA 01003 
587. Frank L. Roberge

Allied-Signal Aerospace Company

Garrett Auxiliary Power Division

P.0. Box 5227

Phoenix, AZ 85010

588. W. Eric Roberts

Advanced Ceramic Technology, Inc.

990 " $F$ " Enterprise Street

Orange, CA 92667

589. Martha Rohr

U.S. Department of Energy

DOE Oak Ridge Field Office

Building 4500N

P.0. Box 2008, MS: 6269

Oak Ridge, TN 37831-6269

590. Y. G. Roman

TNO TPD Keramick

P.O. Box 595

Einhoven 5600 AN

HOLLAND AIR MAIL

591. Mark D. Roos

Carborundum Company

P.0. Box 156

Niagara Falls, NY 14302

592. Michael Rossetti

Arthur D. Little, Inc.

15 Acorn Park

Cambridge, MA 01240

593. Barry R. Rossing

Lanxide Corporation

1300 Marrows Road

Newark, DE 19714-6077

594. Steven L. Rotz

Lubrizol Corporation

29400 Lakel and Boulevard

Wickl iffe, OH 44092

595. Bruce Rubinger

Global Competitiveness, Inc.

One Devonshire Place,

Suite 1011

Boston, MA 02109
596. Robert Ruh

Wright Laboratory

WL/MLLM

Wright-Patterson AFB, OH 45433

597. Robert J. Russ:11

17 Highgate Road

Framingham, MA 01701

598. L. Willian Sahley

Supermaterials Company

$24400 \mathrm{Highl}$ and Road

Richmond Heights, OH 44143

599. Jon Salem

NASA Lewis Research Center

21000 Brookpark Center

Cleveland, $\mathrm{OH} 44135$

600. W. A. Sanders NASA Lewis Research Center 21000 Brookpark Road,

MS: $49-3$

Cleveland, OH 44135

601. J. Sankar North Carolina A\&T State University

Department of Mechanical Engineering

Greensboro, NC 27411

602. Yasushi Sato

NGK Spark Plugs (U.S.A.), Inc.

1200 Business Center Drive, Suite 300

Mt. Prospect, IL 60056

603. Maxine L. Savitz.

Allied-Signal Aerospace Company

Garrett Ceramic Components Division

19800 South Van Ness Avenue

Torrance, CA 90501

604. Ashok Saxena

Georgia Institute of Technology

Materials Engineering

Atlanta, GA 3033z-0245 
605. David W. Scanlon

Instron Corporation

100 Royall Street

Canton, MA 02021

606. Charles A. Schacht

Schacht Consulting Services

12 Holl and Road

Pittsburgh, PA 15235

607. James Schienle

Allied-Signal Aerospace Company

Garrett Auxiliary Power Division

2739 East Washington Street

P.0. Box 5227, MS:1302-2P

Phoenix, AZ 85010

608. John C. Schneider

San Juan Technologies

P.0. Box 49326

Colorado Springs, CO 80949-9326

609. Gary Schnittgrund

Rocketdyne, BAO5

6633 Canoga Avenue

Canoga Park, CA 91303

610. Mark Schomp

Lonza, Inc.

Corporate Headquarters

17-17 Route 208

Fair Lann, NJ 07410

611. Joop Schoonman

Delft University of Technology

Laboratory for Inorganic Chemistry

P.0. Box 5045

2600 GA Delft

THE NETHERLANDS

AIR MAIL

612. John Schuldies

Industrial Ceramic

Technology, Inc.

37 Enterprise Drive

Ann Arbor, MI 48103
613. Robert B. Schuiz

U.S. Department of Energy

Office of Transportation Materials

CE-34, Forrestal Building

Washington, DC 20585

614. Murray A. Schwartz

Materials Technology Consulting, Inc.

30 Orchard Way, North

Potomac, MD 20854

615. Peter Schwarzkopf

SRI International

333 Ravenswood Avenue

Menlo Park, CA 94025

616. Thomas C. Schweizer

Princeton Economic Research, Inc.

12300 Twinbrook Pkwy., Suite 650

Rockville, MD 20852

617. William T. Schwessinger

Multi-Arc Scientific Coatings

1064 Chicago Road

Troy, MI 48083-4297

618. W. D. Scott

University of Washington

Materials Science Department

Mail Stop:FB10

Seattle, WA 98195

619. Nancy Scoville

Thermo Electron Technologies

74 West Street

P.0. Box 9046

Wa1 tham, MA 02254-9046

620. Brian Seegmiller

Coors Ceramics Company

600 9th Street

Golden, CO 80401 
621. T. B. Selover

AICRE/DIPPR

3575 Traver Road

Shaker Heights, $\mathrm{OH} 44122$

622. J. H. Selverian

GTE Laboratories, Inc.

40 Sylvan Road

Wal tham, MA 02254

623. Charles E. Semler

Semler Materials Services

4160 Mumford Court

Columbus, $\mathrm{OH} 43220$

624. Thomas Service

Service Engineering Laboratory

324 Wells Street

Greenfield, MA 01301

625. Kish Seth

Ethyl Corporation

R\&D Laboratories

P.0. Box 341

Baton Rouge, LA 70821

626. Karleen Seybold

Allied-Signal Aerospace Company

Garrett Auxiliary Power Division

P.0. Box 5227

Phoenix, AZ 85010

627. William J. Shack Argonne National Laboratory 9700 South Cass Avenue Building 212

Argonne, IL 60439

628. Peter T. B. Shaffer

Technical Ceramics Laboratories, Inc. 4045 Nine/McFarland Drive Alpharetta, GA 30201

629. Richard K. Shaltens NASA Lewis Research Center 21000 Brookpark Road, MS: $301-2$

Cleveland, $\mathrm{OH} 44135$
630. Robert S. Shane

238 Hemlock Road

Wynnewood, PA 19096

631. Daniel Shanefield

Rutgers University

Ceramics Engineering Department

P.0. Box 909

Piscataway,- NJ 08855-0909

632. Ravi Shankar

Chromalloy

Research and Technology Division

Blaisdell Road

Orangeburg, NY 10962

633. Terence Sheehan

Alpex Wheel Company

727 Berkley Street

New Milford, NJ 07646

634. Dinesh K. Shetty

University of Utah

304 EMRO, Dept. of Materials Science and Engineering

Salt Lake City, UT 84112

635. Masahide Shimizu

Ceramic Society of Japan

2-2-503 Takiyama 6-chome

Higashikurume-Shi Tokyo 203

JAPAN AIR MRIL

636. John Shipinski

Toyota Technical Center U.S.A., Inc.

Technical Research Department 2000 Town Center, Suite 500

Southfield, MI 48075

637. Thomas Shreves

American Ceramic Society, Inc.

Library

757 Brooksedge Plaza Drive Westerville, $\mathrm{OH}$ 43081-2821

638. Jack D. Sibold

Coors Ceramics Company

Contracts for Corporate

Technology

4545 McIntyre Street

Golden, CO 80403 
639. George H. Siegel

Point North Associates, Inc. P.0. Box 907

Madison, NJ 07940

640. Richard Silberglitt

Technology Assessment and Transfer, Inc.

133 Defense Highway, \#212

Annapolis, MD 21401

641. Mary Silverberg

Norton Company

Advanced Ceramics Library

Goddard Road

Northboro, MA 01532-1545

642. Gurpreet Singh

Department of the Navy

Internal Combustion \& Gas Turbine Engine Division Code $56 \times 31$

Washington, DC 20362-5101

643. Maurice J. Sinnott

University of Michigan

Chemical and Metallurgical Engineering

5106 IST Building

Ann Arbor, MI 48109-2099

644. John Skildum

3M Company

$3 M$ Center

Building 224-25-25

St. Paul, MN 55144

645. David P. Smith

Hoskins, Rees \& Smith

1910 Cochran Road

Manor Oak II, Suite 658

Pittsburgh, PA 15220

646. Richard H. Smoak

Smoak \& Associates

3554 Hollyslope Road

Altadena, CA 91001-3923
647. Jay R. Smyth

Allied-Signal Aerospace

Company

Garreti Auxiliary Power Division

2739 East Washington Street

P.0. Box 5227

MS : $93-173 / 1303-207$

Phoenix, AZ 85010

648. Edward A. Snajdr

Premier Refractories and Chemicals, Inc.

P.0. Box 392

Findlay, $\mathrm{OH} 44815$

649. Rafal A. Sobotowski

British Petroleum Company

Technical Center, Broadway

3092 Broadway Avenue

Clevel and, OH 44115

650. A. G. Solomah

SAC International Ltd.

1445 Bonhi11 Road, \#13

Mississauga Ontario L5T IV3

CANADA AIR MAIL

651. S. Somiya

Nishi Tokyo University

3-7-19 Seijo, Setagaya

Tokyo 157

JAPAN AIR MAIL.

652. Boyd W. Sorenson

DuPont Lanxide Composites

1300 Marrows Road

P.0. Box 6077

Neward, DE 19707

653. Charles A. Sorrell

U.S. Department of Energy

Advanced Industrial

Concepts Division

CE-232, Forrestal

Building

Washington, DC 20585 
654. C. Spencer

EA Technology

Capenhurst Chester

CH1 6ES

UNITED KINGDOM AIR MAIL.

655. Allen Spizzo

Hercules, Inc.

Hercules Plaza

Wilinington, DE 19894

656. Richard M. Spriggs

Alfred University

Center for Advanced Ceramic Terhnology

Alfred, NY 14802

657. Charles Spuckler

NASA Lewis Research Centel

21000 Brookpark Road

MS: 5-11

Cleveland, OH 44135-3191

658. M. Srinivasan

Material Soluitions

P.0. Box 663

Grand Island, NY 14702-0663

659. Gordon 1.. Starr

Cumr. is Engine Company, Inc.

Design \& Technology

P.0. Box 3005

Mail Code 50182

Columbus, IN 47202-3005

660. Jim Stevenson

Windrock, Incorporated

154 Fairbanks Plaza

Oak Ridge, TN 37830

661. Tom Stilliwagon

Allied-Signal Aerospace Company

Garrett Ceramic Components Division

19800 South Van Ness Avenue

Torrance, CA 90501

662. Harold L. Stocker

General Motors Corporation

Allison Gas Turbine Division P.0. Box 420

Indianapolis, IN 46206
663. Paul D. Stone

Dow Chemical USA

1776 "Eye" Straet, N.W., Suite 575

Nashington, DC 20006

664. Roger S. Storm

Carborundum Company

Technology Division

P. O. Box 337

Niaqara Falls, NY 14302-0337

665. Peter A. Stranges

4 Chittenden Lane

Owings Mills, MD 21117

666. F. W. Stringer

Aero \& Industrial Technology Ltd.

P.0. Box 46, Wood Top

Burnley Lancashire BBII $4 B X$

UNITED KINGNOH AIR MAIL

667. Thomas N. Strom

NASA Lewis Research renter

21000 Brookpark Road

MS : 86-6

Cleveland, OH 44135

668. M. F. Stroosnijder

Institute for Advanced

Materials

Joint Research Centre

21020 Ispra (VA)

ITALY AIR MAIL

659. Karsten Styhr

30604 Ganado Drive

Rancho Palos Verdes, CA 90274

670. T. S. Sudarshan

Materials Modification, Inc.

2929-Pl Eskridge Cenier

Fairfax, VA 22031

671. M. J. Sumdaresan

University of Miami

Mechanical Engineering Department

P.0. Box 248294

Coral Gables, FL 33124 
672. Patrick L. Sutton

U.S. Department of Energy

Advanced Propulsion Division

CE.-322, Forrestal Building

Washington, DC 20585

673. Willard H. Sutton

United Technologies

Corporation

Research Center, MS: 24

Silver Lane

East Hartford, CT 06108

674. Ron Sviben

100 Indel Avenue

Rancocas, NJ 08073

675. J. J. Swab

U.S. Army Materials Technology Laboratory

Ceramics Research Division

SLCNT - EMC

405 Arsenal Street

Watertown, MA 02172

676. Robert E. Swanson

Metalworking Technology, Inc.

1450 Scalp Avenue

Johnstown, PA 15904

677. Scott L. Swartz

Battelle Columbus

Laboratories

Metals and Ceramics

505 King Avenue

Columbus, $\mathrm{OH} 43201$

678. Steve Szaruga

Air Force Wright Aeronautical Laboratory

Materials Directorate

WL/MLBC

Wright-Patterson

$A F B, O H \quad 45433-6533$

679. Yo Tajima

NGK Spark Plug Company, Ltd.

NTK Technical Ceramic Division 2808 Iwasaki

Komaki-shi Aichi-ken 485

JAPAN AIR MAIL
680. Fred Teeter

5 Tralee Terrace

cast Amherst, NY 14051

681. Monika 0. Ten Eyck

Carborvilum Company

Technology Division

P.0. Box 832

Niagara Falls, NY 14302

682. David $F$. Thompson

Corning Glass Works

SP-DV-02-1

Corning, NY 14831

683. Merle L. Thorpe

Hobart Tafa Technologies, Inc.

146 Pembroke Road

Concord, NH 03301

684. Eberhard Tieienbacher

Daimler-Benz AG Abt. FIS

Mercedes-Strabe 136

Stuttgart 60

GERMANY AIR MAIL

685. T. Y. Tien

University of Michigan

Materials Science and

Engineering Department

Dow Building

Ann Arbor, MI 48103

686. Julian M. Tishkoff

Air Force Office of Scientific Research

AFOSR/NA

Bolling AFB, DC 20332-6448

687. D. M. Tracey

Norton Company

Advanced Ceramics

Goddard Road

Northboro, MA 01532-1545

688. Dick Trippett

General Motors Corporation

Allison Gas Turbine Division

P.0. Box 4co, MS:W-16

Indianapolis, IN 46206-0420 
689. L. J. Trostel, Jr.

Box 199

Princeton, MA 01541

690. W. T. Tucker

General Electric Company

Corporate R\&D

Building K1-4C35

P.0. Box 8

Schenectady, NY 12301

691. Masarori Ueki

Nippon Steel Corporation

Central R\&D Bureau

1618 Ida

Nakahara-Ku Kawasaki 2\$1

JAPAN AIR MAIL.

692. Filippo M. Ugolini

ATA Studio

Via Degii Scipioni, 268A

ROMA 00192

ITALY AIR MAIL

693. Donald L. Vaccari

Allison Gas Turbines

P.0. Box 420

Speed Code $\$ 49$

Indianapolis, IN 46206-0420

694. Carl F. Van Conant

Boride Products, Inc.

2879 Aero Park Drive

Traverse City, MI 49684

695. Marcel H. Van De Voorde

Commission of the European Communities

Institute for Advanced

Materials

Joint Research Centre

P.0. Box 2

1755 ZG Petten

THE NETHERLANDS AIR MAIL

696. 0. Van Der Biest

Katholieke Universiteit Leuven

Departement Metaalkunde en Toegepaste

de Croylaan 2

B-3030 Leuven

BELGIUM AIR MAIL
697. Michael Vannier

Washington University, St. Louis

Mall inckrodt Institute of Radiology

510 South Kings Highway

St. Louis, MO 63110

698. Stan Venkatesan

Southern Coke \& Coar Corporation

P.0. Box 52383

Knoxvi'le, TN 37950

699. V. Venkateswaran

Carborundum Company

Niagara Falls R\&D Center

P.0. Box 832

Niagara Falls, NY 14302

700. Dennis Viechnicki

U.S. Army Materials Technology Laboratory

405 Arsenal Street

Watertown, MA 02172-0001

701. Ted Vojnovich

U.S. Department of Energy

Office of Energy Research, ER-42

Washington, DC 20585

702. John D. Volt

E. I. Dupont de Nemours \& Company, Inc.

P.O. Box 80262

Wilmington, DE 19880

703. John B. Wachtman

Rutgers University

Ceramics Department

P.0. Box 909

Piscataway, NJ 08855

704. Shigetaka Wada

Toyota Central Research Labs, Inc.

Nagakute Aichi 480-11

JAPAN AIR MAIL 
705. Janet Wade

Allied-Signal Aerospace Company

Garrett Auxiliary Power Division, Department 93-772

P.0. Box 5227, MS: $1303-2$

Phoenix, AZ 85010

706. Richard L. Wagner

Ceramic Technologies, Inc.

537 Turtle Creek South Drive, Suite 240

Indianapolis, IN 46227

707. J. Bruce Wagner, Jr.

Arizona State University

Center for Solid State Science

Tempe, AZ 85287-1704

708. Daniel J. Wahlen

Kohler, Co.

$444 \mathrm{Highl}$ and Drive

Kohler, WI 53044

709. Ingrid Wahigren

Royal Institute of Technology

Stuasvik Library

S-611 82 Nykoping

SWEDEN AIR MAIL

710. Ron $\mathrm{H}$. Walecki

Allied-Signal Aerospace Company

Garrett Ceramic Components Division

19800 South Van Ness Avenue

Torrance, CA 90501

711. Michael S. Walsh

Vapor Technologies Inc.

2100 Central Avenue

Boulder, CO 80301

712. Chien-Min Wang

Industrial Technology Research Institute

Materials Research Laboratories

195 Chung-Hsing Road, Sec. 4

Chutung Hs inchu 31015 R.0.C.

TAIWAN AIR MAIL
713. Robert M. Washburn

ASMT

11203 Colima Road

Whittier, CA 90604

714. Gerald Q. Weaver

Carborundum Specialty Products

42 Linus Allain Avenue

Gardner, MA 01440-2478

715. Karen E. Weber

Detroit Diesel Corporation

Technology and Planning

13400 West Outer Drive

Detroit, MI 48239-4001

716. R. W. Weeks

Argonne National Laboratory

MCT-212

9700 South Cass Avenue

Argonne, IL 60439

717. Ludwig Weiler

ASEA Brown Boveri AG

Corporate Research

Eppelheimer Str. 82

D-6900 Heidelberg

GERMANY AIR MAIL

718. James Wessel

Dow Corning Corporation

1800 "M" Street, N.W., Suite 325 South

Washington, DC 20036

719. Robert D. West

Therm Advanced Ceramics

P. 0. Box 220

Ithaca, NY 14851

720. Thomas J. Whalen

Ford Motor Company

26362 Harriet

Dearborn Heights, MI 48127

721. Ian A. White

Hoeganaes Corporation

River Road

Riverton, NJ 08077 
722. Alan Whitehead

General Electric Company

1 River Road, 55-111

Schenectady, NY 12345

723. Sheldon M. Wiederhorn

National Institute of

Standards and Technology

Building 223, Room A329

Gaithersburg, MD 20899

724. John F. Wight

Alfred University

McMahon Building

Alfred, NY 14802

725. D. S. Wilkinson

McMaster University

Materials Science and

Engineering Department 1280 Main Street, West Hamilton Ontario L8S 4L7 CANADA AIR MAIL

726. James C. Williams

General Electric Company

Engineering Materials Technology Labs

One Neumann Way

Mail Drop: $\mathrm{H85}$

Cincinnat $i$, OH 45215-6301

727. Janette R. Williams

Kollmorgen Corporation

PCK Technology Division

150 Motor Parkway, \# 262

Hauppauge, NY 11788-5108

728. Steve J. Williams

RCG Hagler Bailly, Inc.

1530 Wilson Boulevard, Suite 900

Arlington, VA 22209-2406

729. Craig A. Willkens

Norton Company

Advanced Ceramics

Goddard Road

Northboro, MA 01532-1545
730. Roger R. Wills

TRW, Inc.

Valve Division

1455 East 185th Street

Cleveland, $\mathrm{OH} 44110$

731. David Gordon Wilson

Massachusetts Institute of Technology

Mechanical-Engineering Department

77 Massachusetts Avenue, Room 3-455

Cambridge, MA 02139

732. Mat thew F. Winkler

Seaworthy Systems, Inc.

P.0. Box 965

Essex, CT 06426

733. Gerhard Winter

Hermann C. Starck Berlin GmbH, Werk Goslar

P.0. Box 2540

D-3380 Gosiar 3380

GERMANY AIR MAIL.

734. W. L. Winterbottom

Ford Motor Company

Material Systems Reliability Department

20000 Rotunda Drive

SRL, Room E-3182

P.0. Box 2053

Dearborn, MI 48121

735. David G. Wirth

Coors Ceramics Company

600 9th Street

Golden, CO 80401

736. Thomas J. Wissing

Eaton Corporation

Engineering \& Research Center

P.0. Box 766

Southfield, MI 48037

737. James C. Withers

MER Corporation

7960 South Kolb Road

Building $F$

Tucson, AZ 85706 
738. Dale E. Wittmer

Southern Illinois University

Mechanical Engineering Department

Carbondale, IL 62901

739. Warren W. Wolf

Owens Corning Fiberglass

2790 Columbus Road, Route 16

Granville, OH 43023

740. George W. Wolter

Howmet Turbine Components

Corporation

Technical Center

699 Benston Road

Whitehall, MI 49461

741. James C. Hood

NASA Lewis Research Center

21000 Brookpark Road

MS:86-6

Cleveland, $\mathrm{OH} 44135$

742. Marrill Wood

LECO Corporation

Augusta Division

P.0. Box 211688

Augusta, GA 30917-1688

743. Wayne L. Worrell

University of Pennsylvania

Department of Materials

Science and Engineering

3231 Walnut Street

Philadelphia, PA 19104

744. John F. Wosinski

Corning Inc.

ME-2 E-5 H8

Corning, NY 14830

745. Ian G. Wright

Battelle Columbus Laboratories 505 King Avenue

Columbus, $\mathrm{OH} 43201$

746. Ruth Wroe

ERDC

Metals \& Materials Industries

Division

Capenhurst Chester $\mathrm{CHI}$ 6ES

ENGLAND AIR MAIL
747. Bernard J. Wrona

Advanced Composite Materials

Corporation

1525 South Buncombe Road

Greer, SC 29651

748. Cart C. M. Wu

Naval Research Laboratory

Ceramic Branch, Code 6373

Washington, - DC 20375

749. John C. Wurst

University of Dayton Research Institute

300 College Park

Dayton, OH 45469-0101

750. Neil Wyant

ARCH Development Corp.

9700 South Cass Avenue

Building 202

Argonne, IL 60439

751. Roy Yamamoto

Texaco Inc.

P.0. Box 509

Beacon, NY 12508-0509

752. John Yamanis

Allied-Signal, Inc.

Ceramics Program

P.0. Box 1021

Morristown, NJ 07962-1021

753. Harry C. Yeh

Allied-Signal Aerospace

Company

Garrett Ceramic Components Division

19800 South Van Ness Avenue

Torrance, CA 90509

754. Hiroshi Yokoyama

Hitachi Research Lab

$4026 \mathrm{Kuji-Cho}$

Hitachi-shi Ibaraki 319-12

JAPAN AIR MAIL

755. Thomas M. Yonushonis

Cummins Engine Company, Inc.

P.0. Box 3005

Mail Code 50183

Columbus, IN 47202-3005 
756. Thomas J. Yost

Corning, Inc.

Technical Products Division, Main Plant 21-1-2

Corning, NY 14831

757. Jong Yung

Sundstrand Aviation Operations

Department 789-6

4747 Harrison Avenue

Rockford, IL 61125

758. A. L. Zadoks Caterpillar Inc.

Technical Center, Building L P.0. Box 1875

Peoria, IL 61656-1875

759. Avi Zangvil

University of Illinois

Materials Research Laboratory

104 South Goodwin Avenue

Urbana, IL 61801

760. Charies H. Zenuk

Transtech

6529 East Calle Cavalier

Tucson, AZ 85715

761. Anne Marie Zerega

U.S. Department of Energy

Office of Energy Research, ER-42

Washington, DC 20585

762. Ken Zillmer

Applied Test Systems, Inc.

2571 Mt. Gallant Road

Rock Hill, SC 29730

763. Carl Zweben

General Electric Company

P.0. Box 8555, VFSC/V4019

Philadelphia, PA 19101

764. Klaus M. Zwilsky

National Research Council

National Materials

Advisory Board

2101 Constitution Avenue

Washington, DC 20418
765. Department of Energy

DOE Field Office, Oak Ridge

Assistant Manager for Energy Research and Development

P.0. Box 2001

Oak Ridge, TN 37831-8501

766-775. Department of Energy

Office of Scientific and Technical Information

office of Information Services

P.0. Box 62

Dak Ridge, TN 37831

For distribution by microfiche as shown in DOE/OSTI-4500, Distribution Category UC-332 (Ceramics/Advanced Materials). 

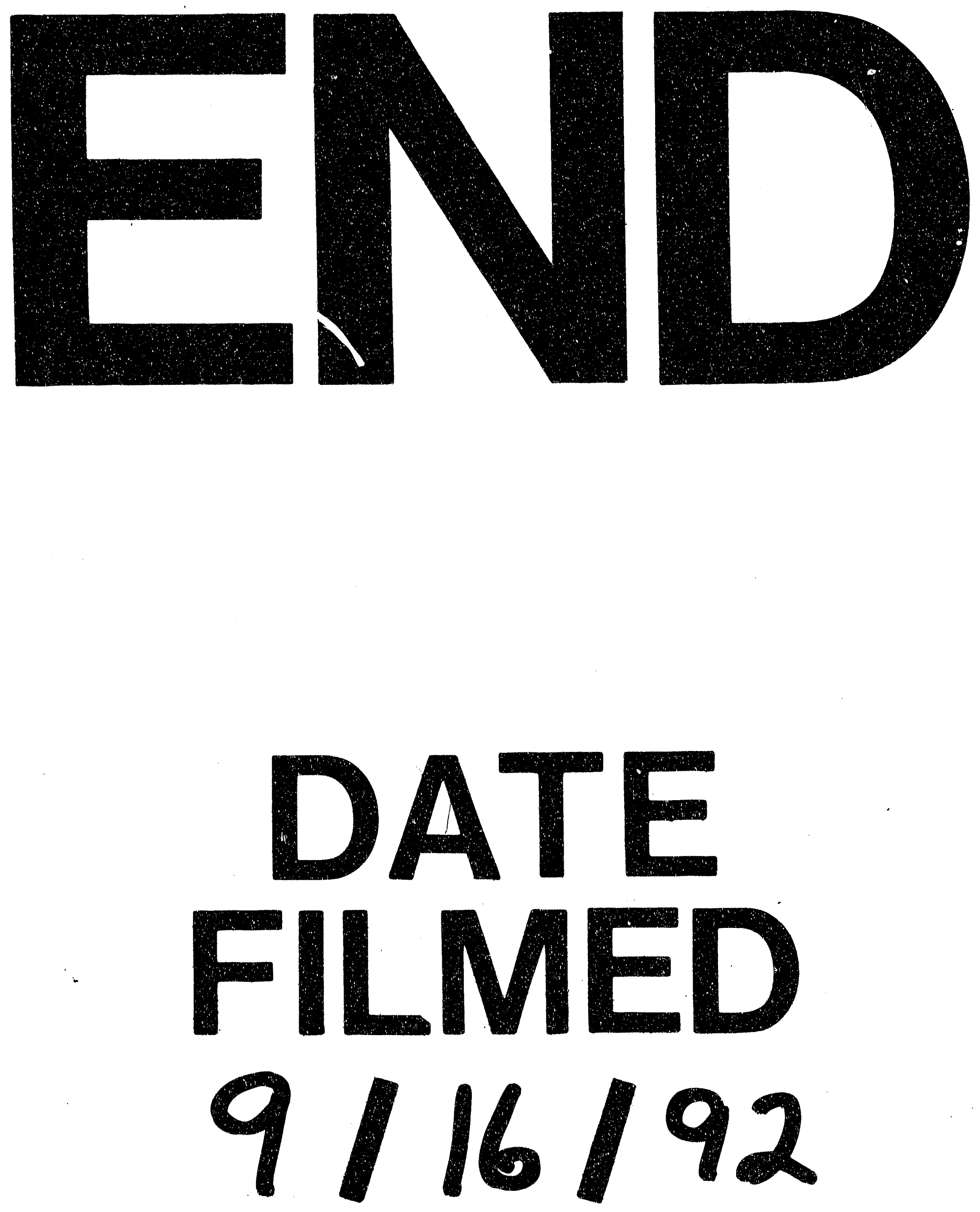


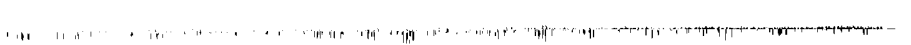

